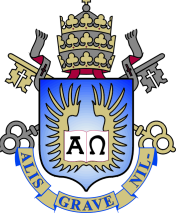

Bernardo Barboza Ribeiro

Politics of government advertising: evidence from Brazil

Dissertation presented to the Programa de Pós-graduação em Economia of PUC-Rio in partial fulfillment of the requirements for the degree of Mestre em Economia.

Advisor: Prof. Claudio Abramovay Ferraz do Amaral 


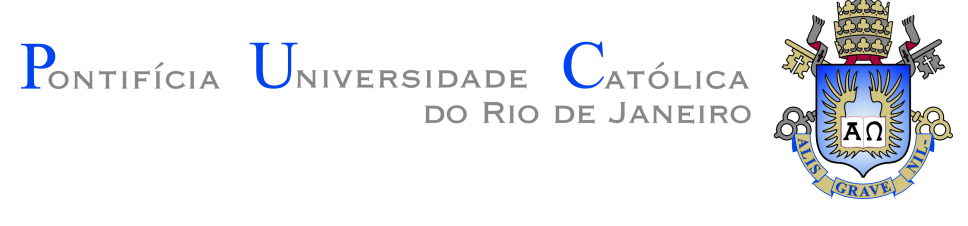

\section{Bernardo Barboza Ribeiro}

\section{Politics of government advertising: evidence from Brazil}

Dissertation presented to the Programa de Pós-graduação em Economia of PUC-Rio in partial fulfillment of the requirements for the degree of Mestre em Economia. Approved by the undersigned Examination Committee.

Prof. Claudio Abramovay Ferraz do Amaral

Advisor

Departamento de Economia - PUC-Rio

Prof. Juliano Junqueira Assunção

Departamento de Economia - PUC-Rio

Prof. Raphael Bottura Corbi

Faculdade de Economia e Administração - USP

Prof. Monica Herz

Dean of Graduate Studies

Centro de Ciências Sociais - PUC-Rio

Rio de Janeiro, March 27th, 2017 
All rights reserved.

\section{Bernardo Barboza Ribeiro}

B.A., Economics, Pontifícia Universidade Católica do Rio de Janeiro (PUC-Rio), 2014.

Ficha Catalográfica

Barboza Ribeiro, Bernardo

Politics of government advertising: evidence from Brazil / Bernardo Barboza Ribeiro; orientador: Claudio Abramovay Ferraz do Amaral. - 2017.

v., 104 f: il. color. ; $30 \mathrm{~cm}$

Dissertação (mestrado) - Pontifícia Universidade Católica do Rio de Janeiro, Departamento de Economia.

Inclui bibliografia

1. Economia - Teses. 2. Propaganda governamental;. 3. Economia política;. 4. Eleições presidenciais;. 5. Política de distribuição;. 6. Rádio;. I. Ferraz, Claudio. II. Pontifícia Universidade Católica do Rio de Janeiro. Departamento de Economia. III. Título. 


\section{Acknowledgments}

I would like to thank my parents, Marta and Antonio, for all the support. I thank my advisor, Claudio Ferraz, for the guidance given to me through all this period. I am also thankful for all the support given by my friends. Financial support from $\mathrm{CNPq}$ is gratefully acknowledged. 


\section{Abstract}

Barboza Ribeiro, Bernardo; Ferraz, Claudio (Advisor). Politics of government advertising: evidence from Brazil. Rio de Janeiro, 2017. 104p. Dissertação de Mestrado - Departamento de Economia, Pontifícia Universidade Católica do Rio de Janeiro.

Using a unique data set of central government expenditure on advertising in Brazil, we shed light on the behavior of public advertisers and the relation between government ads and voting. In particular, we investigate political motivations behind the allocation of the advertisement budget by the federal government and its impacts on voting. Borrowing insights from the literature of distributive politics, we first correlate ad money and votes for the government's party on the local level. Next, we exploit plausible exogenous variation on radio signal coverage to test if money spent on ads turn into votes for the government's party. Our findings show that although past presidential election outcomes predict where in the territory the government places ads, voters do not seem to be persuaded by those ads to favor the party in power.

\section{Keywords}

Government advertising; Political Economy; Presidential elections; Distributive politics; Radio; 


\section{Resumo}

Barboza Ribeiro, Bernardo; Ferraz, Claudio. Política e proganda: evidência do Brasil. Rio de Janeiro, 2017. 104p. Dissertação de Mestrado - Departamento de Economia, Pontifícia Universidade Católica do Rio de Janeiro.

Usando uma base de dados inédita com informações sobre o gasto do governo federal brasileira com propaganda, nós lançamos luz sobre o comportamento de anunciantes do setor público a relação entre propaganda governamental e voto. Em particular, nós investigamos possíveis motivações políticas por trás da alocação do orçamento dedicado à propaganda governamental e seu impacto sobre voto. No espírito da literatura de distributive politics, primeiro nós calculamos a correlação entre gasto com anúncios por entes públicos e votos no partido do governo no nível local. Em seguida, nós exploramos a variação exógena gerada pela cobertura de sinais de rádio para testar a hipótese de que o gasto com propaganda aumenta os votos recebidos pelo partido do governo. Nossos resultados sugerem que, ainda que resultados de eleições passadas prevêem onde no território o governo anuncia, os eleitores não parecem ser persuadidos pelos anúncios a votar em favor do partido no poder.

\section{Palavras-chave}

Propaganda governamental; Economia política; Eleições presidenciais; Política de distribuição; Rádio; 


\section{Table of contents}

1 Introduction $\quad 12$

\begin{tabular}{ll}
2 & Institutional Background \\
\hline
\end{tabular}

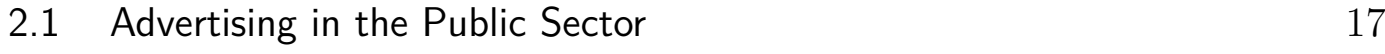

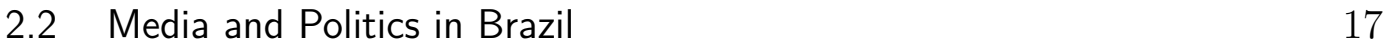

3 Data $\quad 19$

3.1 Government Advertisement Spending 19

3.2 Municipality Level Data 20

3.3 Polling Station Level Data 22

3.3.1 Radio Coverage $\quad 22$

$4 \quad$ Government Advertisement and Past Voting $\quad 31$

4.1 Empirical Strategy 31

4.2 Results 32

4.3 Spending on Election Years 34

5 Does Advertisement Affect Voters? Evidence from Radio 41

5.1 Empirical Strategy 41

5.2 Main Results 43

5.3 Robustness Checks 44

$\begin{array}{lll}6 & \text { Conclusion } & 48\end{array}$

$\begin{array}{ll}\text { A Appendix } & 54\end{array}$

$\begin{array}{lll}\text { B Appendix } & 58\end{array}$

C Appendix $\quad 64$ 


\section{List of figures}

3.1 Total federal government spending on ads: 2000-2015 24

3.2 Federal government spending on ads, by entity type: 2000-2015 24

3.3 Federal government spending on ads, by media type: 2000-2015 25

3.4 Spending per capita (2003-2014, excluding TV), capital centroids in red

3.5 FM and AM radio stations 29

3.6 2014 Polling stations and radio coverage 30

A1 Government advertising data $\quad 54$

A2 Ad sample: Ministry of Education $\quad 54$

A3 Ad sample: Caixa $\quad 55$

A4 Mean and median contract values, all media: 2000-2015 56

A5 TV mean and median contract values: 2000-2015 56

A6 Printed, radio and web mean and median contract values: 2000-2015 57

A7 Spending on revenue top 10 ad agencies: 2000-2015 57

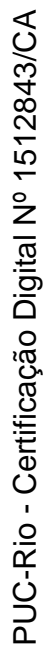

C1 Ads on voting: empirical strategy illustration 64 


\section{List of tables}

3.1 Characteristics of the municipalities where media vehicles chosen to receive advertising money are located at 26

3.2 City ranking 26

$\begin{array}{lll}3.3 & \text { Summary statistics } & 27\end{array}$

4.1 Spending per capita (exc. TV) on cycle after the election: total 35

4.2 Spending per capita (exc. TV) on cycle after election: by entity type 36

4.3 Spending per capita (exc. TV) on cycle after election: by entity type 37

4.4 Spending per capita (exc. TV) on cycle after election: by media type 38

4.5 Spending per capita (exc. TV) on cycle after election: by media type 39

4.6 Spending per capita (exc. TV) on cycle after election: by media type 40

5.1 Polling station characteristics: balance test. Control group: no signal within $5 \mathrm{~km} \quad 46$

5.2 Impact of ads on voting: main specifications 47

B1 Spending per capita (exc. TV) on election year: total 58

B2 Spending per capita (exc. TV) on election year: by entity type $\quad 59$

B3 Spending per capita (exc. TV) on election year: by entity type 60

B4 Spending per capita (exc. TV) on election year: by media type 61

B5 Spending per capita (exc. TV) on election year: by media type 62

B6 Spending per capita (exc. TV) on election year: by media type 63

C1 Polling stations characteristics: balance test. Control group: no signal within $10 \mathrm{~km}$

C2 Polling stations characteristics: balance test. Control group: no signal within $15 \mathrm{~km} \quad 66$

C3 Polling stations characteristics: balance test. Control group: no signal within $20 \mathrm{~km}$

C4 Polling stations characteristics: balance test. Control group: no signal within $25 \mathrm{~km}$

C5 Polling stations characteristics: balance test. Control group: no signal within $30 \mathrm{~km}$

C6 Polling stations characteristics: balance test. Control group: no signal within $40 \mathrm{~km}$

C7 Polling stations characteristics: balance test. Control group: no signal within $50 \mathrm{~km}$

C8 Polling stations characteristics: balance test. Control group: nonsponsored signal within $5 \mathrm{~km}$

C9 Polling stations characteristics: balance test. Control group: nonsponsored signal within $10 \mathrm{~km}$

C10 Polling stations characteristics: balance test. Control group: nonsponsored signal within $15 \mathrm{~km}$

C11 Polling stations characteristics: balance test. Control group: nonsponsored signal within $20 \mathrm{~km}$ 
C12 Polling stations characteristics: balance test. Control group: nonsponsored signal within $25 \mathrm{~km}$

C13 Polling stations characteristics: balance test. Control group: nonsponsored signal within $30 \mathrm{~km}$

C14 Polling stations characteristics: balance test. Control group: nonsponsored signal within $40 \mathrm{~km}$

C15 Polling stations characteristics: balance test. Control group: nonsponsored signal within $50 \mathrm{~km}$

C16 Polling stations characteristics: balance test. Control group: nonsponsored signal or no signal within $5 \mathrm{~km}$

C17 Polling stations characteristics: balance test. Control group: nonsponsored or no signal within $10 \mathrm{~km}$

C18 Polling stations characteristics: balance test. Control group: nonsponsored or no signal within $15 \mathrm{~km}$

C19 Polling stations characteristics: balance test. Control group: nonsponsored or no signal within $20 \mathrm{~km}$

C20 Polling stations characteristics: balance test. Control group: nonsponsored or no signal within $25 \mathrm{~km}$

C21 Polling stations characteristics: balance test. Control group: nonsponsored or no signal within $30 \mathrm{~km}$

C22 Polling stations characteristics: balance test. Control group: nonsponsored or no signal within $40 \mathrm{~km}$

C23 Polling stations characteristics: balance test. Control group: nonsponsored or no signal within $50 \mathrm{~km}$

C24 Polling stations that get any sponsored signal. Control group: polling stations that get non-sponsored signal

C25 Polling stations that get any sponsored signal. Control group: polling stations that get no signal

C26 Polling stations that get any sponsored signal. Control group: polling stations that get non-sponsored or no signal

C27 Polling stations that get sponsored signal from other municipality. Control group: polling stations that get non-sponsored signal

C28 Polling stations that get sponsored signal from other municipality. Control group: polling stations that get no signal

C29 Polling stations that get sponsored signal from other municipality. Control group: polling stations that get non-sponsored or no signal

C30 Polling stations that get any sponsored signal and how many signals get. Control group: polling stations that get non-sponsored signal.

C31 Polling stations that get any sponsored signal and how many signals get. Control group: polling stations that get no signal.

C32 Polling stations that get any sponsored signal and how many signals get. Control group: polling stations that get non-sponsored or no signal.

C33 Polling stations that get sponsored signal from other municipality and how many signals get. Control group: polling stations that get non-sponsored signal. 
C34 Polling stations that get sponsored signal from other municipality and how many signals get. Control group: polling stations that get no signal.

C35 Polling stations that get sponsored signal from other municipality and how many signals get. Control group: polling stations that get non-sponsored or no signal.

C36 Polling stations that get any sponsored signal and how much is spent per capita. Control group: polling stations that get nonsponsored signal.

C37 Polling stations that get any sponsored signal, how much is spent per capita. Control group: polling stations that get no signal.

C38 Polling stations that get any sponsored signal and how much is spent per capita. Control group: polling stations that get nonsponsored or no signal.

C39 Matching: polling stations that get any sponsored signal, all control groups and distances

C40 Matching: polling stations that get sponsored signal from other municipality, all control groups and distances 


\section{Introduction}

Many governments around the world spend significant amounts of money on advertisement campaigns and propaganda. ${ }^{1}$ Government advertising campaigns may be useful to inform citizens on issues of public interest (e.g. vaccination campaigns), but it may also accentuate incumbency advantage and reduce political competition.

In this paper, we examine the role played by electoral incentives in advertising decisions and whether advertising affects voting patterns. The exercises we propose help us to distinguish pure informative strategy when the government places ads from worrisome electoral motivations. Considering Brazil's case, where the federal government spends a relevant amount of resources on advertising through ministries and public companies, we assemble a unique data set of central government expenditure on advertising and shed light on the behavior of public advertisers and its impact on voters. We find that the incumbent party in the presidency spends more money where it received fewer votes in the past, but this strategy does not seem to persuade voters to support the government in ballots.

Borrowing insights from the literature on distributive politics, we first regress ad money and votes in the local level using the period in which $\mathrm{PT}$, the Brazilian worker's party, was in power. We show that (past) presidential election outcomes predict where in the territory the government places ads. In particular, this relation is negative and statistically significant, which suggests that the lower the PT share of votes in a given municipality in a given election year, more money is poured into subsequent years. The relation is stronger when taking into account only money poured by ministries (compared to public

\footnotetext{
${ }^{1}$ Media vehicles and civic and political organizations frequently contest the goals of government advertising campaigns and their content. The Washington Post once called government advertising spending a "black box". See "Public relations and advertising are a 'black box' in government spending", October $14^{\text {th }}, 2014$. Similar claims have been made in other countries, such as India, Australia, and United Kingdom. In 2016, the Indian Congress contested the federal government on campaigns featuring the Prime Minister Narendra Modi. See India Today, "Union government spent over Rs 1,100 crore on advertisements featuring PM Modi, reveals RTI query", November $29^{\text {th }}$, 2016. See The Guardian on UK's ad campaigns, "Government ad spend to increase by $22 \%$ to almost $£ 300 \mathrm{~m}$ ", May $14^{\text {th }}$, 2014. See The Australian on Australia's ad campaigns, "Cutbacks in government advertising spending save $\$ 60 \mathrm{~m} "$, December $30^{\text {th }}, 2014$.
} 
companies). This is compatible with public companies trying to maximize profits and ministries being more subject to political influence. Finally, the association is also stronger when taking into account the money poured into low range media, such as radio (compared to TV etc.). This is compatible with a situation in which the federal government wants to gather votes locally using ads, as low range media, such as radio, not TV, are probably more suitable for that.

Next, we assess the causal impact of federal government spending on ads on voting by exploiting exogenous variation associated with the geography of radio coverage. We compare polling stations close enough to each other, one that did and other(s) that did not receive FM radio signal from a station sponsored by the government. Using different specifications for the treatment status, we show that it does not seem to be the case that advertising spending induces individuals to vote for the government.

Although we don't provide evidence on that, the probable mechanism through which government tries to persuade voters is by pouring money into media vehicles to induce bias in content. Since the government ads we have data on are mostly institutional or ran by public companies, we believe the ad content itself is unlikely to carry pro-government information.

Our work is related to different broader literatures in Economics and Political Science. First, when describing how ad money is spent across space and time, we borrow insights from the literature of distributive politics. In a vast literature review, (1) define distributive policies as "those that involve taxes and transfers, and in particular the decisions about allocations of government goods and services to identifiable localities or groups". We can think of those policies as decisions taken by elected representatives to provide goods or services to voters of a specific region in the country's territory. In this literature, one question is particularly relevant: do elected representatives allocate resources targeting their local bases, in which their support is greater (core voters), or do they target places where the fight for votes seems to be tougher (swing voters)? Several papers have built models that help answering this question, such as (2), (3), (4) and the political competition under special interest politics in (5).

An immediate implication of this family of models is that, once the candidates must direct more resources to get less aligned voters, the parties will naturally dispute moderate or "swing" voters. However, sometimes parties may allocate goods and services to core voters. It happens when one party has more information about the electorate than the other party and, thus, is more capable of precisely targeting the resources to those voters $((2))$. In this case, 
targeting resources to swing voters becomes inefficient: candidates do not hold detailed information on voters and some citizens end up not receiving enough resources to change their votes.

Based on this theoretical framework, several studies try to answer empirically the question on core supporter vs. swing voters. ${ }^{2}$ Among several empirical studies on distributive politics, there is no established answer to support only one of the two hypotheses mentioned. (7), for instance, show that marginal constituencies ran by opposition parties received more money from the central government in England, which leads the authors to argue in favor of the swing voter hypothesis. On the other hand, (8) provide evidence on the core supporter hypothesis by observing that the central government in India targets money to aligned states. In a similar framework, (9) study government responsiveness and analyze empirically the case of India. The authors argue that state governments respond more to falls in food production and crop flood damage via public food distribution and calamity relief expenditure where newspaper circulation is higher and electoral accountability greater.

The goal of our first exercise is to calculate a broad, spatial association between government spending on ads and past votes. In contrast to what is typically done in the literature of distributive politics, which studies the allocation of identifiable public goods and services, public jobs etc. having in mind redistribution outcomes, in our paper we study the allocation of advertising money. There reside some important differences. For instance, an important instrument identified by the literature through which the federal government was able to gather votes in Brazil is the country's biggest Conditional Cash Transfer (CCT) program, Bolsa Família. Bolsa Família is aimed at families in situation of poverty and extreme poverty and benefits more than $20 \%$ of the entire population. When evaluating the impact of this CCT program on incumbent party presidential candidates, (10) argues that the program boosts these candidates' performance, although this effect is reaped among candidates of other parties too.

In Brazil, Bolsa Família involves a sizable amount of resources to be distributed among citizens. However, the total amount spent by the Brazilian federal government in 2009-2015 corresponded to less than 10 percent of Bolsa Família. Moreover, Brazil has nearly 100 million voters and 5500 municipalities, so the potential redistribution in terms of resources spent by the federal government on advertisement is probably not very large.

${ }^{2}$ The models are based on individual voters, but the data are usually available in a more aggregated level, typically in the electoral district or constituency level. The hypothesis to be tested, then, involves core versus swing constituencies, not voters. This subtle difference ends up favoring the swing voter hypothesis. See (6). 
Our work differs from the pork barrel politics literature that studies the behavior of voters when rewarding or not past performance by politicians. In our case, there is no clear redistribution towards groups of voters when choosing where to place ads, as the electorate only gets the information that the ad campaign carries. However, the inspiration contained in our first argument is similar to those papers if we imagine the government wants some groups of voters to get specific information that may persuade them into voting for the incumbent party. If that is the case, the natural question to be answered next is whether advertising allocation actually affects voters.

In our second exercise, we estimate the causal impact of advertising on voter behavior. As we will argue, persuasion is the likely channel through which advertising affects voting. When estimating this effect, our paper relates closely to the literature on persuasion (see (11)) and, in particular, to papers that study media persuasion and media bias. For instance, our work is tied to articles that estimate TV and radio impact on voter behavior ((12), (13)). We contribute to the literature concerned about incumbent power and media bias too $((14))$.

Our work is also related to the literature that studies the role of advertisers in the media sector and their impact on media bias. In a canonical model, (15) predict that greater (private) advertisement potential of a media vehicle is associated with lower risk of media capture. (16) argues that large advertising potential reduces bias, but this can increase the probability of nationalization of private media vehicles by the government. On the empirical side, there are a few relevant works on the interaction between private ads, media bias and politics. Di (17), for example, document an interesting lobbying channel, by which firms shift spending on ads towards a politician's business in the hope of securing favorable regulation. (18) study a more direct channel, advertising by political parties, and find that it does not induce bias in newspaper coverage.

When modeling the possible mechanisms through which private advertisers may induce media bias, apart from the world of politics, (19) argue, in line with (15), that advertising can raise accuracy by increasing the intensity of competition for readers, who in the model value the accuracy of news. However, it may be also the case that the media does not reach full accuracy if advertisers are able to commit to withdrawing advertising from newspapers that are very accurate on sensitive issues. (20) and (21) study the interaction between firms and media vehicles and document coverage bias towards private advertisers. Di (22) and (19) present the mechanism we argue is in place in Brazil: the money poured by the government in media vehicles are crucial for 
financing them and this induces bias.

Most of the literature presented above, however, is mute about the government as an advertiser. Two recent papers study government advertising empirically. Di (22) document a strong negative association between the amount of government advertising and coverage of corruption scandals by Argentinian newspapers. (23) study the Hungarian case and show that, under right-wing governments, state-owned firms direct advertising money to lowcirculation right-connected media, providing evidence of (indirect) political favoritism operating through the advertisement channel. As mentioned before, the mechanism we have in mind operates through media financing. But unlike Di (22), we are not able to point this out empirically because we don't observe media content. We cannot either say anything about media alignment or ideology, as (23) do. Instead, here we are interested in the impact of advertising on voters.

Finally, our empirical strategy is closely related to that of (24), which exploits geographic variation made available by radio technology to show that signal availability of Serbian station across the border with Croatia triggers higher voting on extreme, nationalist parties by Croats. Similarly, (25) argues that a radio station in Rwanda played an important role in disseminating hate speech and mobilizing people to promote violence.

The remaining of this work is organized as follows. In Section 2 we present the institutional background on how the Brazilian federal government places ads, briefly describing the media landscape, its relation to politics and the political system in Brazil. Section 3, we present the data we use throughout both exercises we do. In Sections 4 and 5, we present the empirical strategy and the results of each one of the exercises we propose. Section 6 concludes. 


\section{2}

\section{Institutional Background}

Before presenting our data and moving on to the empirical strategy and results, it is worth describing the institutional framework of the public sector as an advertiser in Brazil.

\section{1}

\section{Advertising in the Public Sector}

The Brazilian federal government as a unique advertiser, i.e., considering together all the money spent on ads by ministries, public companies etc., ranks first in the country. ${ }^{1}$ As typically occurs in the private sector, the ad contracts in the Brazilian public sector are signed by advertisers with private ad agencies, which in turn produce the campaigns and negotiate price conditions with the media vehicles directly. And as typically occurs in the public sector, public advertisers hire agencies based on public procurement. ${ }^{2}$ Media vehicles disclose public price menus, but those are rarely the actual prices paid. Normally, the ad agency negotiates a discount, which is private information of both the agency and the media vehicle. The discounts depend mostly on the vehicle (discounts are usually lower for higher audience vehicles), but probably vary across agencies and advertisers too (there may be also quantity discounts). The agencies earn money through commission (e.g. $20 \%$ of total contract value) or fees (e.g. amount per campaign, fixed or according to the audience).

\section{2}

\section{Media and Politics in Brazil}

Unlike countries such as Russia, for instance, the media sector in Brazil, as in Latin America in general, is mostly dominated by privately owned companies. A few private TV networks get almost all audience and TV Globo is the most prominent player. As private media vehicles, radio stations in

${ }^{1}$ In 2015, according to Kantar Ibope Media, a company that monitors ad spending in Brazil. See www.kantaribopemedia.com/anunciantes-2015.

${ }^{2}$ Until 2010, this was done under the Federal Procurement Law 8666/93, which regulates public procurement in Brazil. Since 2010, ad contracts are signed under the regulation of Federal Law 12232/2010, specific to this purpose and which is now more precise on the technical requirements of ad campaigns. 
Brazil depend heavily on ad revenues. ${ }^{3}$ And, in the local level, politicians are remarkably known as owners of radio stations, for instance [see (26) for a broad description of the media sector in Latin America].

In this context, it is natural to see that the media plays an important role in Brazilian politics. Radio was already shown to be both an important tool to promote accountability and an asset desired by politicians to win elections. (27) report that voters punish corrupt incumbent more severely when a local radio station is available to divulge information. On the other hand, the ownership of media vehicles is an asset when disputing elections. (28) argue that incumbency increases sharply the probability that a politician gets a radio license approved and (28) and (29) show that the ownership of a local radio or TV station boosts the probability of winning an election. It is also known that TV plays an important role in elections in Brazil. (30) study the impact of TV advertising campaigns on election outcomes. They conclude, for gubernatorial races, that higher shares of TV time increases a candidate's vote share.

${ }^{3}$ See a survey conducted by the National Association of Radio Stations in 2014 at http://www.abert.org.br/site/index.php/dados-do-setor/estatisticas/faturamento-do-setor. 


\section{Data}

\section{1}

\section{Government Advertisement Spending}

The Instituto para Acompanhamento da Publicidade (IAP), founded in 1997 and held by ad agencies and public advertisers, documents all pedidos de inserção (PI) or "insertion requests", made by all federal entities to place ads on any media, and sends this information to the Secretaria de Comunicação Social da Presidência da República (SECOM), the Secretary responsible for Presidency Communications, that tabulates the data.

Data on the amount spent by the Brazilian federal government were made available through the Lei de Acesso à Informação, the law in Brazil analogous to the US Freedom of Information Act. ${ }^{1}$ It allows us to track the amount (current value) spent per year by each federal entity that advertised, and where these public advertisers placed its ads in the period of 2000-20152. Public entities are public companies, secretaries, ministries, among others. Just like private companies, those entities run ad campaigns on the TV, newspapers, magazines, internet and other types of media vehicles (see Figure A1 for a visual description of the data). ${ }^{3}$

In 2000, the federal government, via its multiple entities, spent nearly USD 500 millions in ads, compared to almost USD 900 millions in 2013. Due to fiscal adjustments, this amount dropped to approximately USD 600 millions in 2015 (see Figure 3.1). Almost $70 \%$ of the amount was spent by public companies and the remaining was mainly spent by ministries and secretaries (see Figure 3.2). In 2015, 3 out of the top 10 advertisers in Brazil were public companies. Taking together all its entities, the federal government was the greatest advertiser in Brazil this year. By media type, almost $60 \%$ of all spending was on TV. As expected, the vast majority of ads are placed by the five main public companies in Brazil, namely Petrobras, Correios (postal

${ }^{1}$ We would like to thank journalist Fernando Rodrigues, now in Poder360, for sharing the data and his assistant, Mateus Netzel, for all the help.

${ }^{2}$ Our data does not cover money spent on sponsorship deals, such as those involving Caixa and soccer teams, for instance.

${ }^{3}$ In Appendix A, we show sample ads placed by the federal government in a newspaper and in a magazine. 
office), BNDES, Banco do Brasil and Caixa (the 3 main public banks in Brazil). In 2000 , spending on printed media corresponded to almost $40 \%$ of the total amount, but this share has been declining over time, as the share spent on the internet has grown remarkably (see Figure 3.3). In our data, we have only the value of the amount spent by each entity in each media vehicle, so we cannot distinguish ad prices and quantities (number, size or length of placed ads). As TV ads are much more expensive than radio and other ads, the value spent on TV is naturally much higher, although we cannot say anything about how many ads were placed in each media. As a consequence, mean contract values of TV are much higher than the others (see Figures A5 and A6). And, as we can see in Figure A4, there is considerable variation in contract values. The mean contract value is approximately 10 times the median and this is probably due to prices too.

The main limitation of the data is that they only provide us with the total amount spent by the government, not specifying how much was paid to the advertising agency and how much was given to the media vehicle. The value, therefore, can be interpreted as the agencies' total revenue. As seen in Figure A7, the top 10 agencies in terms of revenue have been gathering most part of the ad money, concentrating more than $80 \%$ of the total amount spent by the federal government in 2015 .

When regressing ad spending on past vote for the incumbent party, we use municipality level data, and to estimate the causal impact of ads on votes we use data on the level of polling stations. We describe how we assemble both data sets in what follows next.

\section{2}

\section{Municipality Level Data}

Each media vehicle's tax code number (CNPJ) is also available in the data, which allows us to retrieve the media vehicle's city based on where it was registered. ${ }^{4}$ In terms of territorial distribution, the federal government mainly spends on media companies registered in the capitals. Almost half of the money is poured into São Paulo, the biggest city in Brazil (see Table 3.2). This is probably due to the TV sector too. The main broadcasters in the country are located in São Paulo and, as mentioned before, TV ads are probably the most expensive ones.

Through the available period, the federal government spent advertising money on media vehicles located at 1,979 cities in Brazil, around one third of all municipalities in the country. As seen in Table 3.1, the media vehicles

${ }^{4}$ We are highly grateful to Dimitri Szerman for the help in this task. 
chosen to receive ads money are registered in municipalities that are bigger in terms of population, more urban, richer, more unequal in terms of income and have a more educated population in the baseline year of 2000. This is probably expected since most companies are located in more populated areas and that the eyeballs aimed by advertisers are usually concentrated in the most important cities of the country. Still, even excluding TV spending, the aggregate spending per capita over the 3 relevant presidential cycles here are concentrated in the capitals of Brazil (see Figure 3.4).

The data on presidential elections are made available by the Tribunal Superior Eleitoral (TSE). Presidential elections in Brazil are held every four years, in two-round, first-past-the-post system and winners can be reelected only once. As our advertisement data span the 2000-2015 period, it covers only 3 full mandates, all won by PT, the Brazilian workers' party, in the second round. We therefore use outcomes of the 2006, 2010 and 2014 presidential races on the municipality level. In particular, we construct PT's vote share in every municipality in those 3 presidential elections. To capture a measure of PT's local power, we also use TSE data on municipal elections, which are also held every four years, in the second year of presidential mandates. As we look at PT's vote share, we also identify municipalities ran by mayors affiliated to $\mathrm{PT}$ in the year of presidential elections.

We also gather data on municipality characteristics using the 2000 Census and population estimates by the Brazilian Institute of Geography and Statistics (Instituto Brasileiro de Geografia e Estatística, IBGE). From the Census, we only use measures of income per capita in our regressions, but population education, income inequality, urbanization, among others, are also available.

In Table 3.3 we report the summary statistics of our municipality-level data. The mean ad spending (excluding TV) per municipality in each of the 3 election cycles analyzed is BRL 1.5 million. It is worth noting that there is considerable variation between municipalities across time. In particular, most of the total budget is spent in media vehicles registered in the main cities in Brazil, as mentioned before. Also as mentioned before, almost all the money spent goes through public companies (around 2/3, BRL 1.01). The rest is almost entirely spent by ministries (BRL 0.45) and a very small fraction is spent by other entities (foundations etc., BRL 0.03). The mean spending on TV ads per municipality (BRL 2.63) is more than two times the total spending on all other media taken together. Other than TV, the printed media is the one that gets more money in each cycle per municipality (BRL 0.71), followed by radio (BRL 0.36), other media (out-of-home, outdoors etc., BRL 0.27) and the internet (BRL 0.16). Again, this may also be due to prices. At the political 
side, the PT candidates got, on average over the 2002, 2006 and 2010 elections, $55 \%$ of the votes in the first round and $63 \%$ in the second round. In each of the 3 elections, PT mayors ran around 10 percent of the cities in Brazil.

\section{3}

\section{Polling Station Level Data}

Voting data in polling station level is also provided by TSE. In the 2014 elections, there were approximately 90,000 polling station addresses in Brazil. In order to get their coordinates, we georreferenced them using Nokia's HERE service. ${ }^{5}$ We were able to confidently geocode only approximately 57,000 of those addresses. Non-geocoded addresses are typically associated with rural or isolated areas, so the address is too vague to be processed. In those cases, the software cannot either georreference the address or reports the municipality centroid. Each polling station has one or more voting sections. Data on electoral outcomes and electorate characteristics are available at the section, but not at the polling station level. Thus, we aggregate voting and demographics of all voting sections within the same polling station.

\subsection{1 \\ Radio Coverage}

Radio data is provided by the Agência Nacional de Telecomunicações (ANATEL), the Brazilian telecommunications regulatory agency. It allows us to gather information on all current operating FM and AM radio stations. For each radio station, we get administrative data, such as the station's name and tax code number (CNPJ), and technical data, which is basically the antenna's specifications and coordinates. One important variable is the estimated signal range in kilometers for each radio station. ANATEL itself estimates what is called the protected contour, which we use as estimated radio signal range. ${ }^{6}$ This variable is only available for FM stations due to the nature of the FM signal. ${ }^{7}$ In our analysis, thus, we focus on FM radio stations. The main limitation here is that ANATEL only provides cross-sectional data

${ }^{5}$ To do that, we used Stata's geocode package. Google Maps could also be used, but the current API available to do that uses Google Places, which is suitable for addresses that correspond to identified places on Google's database.

${ }^{6}$ Protected contour is the area in which signal reception is protected from interference caused by other stations on the same channel or adjacent channels or frequencies. ANATEL classifies FM stations into 10 classes according to its technical features. Each class has an associated maximum and minimum protected contour. Here we conservatively use the minimum value. The precise estimation of the radio signal range using detailed antenna specifications and terrain features (such as done by (25)) would be a natural improvement.

${ }^{7}$ The main predictors of FM signal coverage are antenna's specs and terrain. On the other hand, AM signal coverage depends heavily on ground conductivity. 
on the current operating radio stations. Data do not go back in time, so we cannot identify, for instance, stations that no longer operate, even though there may be some stations that were active during the period for which we have the ad data.

We collected the data from ANATEL's website on October 2016. As in our exercise we use 2014 election data, an important hypothesis here is that the operating stations in this date did not change much compared to those operating in $2014 .{ }^{8}$ In 2016, there were approximately 2,500 FM and 1,800 AM operating radio stations in Brazil. There were also 4,500 1km-range FM radio stations, called community radio stations (rádios comunitárias), which we will not use here. As it will become clear in Section 5, those stations have a very limited range to fit our empirical strategy.

Figure 3.5 plots all FM and AM stations in the Brazilian territory. It is important to notice that there is a great overlap of FM and AM antennas over the Brazilian territory. In particular, they are concentrated in the main metropolitan areas of Brazil, specially in the South, Southeast and in the Northeast of the country. A natural explanation for this is that most of the radio potential audience is located in the most populated areas of the country. It is important to notice that AM radio stations also get ad money from the federal government through the relevant period we analyze. However, as predicting coverage of AM radio station is a more complicated task, we focus on FM stations. As it will be clearer in Section 5, we try to overcome this issue.

The results in terms of signal coverage of polling stations are presented in Figure 3.6, in which we plot the polling stations we georeferenced over the territory. The gray circles are those that get no FM radio signal. The red ones are those that get FM signal from stations that did not receive federal government ad money over the 2011-2014 period (non-sponsored). The green ones are the sponsored ones and the size of each green dot is proportional to the number of sponsored signals the polling stations get. Due to the simultaneous concentration of polling stations and radio, the polling stations located at the most populated areas of Brazil end up receiving signals from multiple stations. As seen in the first part of this article, those are also the places where the federal government pours more money into, so there are few polling station that get only non-sponsored signal.

${ }^{8}$ Although this is probably not true, opening a radio station is costly, as it involves getting a public license. 


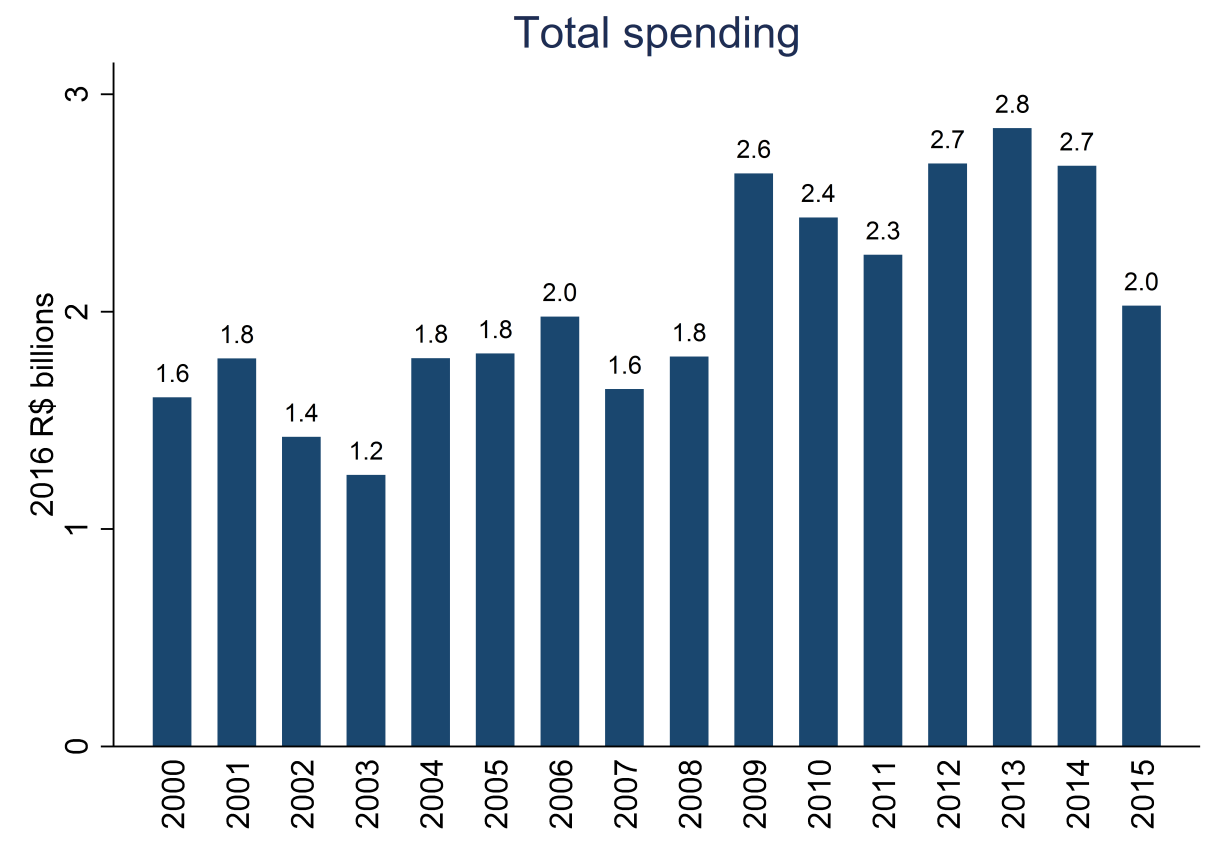

Figure 3.1: Total federal government spending on ads: 2000-2015

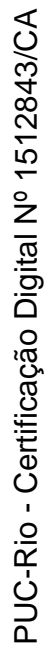

Notes: This figure plots the total amount spent on ads by the Brazilian federal government through all its entities, from 2000 to 2015. Values are in 2016 Brazilian Reais (R\$).

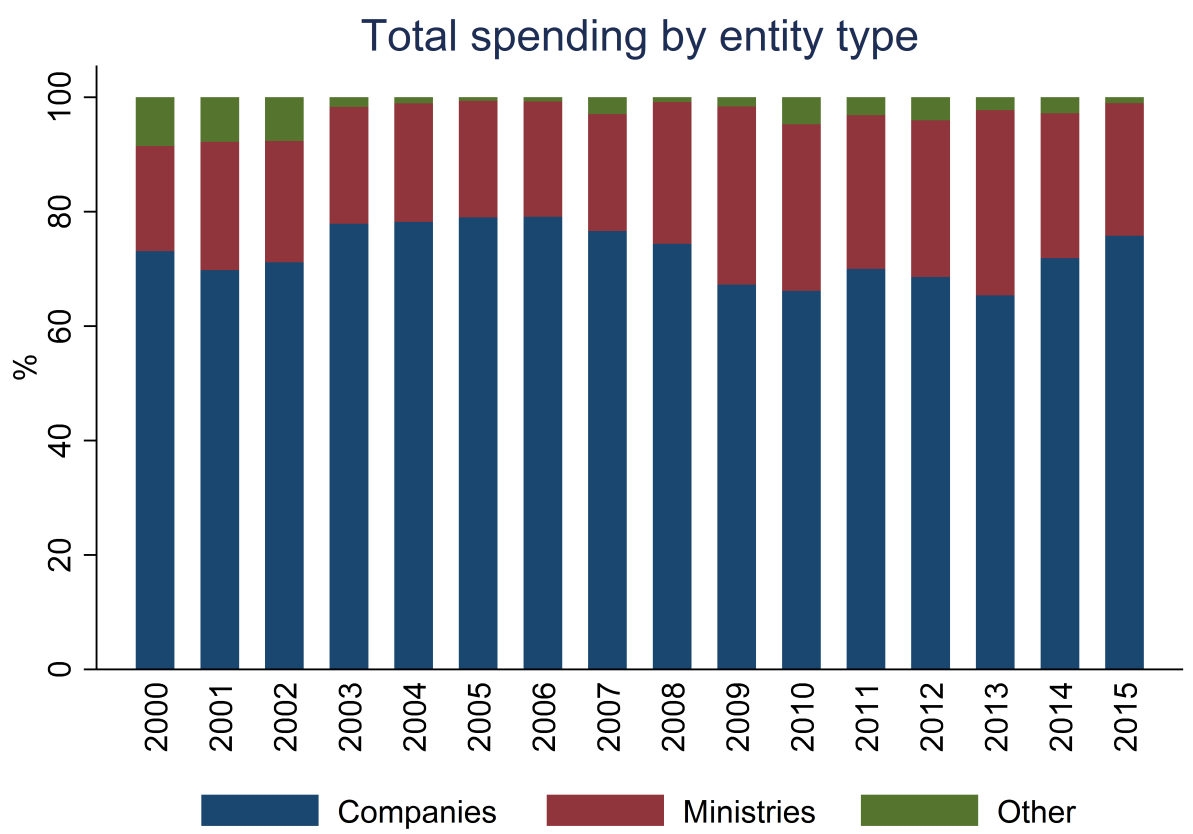

Figure 3.2: Federal government spending on ads, by entity type: 2000-2015

Notes: This figure plots the share of the total federal government advertisement budget spent by public companies, ministries and other entities. 


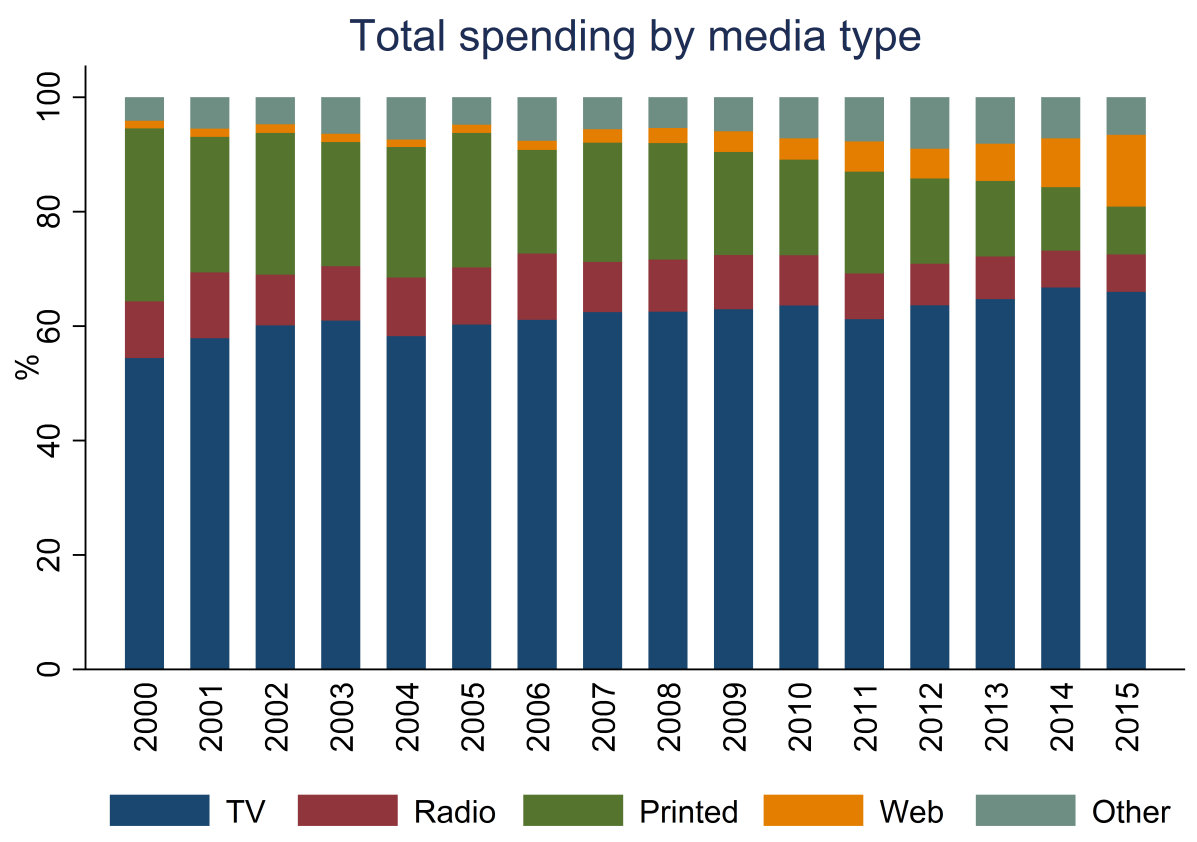

Figure 3.3: Federal government spending on ads, by media type: 2000-2015

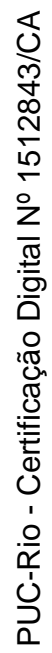

Notes: This figure plots the share of total federal government advertisement budget spent on different types of media, namely TV, radio, printed media, internet and other media. 


\begin{tabular}{rccc}
\hline & No ads & Ads & diff. p-value \\
\cline { 2 - 4 } Total population (thousands) & 9.03 & 69.44 & 0.00 \\
Share of urban population & 0.51 & $(6.91)$ & \\
& $(0.00)$ & $(0.00)$ & 0.00 \\
$\log$ (Income per capita) & 5.50 & 5.95 & 0.00 \\
& $(0.01)$ & $(0.01)$ & \\
Expected years of education & 8.07 & 8.82 & 0.00 \\
& $(0.03)$ & $(0.03)$ & \\
Gini coefficient & 0.54 & 0.56 & 0.00 \\
& $(0.00)$ & $(0.00)$ & \\
$\mathrm{N}$ & 3586 & 1979 & \\
\hline
\end{tabular}

Table 3.1: Characteristics of the municipalities where media vehicles chosen to receive advertising money are located at

Notes: This table reports the comparison of means of the characteristics between municipalities where media vehicles chosen to receive advertising money are located and all other municipalities in the 2000-2015 period. To do that, we use the 2000 Census to gather variables that report the total population (in thousands of people), share of urban population, log of income per capita, expected years of education of the population and the Gini coefficient. The last column reports the p-value of the t-test when comparing relevant means.

\begin{tabular}{ccc}
\hline Rank & City & \% total spending \\
\hline 1 & São Paulo & 49.2 \\
2 & Rio de Janeiro & 13.8 \\
3 & Brasília & 5.2 \\
4 & Belo Horizonte & 2.8 \\
5 & Porto Alegre & 2.7 \\
6 & Salvador & 2.1 \\
7 & Curitiba & 1.8 \\
8 & Recife & 1.6 \\
9 & Fortaleza & 1.5 \\
10 & Belém & 0.7 \\
\hline
\end{tabular}

Table 3.2: City ranking

Notes: This table reports the ranking of the Brazilian municipalities where media vehicles chosen to receive advertising money located at in terms of the share of the budget (excluding TV ads) poured into each city in the 2000-2015 period. 


\begin{tabular}{|c|c|c|c|c|}
\hline \multirow{2}{*}{\multicolumn{5}{|c|}{ Total cycle spending: 2003-06, 2007-10 and 2011-14 cycles (2016 BRL millions) }} \\
\hline & & & & \\
\hline Total cycle spending (exc TV) & 1.50 & 34.88 & 0.00 & 1745.29 \\
\hline State company cycle spending (exc TV) & 1.01 & 25.26 & 0.00 & 1167.57 \\
\hline Ministry cycle spending (exc TV) & 0.45 & 9.21 & 0.00 & 521.67 \\
\hline Other entity cycle spending (exc TV) & 0.03 & 0.97 & 0.00 & 56.05 \\
\hline TV cycle spending & 2.63 & 69.85 & 0.00 & 2925.65 \\
\hline Printed media cycle spending & 0.71 & 19.49 & 0.00 & 864.14 \\
\hline Radio cycle spending & 0.36 & 5.86 & 0.00 & 252.34 \\
\hline Web cycle spending & 0.16 & 6.32 & 0.00 & 445.15 \\
\hline Other media cycle spending & 0.27 & 4.94 & 0.00 & 226.52 \\
\hline
\end{tabular}

Presidential elections: 2002, 2006, 2010 and 2014 elections

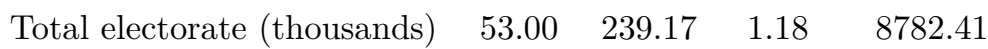

Round 1

\begin{tabular}{|c|c|c|c|c|}
\hline PT vote share & 47.13 & 15.93 & 7.09 & 90.67 \\
\hline \multicolumn{5}{|l|}{ Round 2} \\
\hline PT vote share & 56.00 & 15.77 & 14.71 & 94.69 \\
\hline \multicolumn{5}{|c|}{ Local power variables (on presidential election years) } \\
\hline$=1$ if $\mathrm{PT}$ mayor & 0.10 & 0.30 & 0.00 & 1.00 \\
\hline \multicolumn{5}{|c|}{ Municipality characteristics at cycle start: 2002, 2006, 2010 and 2014} \\
\hline Population at cycle start (thousands) & 77.87 & 333.50 & 1.41 & 11895.89 \\
\hline GDP per capita at cycle start (2016 BRL thousands) & 0.02 & 0.02 & 0.00 & 0.48 \\
\hline
\end{tabular}

Table 3.3: Summary statistics

This table reports the summary statistics of the relevant variables of the municipality-level exercise. In particular, it contains the mean, standard deviation, minimum and maximum of (i) government spending on ads: total, split by entity and media type and spending of selected companies (Petrobras, Correios, Banco do Brasil and Caixa), in the 4-year cycles of 2003-2006, 2007-2010 and 2011-2014 in 2016 Brazilian reais; (ii) total electorate, in thousands of people; (ii) Rounds 1 and 2. 


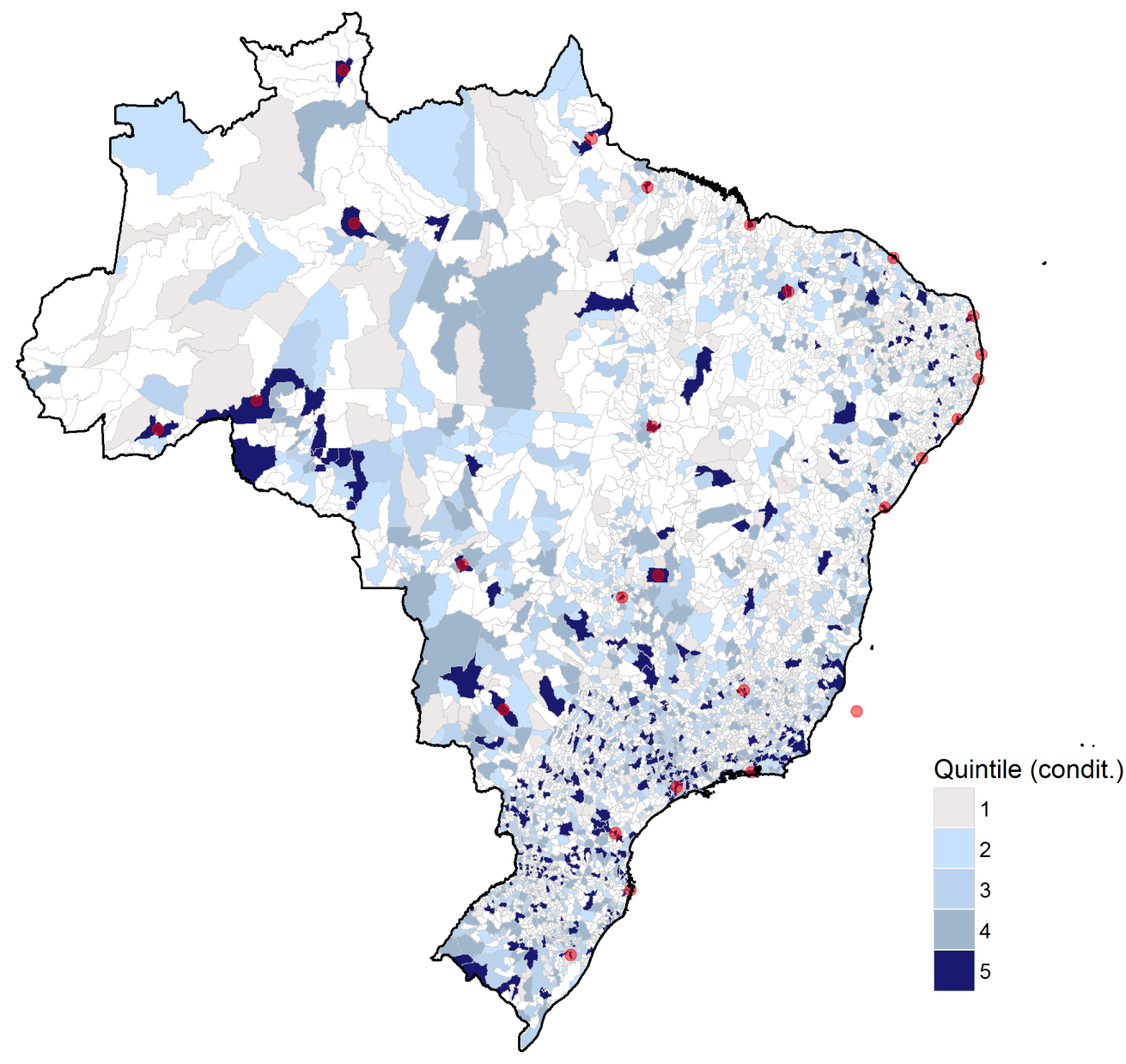

Figure 3.4: Spending per capita (2003-2014, excluding TV), capital centroids in red

Notes: This figure plots the total amount per capita (in 2016 Brazilian Reais, $\mathrm{R} \$$, excluding TV) spent by federal government entities in each municipality over the Brazilian territory in 2003-2014. White areas correspond to zero spending, while the others are filled by quintiles. Red circles correspond to capital centroids. 


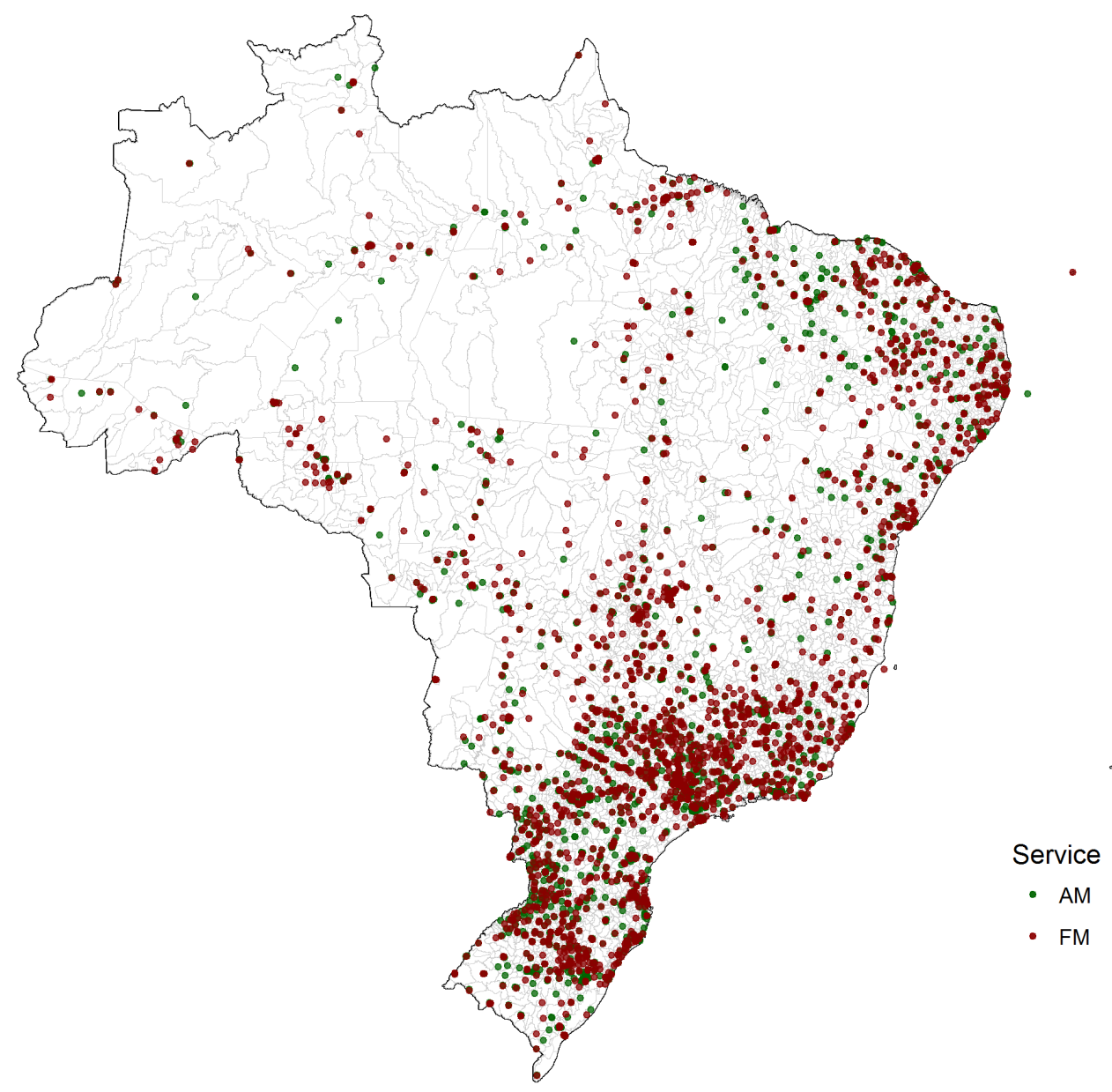

Figure 3.5: FM and AM radio stations

Notes: This figure plots FM and AM radio stations operating in the year of 2016. Red dots correspond to FM antennas and green to AM antennas. Data are provided by ANATEL and were retrieved on October 2016. 


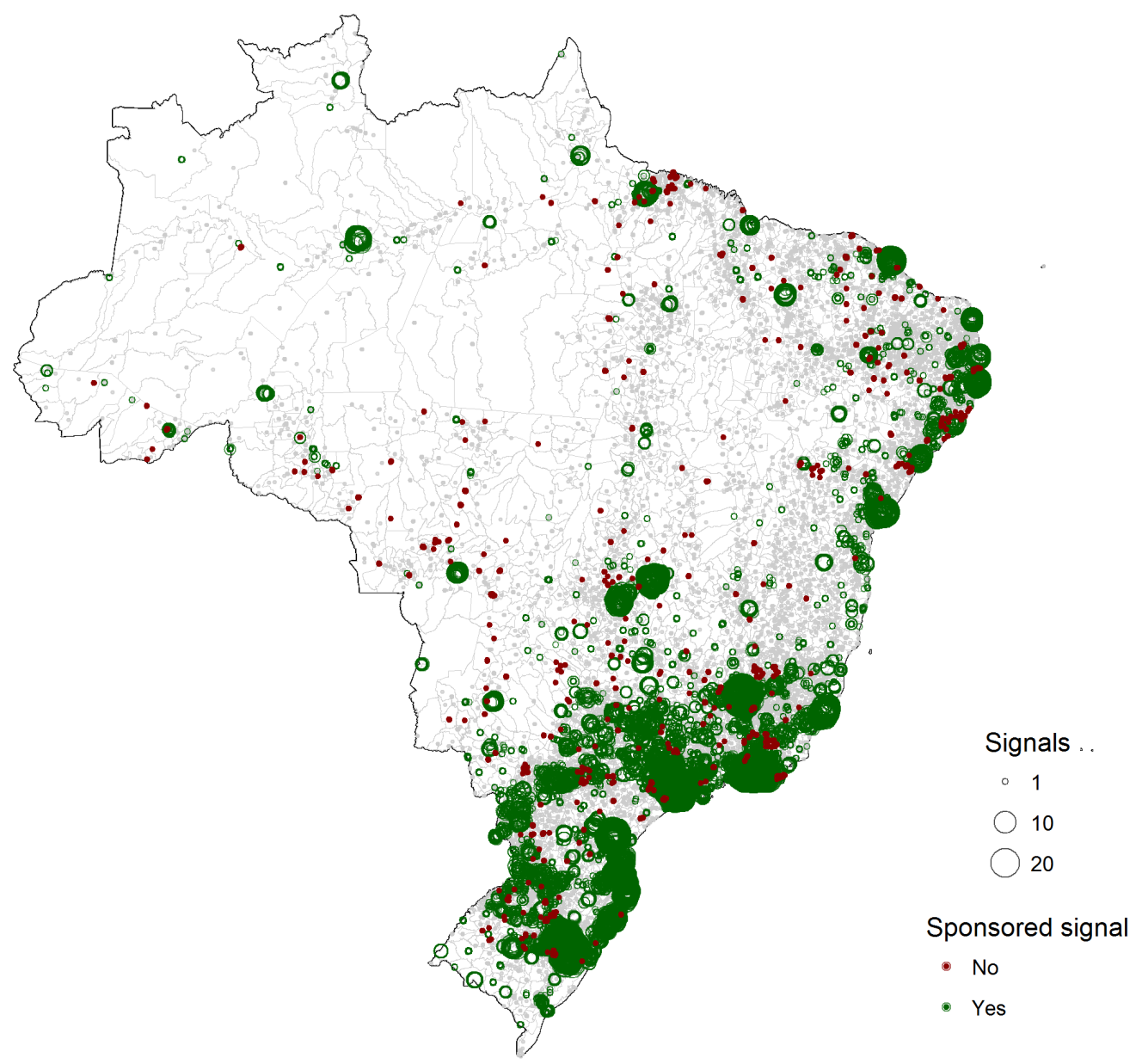

Figure 3.6: 2014 Polling stations and radio coverage

Notes: This figure plots all geocoded polling stations in the 2014 presidential election and their treatment status. Gray dots are polling stations that get no FM radio signal and the red ones are those that get non-sponsored signal. Green dots are polling stations that get at least one sponsored signal, and the size of the dots correspond to how many sponsored signal those polling stations get. 


\section{4}

\section{Government Advertisement and Past Voting}

\section{1}

\section{Empirical Strategy}

In order to estimate how the allocation of the advertisement budget is related to (past) electoral outcomes, we regress (log of) ad spending per capita in each presidential cycle on (past) share of votes for PT in municipality level and municipality level controls. We also include municipality and time fixed effects. When doing so, we only capture spending variation over time within each municipality. The regressions we run, thus, take the following general form:

$$
\begin{aligned}
\log (\text { avg. spending per capita })_{i t} & =\beta_{0}+\beta_{1} \text { PT }_{\text {share }}+\beta_{2} \text { PTmayor }_{i t} \\
& +X_{i t}+\gamma_{i}+\eta_{t}+\epsilon_{i t}
\end{aligned}
$$

where avg. spending per capita ${ }_{i t}$ is the average ad spending per capita in municipality $i$ over the subsequent 4-year cycle after election year $t, P T$ share $_{i t}$ is the share of votes for PT on presidential elections in year $t$ in municipality $i$, PTmayor is a dummy variable that takes the value of 1 when, in municipality $i$ in a given year $t$, the mayor is affiliated to $\mathrm{PT}$, and $X_{i t}$ are time and municipality-varying controls, namely log of GDP per capita and log of population. We run regressions using only 3 election years (2002, 2006 and 2010) and aggregate spending in the subsequent 4-year cycle that corresponds to a presidential mandate. When constructing measures of spending per capita, we use the population in election years. As we use time and municipality fixed effects, we only keep in our database those cities that received money at some point of time and explore variation within cities over time.

We exclude TV ads when aggregating spending per municipality on most of our specifications due to the nature of the TV service. The range of the TV signal is much broader than the radio one; thus, the audience is much more limited than, say, the one newspapers and magazines. Although it is probably valid in some sense for all other media, aggregating TV spending per municipality probably does not capture money being poured in a local fashion. 
Our main specification includes spending on all types of media outlets (except for TV in most cases) and spending by all public bodies. Additional specifications break the spending variable on the left-hand size of Equation $4-1$, according to the type of media the money was spent on (printed media, radio, web, TV and others) and to the type of entity placed the ads, namely ministries, public companies and other entities.

Before presenting the results, it is worth discussing what to expect from the described exercises. First, if the goal of the federal government when choosing where to spend the ad money is to build local support, we should see more money being spent on media outlets located at municipalities with lower share of votes for PT in the past. In this case, $\beta_{1}$ in Equation 4-1 should be negative. If public companies try to maximize profit, we probably should not see them spending money based on election outcomes, once we control for municipality characteristics that may determine voting results. In this case, when only using public company spending, $\beta_{1}$ in Equation 4-1 should not be statistically different from zero. Finally, if the federal government wants to gather votes locally by pouring ad money into media outlets, low range media, such as radio, not TV, is probably more suitable to do that. Thus, when running regressions like Equation 4-1 for each type of media separately, $\beta_{1}$ should be indistinguishable from zero when using spending on TV, for instance.

\section{2 \\ Results}

The results of the estimation of Equation 4-1 using our main specification are presented in Table 4.1. Columns 1-3 report the results using first round electoral outcomes. In column 1 , the $\beta_{1}$ point estimate is -0.052 . One standard deviation decrease in PT vote share in a municipality is associated with approximately $0.8 \%$ increase in ad spending per capita. Alternatively, moving from the $75^{\text {th }}$ to the $25^{\text {th }}$ percentile in the vote share distribution (which corresponds to a 30 p.p. drop in the first round) is associated with a $1.7 \%$ increase in spending per capita. In column 2, we include a dummy that assumes value of 1 for municipalities that had a PT mayor in the election year to capture PT local power (PTmayor). Still, the coefficient of interest remains unchanged and the one associated with the local power dummy cannot be distinguished from zero. In column 3, we include the local power dummy and drop the cities in the top $1 \%$ of the population distribution, aiming at excluding the main cities of Brazil. As seen before, those are the ones that get most of the ad budget. When dropping them from our sample in this specification, we test 
whether the relation observed in previous specifications is driven by big city dynamics. The coefficients, however, remain virtually unchanged.

In columns 4-6, we run analogous regressions shown in columns 13 using only electoral outcomes of second round races. Our coefficient of interest reports a stronger relation between spending on advertising and past votes (-0.063). Now, one standard deviation decrease in PT vote share in a municipality is associated with approximately $1 \%$ increase in ad spending per capita in the second round. Alternatively, moving from the $75^{\text {th }}$ to the $25^{\text {th }}$ percentile in the vote share distribution (which corresponds to a 20 p.p. drop in the second round) is associated with a $1.8 \%$ increase in spending per capita in each round. Again, when including measures of local power and dropping the most populated cities of our sample, the point estimates remain virtually unchanged.

In Tables 4.2 and 4.3, we run separate regressions for spending by public companies, ministries and other public entities. The columns are analogous to those in Table 4.1. The relation between votes and ad spending captured by $\beta_{1}$ is weaker in regressions using just state company contracts (columns 1-6, Table 4.2). The coefficients of interest are around -0.02 or half the estimates using the main specification. Coefficients when using only money spent by ministries (columns 5-12, Table 4.2), on the other hand, are twice as big as the ones in state company regressions and closer to the coefficients presented in Table 4.1. One possible interpretation is that ministries are more subject to political interference and, thus, more likely to pour money into media outlets having in mind electoral outcomes. Public companies, on the other hand, may be more constrained when choosing where to place ads, taking decisions closer to what is expected to be a profit-maximizing behavior.

In Tables 4.4, 4.5 and 4.6, we break the spending according to media type (TV, radio, printed media, internet and others, such as out-of-home media etc.). In Table 4.4, columns 1-6 present the results using spending on printed media and columns $7-12$ report the estimates using radio. Table 4.5 reports the web and TV specifications and Table 4.6 reports the estimates using other media. Column specifications are analogous to those presented in Table 4.1. As we expected, spending on printed media and specially radio is more strongly related to past voting outcomes than TV and other media spending. Printed media coefficients are -0.011 in the first round and around -0.016 in the second round. Radio estimates are -0.045 and around -0.055 in each round, respectively. Somewhat surprisingly, money spent on the internet is also strongly associated with past votes for PT. This is not expected since the internet can be accessed from anywhere, so the audience that accesses the 
media outlets that get advertising money is more diffuse. Therefore, the web probably lacks the potential to be used as a local media to gather votes.

\section{3}

\section{Spending on Election Years}

Next, we asses the association between votes and ad spending in the election years. It may be the case, as argued by the literature on opportunistic political cycles (see e.g. (31)), that federal government increases spending prior to the election. To test this hypothesis using our (yearly) data, we use ad spending on election years. Two important caveats must be noticed. First, elections in Brazil are held in October and our data spans the total year spending. The value spent by year, thus, is overestimated in this exercise. Second, the federal government must not spend freely the ad budget on election years. ${ }^{1}$

As we have data on government ad spending on the year of 2014, er are able to include this year in our exercises. We run the same regressions as those presented above, but now we use year spending on the right-hand side. The results are presented in Tables B1-B5. The conclusions are very similar to those obtained when using 4-year cycle spending, but the association seems to be weaker (the absolute values of the relevant coefficients are smaller).

In sum, we show that there is a significant negative relation between federal government spending on media vehicles and vote share for the incumbent party in the municipalities where those outlets are located. This relation is stronger when taking only the money spent by ministries and in printed media and radio. This is compatible with the incumbent party financing local, low-range media through ministries to gather votes locally. The estimates, however, are economically small. This is compatible with a situation in which the federal government does not aggressively allocates the ad budget aiming at gathering votes. This could happen, for instance, due other strategies being played when allocating ad money that are related to market characteristics. The small association between past votes and ad spending is, thus, compatible with the results found in the next session, in which we show that the ad money does not seem to increase vote share in a causal way.

\footnotetext{
${ }^{1}$ Brazil's Fiscal Responsability Law (101/2000) limits ad spending not the be greater than i) previous year spending or ii) average spending of previous 3 years. Electoral Law (9504/1997) only allow institutional campaigns up to 3 months prior to the first round of the race on election years.
} 


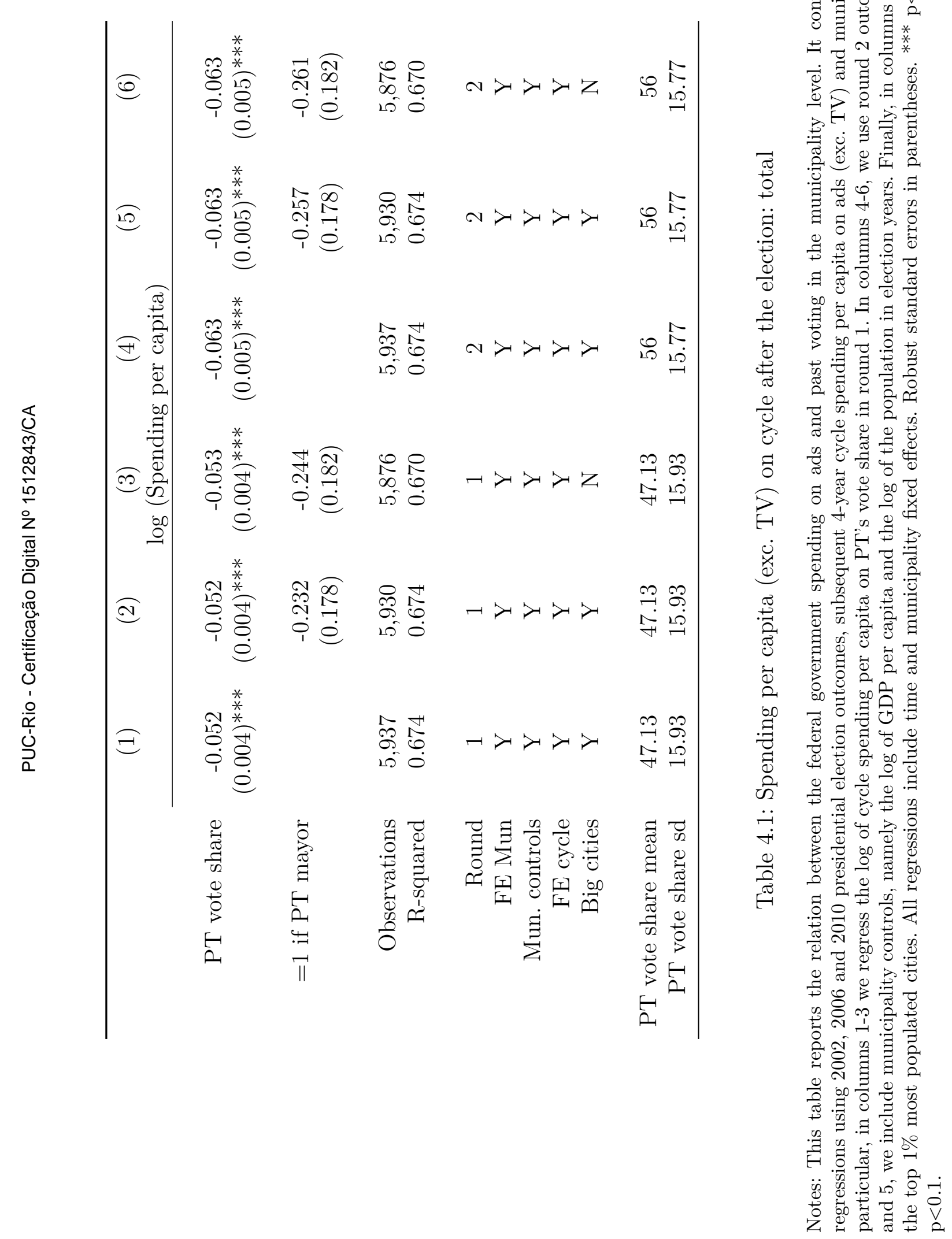




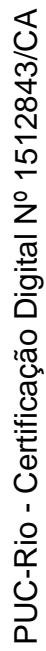

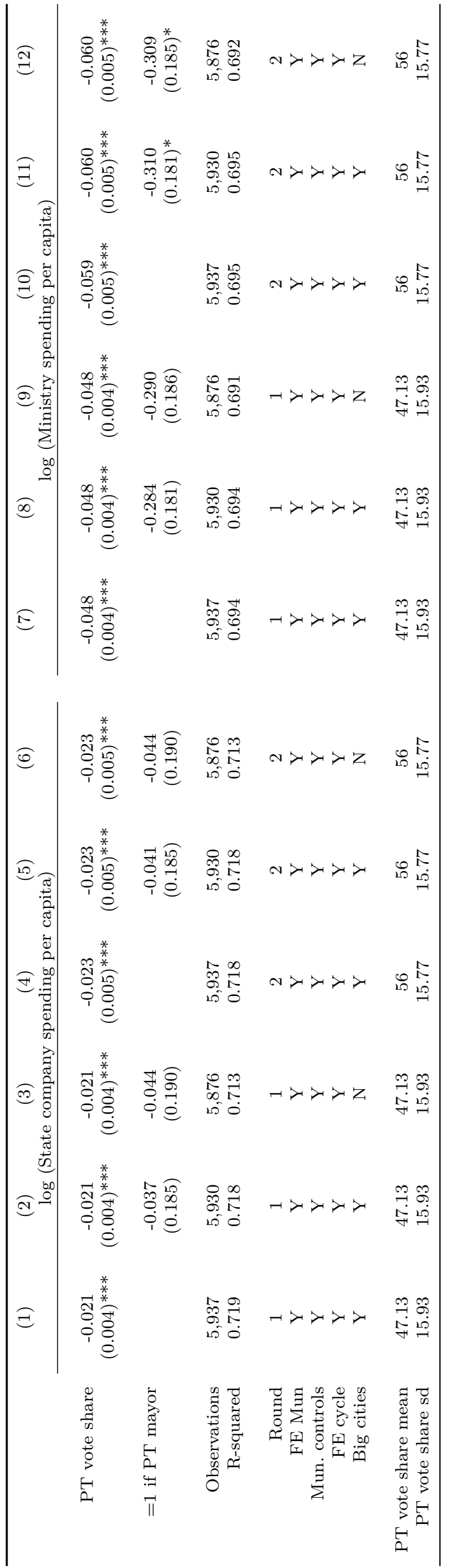

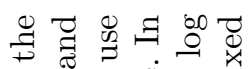

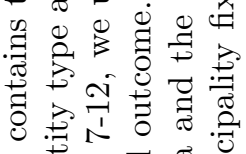

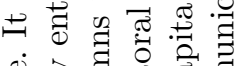

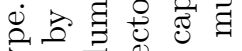

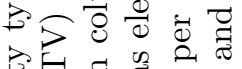

:

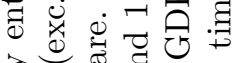

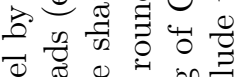

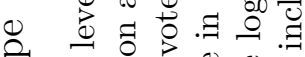

B.

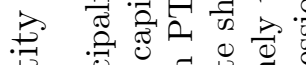

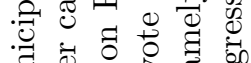

青设

s.

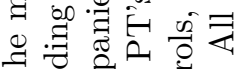

ఫ

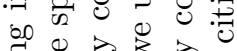

.$尹$

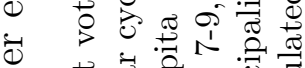

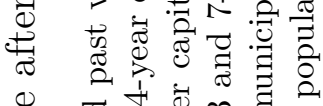

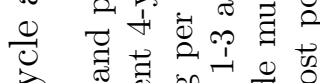

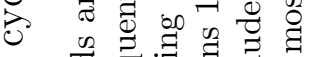

б

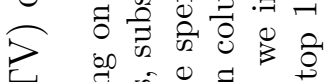

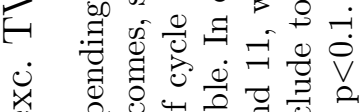

选 क

\%

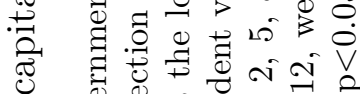

पे

क

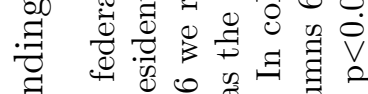

娄

की

نे

计

党

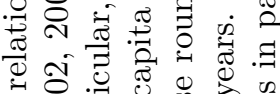

ชิ

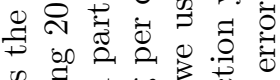

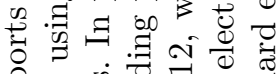

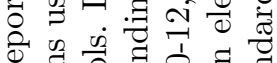

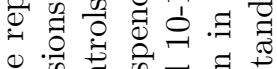

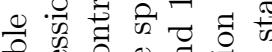

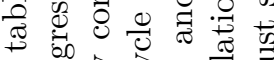

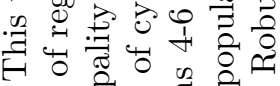

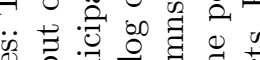

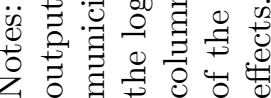




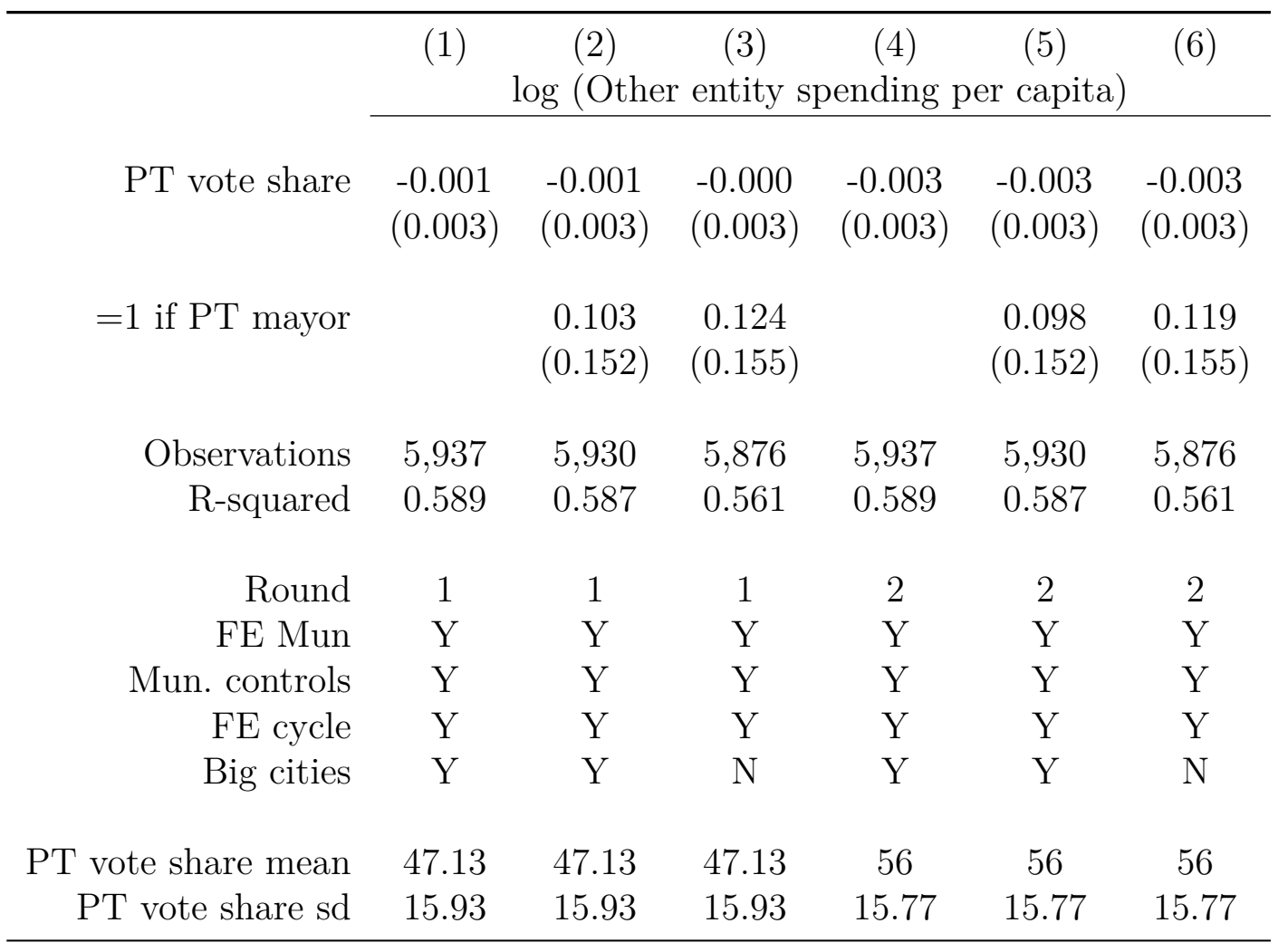

Table 4.3: Spending per capita (exc. TV) on cycle after election: by entity type

Notes: This table reports the relation between the federal government spending on ads and past voting in the municipality level by entity type. It contains the output of regressions using 2002, 2006 and 2010 presidential election outcomes, subsequent 4-year cycle spending per capita on ads (exc. TV) by entity type and municipality controls. In particular, in columns 16 we regress log of cycle spending per capita by other entities (foundations etc.) on PT's vote share. In columns 1-3, we use PT's vote share in round 1 as electoral outcome. In columns $4-6$, we use round 2 outcomes. In columns 2 and 5 , we include municipality controls, namely the $\log$ of GDP per capita and the log of the population in election years. Finally, in column 6 we exclude top $1 \%$ most populated cities. All regressions include time and municipality fixed effects. Robust standard errors in parentheses. ${ }^{* *} \mathrm{p}<0.01,{ }^{* *} \mathrm{p}<0.05,{ }^{*} \mathrm{p}<0.1$. 


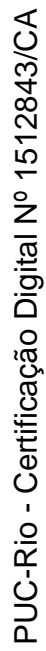

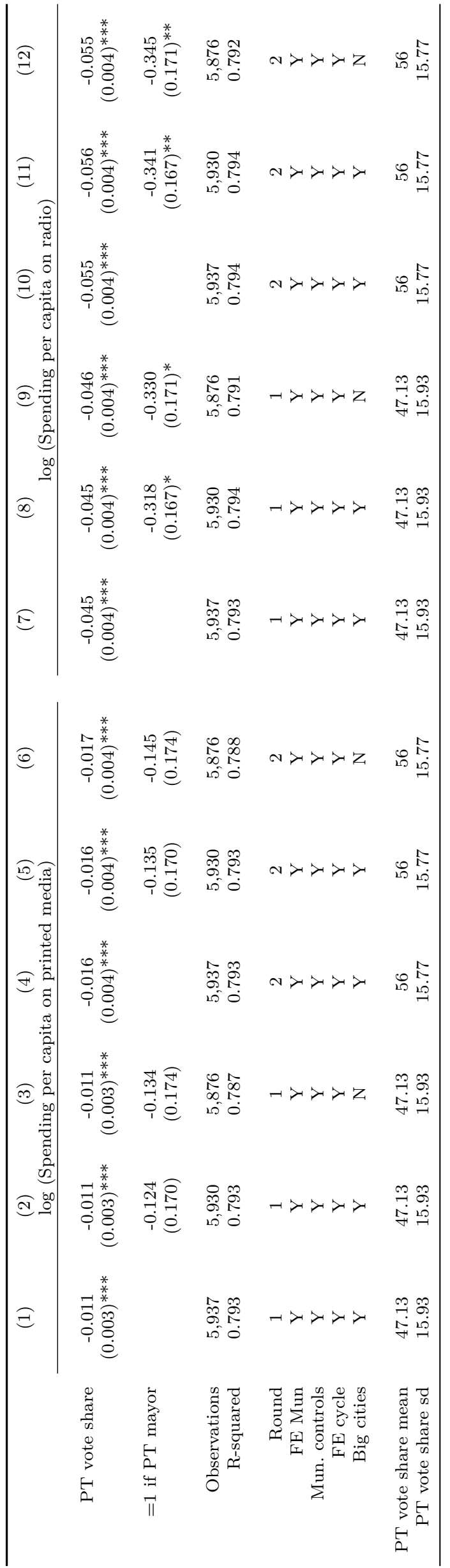

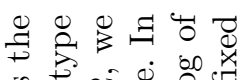

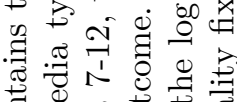

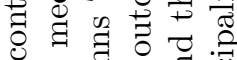

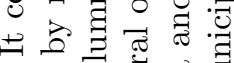

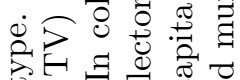

उस

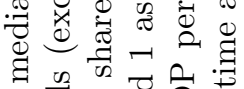

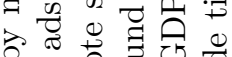
$\overrightarrow{0}$ o 8 o

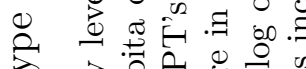

B. 30.

๘

窇

a $\quad$ 范

3.

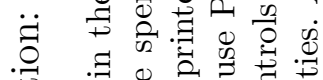

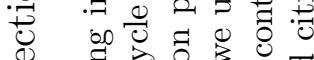

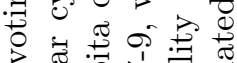

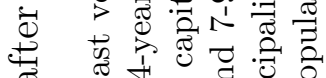

更

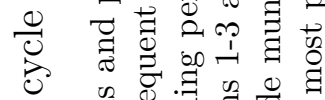

न

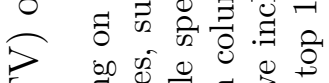

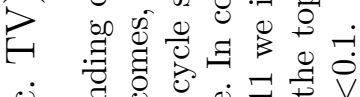

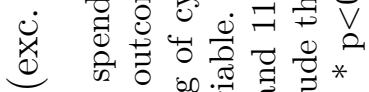

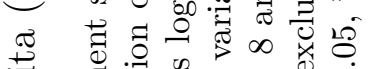

: $\quad$ :

ช

¿)

क

b

के

थ

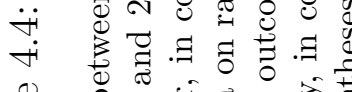

唄

丞

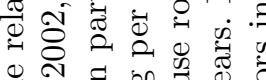

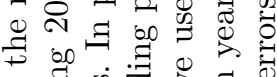

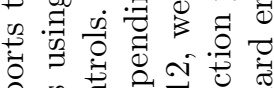

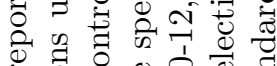

$\rightarrow .000000$

0.

50

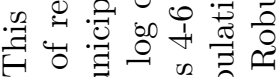

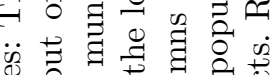

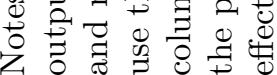




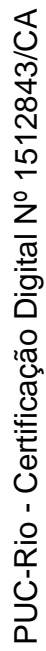

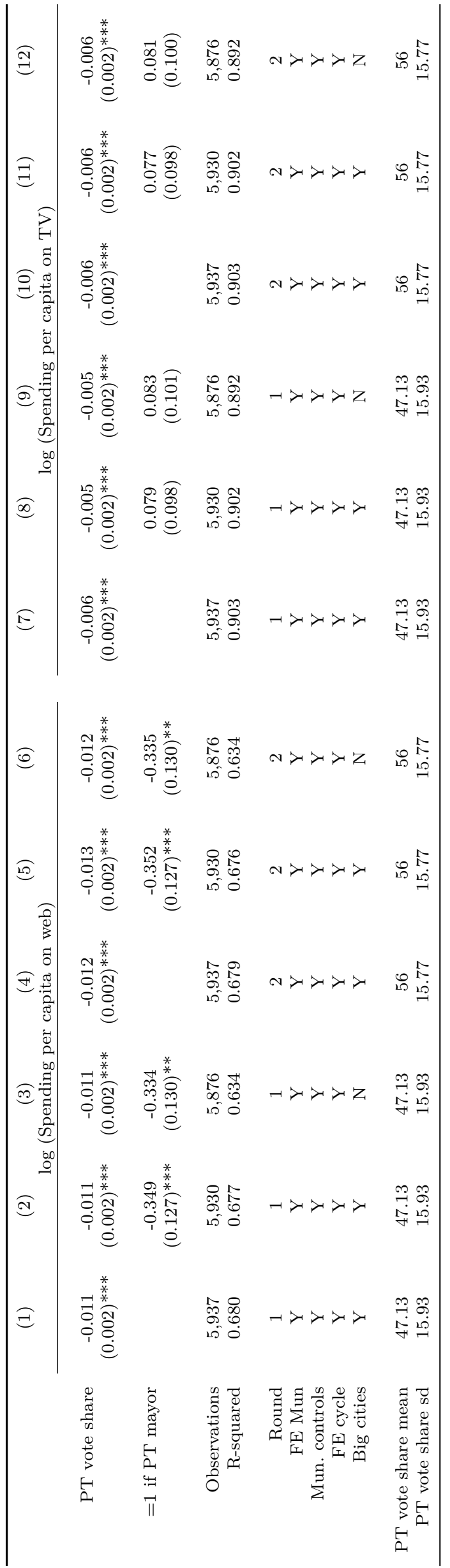

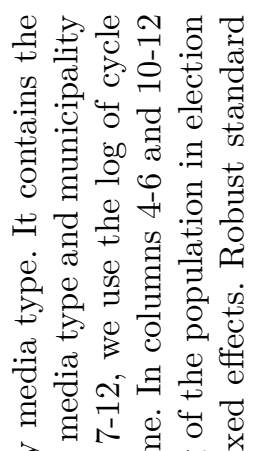

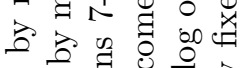
인.

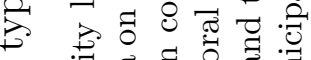

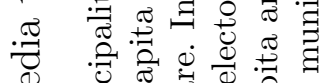

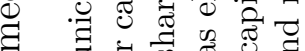
b) छ -

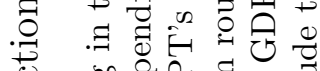
递 ه $\dot{0}>0.07 \%$

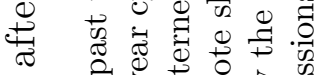
品 ठ व

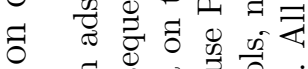

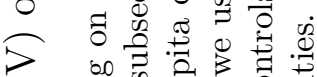

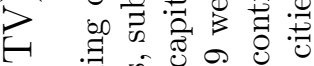

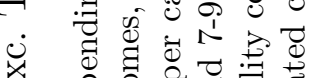

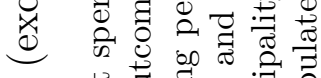

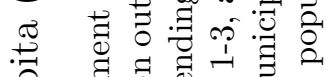

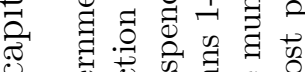
ช का

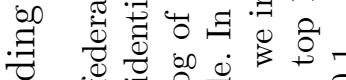

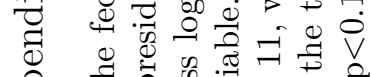
की मूँ

ن.

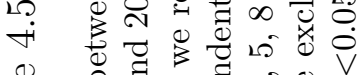

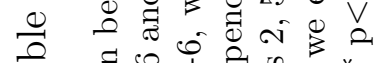
준

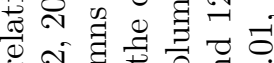
论

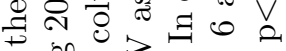

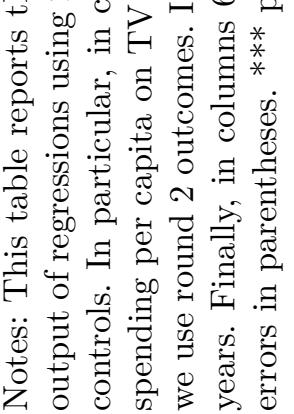




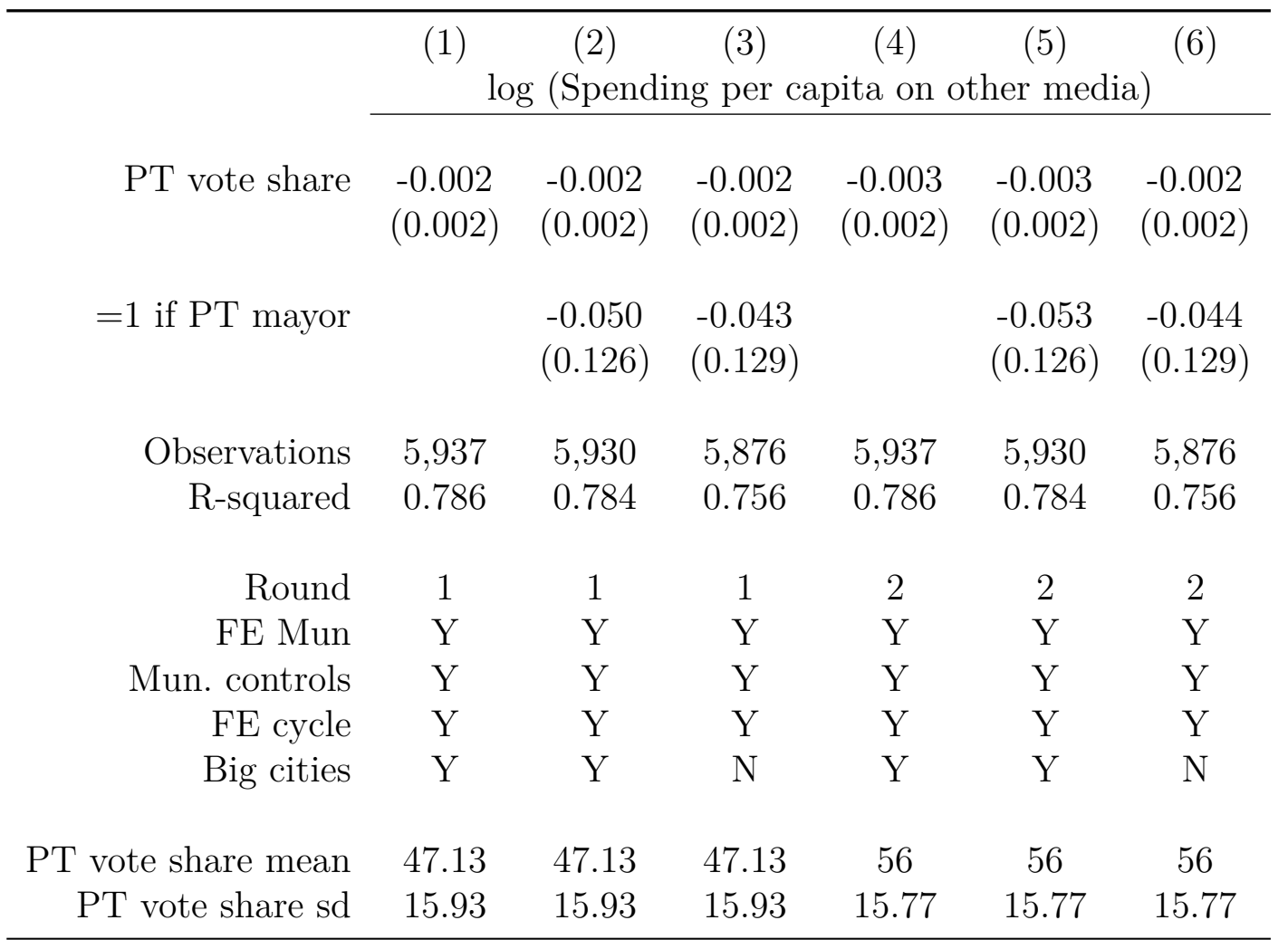

Table 4.6: Spending per capita (exc. TV) on cycle after election: by media type

Notes: This table reports the relation between the federal government spending on ads and past voting in the municipality level by media type. It contains the output of regressions using 2002, 2006 and 2010 presidential election outcomes, subsequent 4-year cycle spending per capita on ads by media type and municipality controls. In particular, in columns 1-6, we regress the log of cycle spending per capita on other media (outdoors, out-of-home etc.) on PT's vote share. In columns 1-3 we use PT's vote share in round 1 as electoral outcome. In columns 4-6, we use round 2 outcomes. In columns 2 and 5 , we include municipality controls, namely the $\log$ of GDP per capita and the $\log$ of population in election years. Finally, in column 6 , we exclude the top $1 \%$ most populated cities. All regressions include time and municipality fixed effects. Robust standard errors in parentheses. ${ }^{* * *} \mathrm{p}<0.01,{ }^{* *} \mathrm{p}<0.05,{ }^{*}$ $\mathrm{p}<0.1$. 


\section{Does Advertisement Affect Voters? Evidence from Radio}

In Section 4, we show how spending on advertisement by the federal government is related to past voting patterns in the municipality level. As mentioned before, the relations we describe are not causal, but help drawing a motivating picture of where in the territory the government places ads and how this is related to electoral outcomes. Now we take a step further to answer empirically whether this money may actually help (in a causal way) the government gathering votes locally.

\section{1}

\section{Empirical Strategy}

When assessing the impact of the government advertising on voting, we explore the exogenous variation associated with the radio service. Intuitively, we can imagine that the government may target with advertising money radio stations that reach specific audiences. However, due to the way that radio signal is propagated, some audiences get the signal and some do not. The idea here is to compare audiences close enough to be similar in observable and non-observable characteristics, but one gets the radio signal and the other(s) does(do) not.

Specifically, we identify polling stations that get signal from a FM radio station that received federal ad money at some of point of time in the 20112014 period (we call this sponsored signal). To do tht, for each FM antenna in Brazil we take the furthest sponsored polling station within the covered range and look for close enough polling stations that either only get signals from FM radio stations that did not receive ad money (non-sponsored signal) or that get no signal at all (no signal). The idea behind taking only the furthest polling station that gets sponsored signal for each antenna is to explore the geographic features of our exercise similarly to what is done in Geographic Regression Discontinuity Design (see $(32,33,34,35,36)$ ). However, we take the treated polling stations that are closest to the "border" (coverage radius) and use as controls the ones that are close enough to the treated ones. Thus, our exercise differs from GRRD in a sense that it does not compare treated and control observations based on the distance to the border, but the distance 
between treated and controls that are close to the border. The general equation we estimate takes the following form:

$$
\text { PTshare }_{i}=\beta_{0}+\beta_{1} \cdot \text { spons }_{i}+X_{i}+\gamma_{s}+u_{i}
$$

where PTshare $_{i}$ is the PT vote share in polling station $i$, spons $_{i}$ is the treatment variable, $X_{i}$ is a vector of polling station characteristics and $\gamma_{s}$ is a fixed effect for each treated polling station and its corresponding controls, located at a certain distance. An illustration of our empirical strategy is shown in Figure C1.

We propose different specifications for the treatment variable, spons $s_{i}$. They may capture whether the polling station gets a sponsored signal, how many signals it gets and how much is spent on the FM radio stations it gets signals from. We also explore the fact that a polling station may get radio signals coming from other municipality. When doing this, we may fully explore the exogenous variation allowed by geography.

As the ad campaigns ran by the government do not carry explicit political or partisan content, the different treatment status we assemble probably captures media bias induced by the financing of media outlet. In the context of our empirical strategy design, then, $\beta_{1}$ captures the difference in the share of votes for PT observed in polling stations exposed to information propagated by radio stations financed by the government in comparison to polling stations in the control group. Thus, the mechanism we have in mind is similar to what was highlighted by Di (22) when studying Argentina: money spent by the government may be a relevant source of revenue to media outlets, and the threat to lose it may induce media bias.

As mentioned briefly before, there are two types of polling stations that can be used to construct the control group: (i) the ones that get no FM radio signal; and (ii) those that only get non-sponsored FM radio signal. Our preferred specifications are those that use as control group the polling stations that get no radio signal and are located within 5 kilometers from the treated ones. As mentioned before, the radio stations are geographically concentrated in the Southeast and Northeast, which correspond to most urban areas of Brazil. When using the no-signal control group, we are probably on more solid grounds to explore the exogenous variation of radio signal coverage that comes from geography. The reason that one polling station does not get any radio signal but is close to one that gets is probably mostly driven by geographic factors.

Finally, one additional advantage of using polling stations that get no FM radio signal as a control group is the number of observations. As seen 
in Figure 3.6, there are very few polling stations that get non-sponsored FM radio signal, so the number of observations when we compare treatment and control groups within a short distance is small, and inference may be harder. On the other hand, when choosing the no-signal control group over the nonsponsored one, we focus on polling stations located at not so urban areas of the country and that are potentially very different in terms of both observed and non-observed characteristics from those that are covered by radio. However, polling stations that get at least one sponsored signal and those that get no signal look very similar in a number of observable characteristics when taking a sufficient small distance. Moreover, as almost all polling stations that receive FM signal also are the ones that get sponsored FM signals, we can't clearly distinguished our estimates from the impact of simply getting FM radio signal on votes. However, it will become clear that our results are robust to choosing different control groups.

In Table 5.1 we compare treatment and control groups within 5 kilometers of distance. It can be seen that polling stations in each group look very similar in terms of past vote share, size of electorate and gender, age, education and marital status profiles. The same comparison is done for distance greater than 5 kilometers and presented in Tables C1-C7, in Appendix B. As expected, when we increase the distance to build control groups, treated and non-treated polling stations start to differ significantly, and our empirical strategy is not valid.

In the next section, we present the results using our preferred specifications. Analogous arguments can be used looking at alternative specifications, which we present in the following section.

\section{2}

\section{Main Results}

In Table 5.2, we report the estimates of Equation 5-1 using different treatment status. In Panel A, we report estimates using treatment variables built by taking polling stations that get sponsored FM radio signal coming from any municipality, either the municipality where the polling stations are located or not. In these exercises, we first use a dummy that indicates whether the polling station gets at least one sponsored signal. We report the results in columns 1 and 2. Using this same treatment variable, we estimate the coefficient of interest using matching, reporting the results in column 3 . We match each sponsored polling station to all polling stations in the control group within 5 kilometers. We also do the matching using the same variables we include as controls in Equation 5-1. Next, we use as a treatment variable 
one that indicates how many sponsored signals the polling station gets. The results are reported in columns 4 and 5. Lastly, in columns 6 and 7, we report the estimates using the mean spending per voter in each FM radio station the polling station gets signal from. In columns 2, 5 and 7, we include polling station level controls in the right-hand side of the regression.

In Panel B of Table 5.2, we report analogous estimates using only radio signals that come from another municipality, except for the spending per capita specification. In all specifications mentioned above, we use as dependent variable the share ( 0 to 1 ) of votes for PT in the first round of the 2014 presidential election.

From the proposed exercises, we can conclude that there seems to be no impact of financing radio stations through advertising on votes. When using as treatment variable a dummy for any sponsored signal and sponsored signal from another municipality, looking at specifications that include polling station level controls, the regression estimates are -0.016 and 0.01 respectively, both statistically non-distinguishable from zero. When using matching, the analogous coefficients are -0.01 and 0.015 , also statistically not different from zero.

When using as a treatment variable the number of signals received, the results stand. The coefficients are very similar and, again, not statistically different from zero when including polling station characteristics in the regressions.

Finally, when using spending per capita, the effect we estimate is positive and statistically significant. In particular, in column 7 , the coefficient is approximately 0.88. which means that one thousand additional Brazilian reais per capita on average buy 88 percentage points of vote share for the government. As the mean spending per capita in our sample is around $\mathrm{R} \$ 0.1$, the size of this effect is considerably small.

\section{3}

\section{Robustness Checks}

In the section above, we presented our preferred specifications, which use as control group the polling stations that get no radio signal and are up to $5 \mathrm{~km}$ apart from the sponsored ones. Here we briefly present the same exercises proposed before, but now using other control groups, namely the one with polling station that gets non-sponsored FM radio signal and the one that combines the two previous control groups, and gathering control observations using greater distances.

In Tables C9-C15, we compare characteristics of sponsored and nonsponsored polling stations 5, 10, 15, 20, 25, 30, 40 and 50km apart from each 
other, respectively. In Tables C16-C23, we do the same taking both control groups (no signal and non-sponsored) together. As before, for small distances, control and treated groups look similar in observables, but as we gather control observations further and further away from the treated ones, they start to differ significantly.

In Tables C24 and C26, we report regression estimates using as treatment a dummy for any sponsored signal and control group non-sponsored and both no signal and non-sponsored polling stations respectively. In Tables C27 and C29 we do the analogous using as a treatment variable a dummy for signal from other municipality. In Tables C30, C32, C33 and C35, we use the total number of signals. Finally, inC36 we report regressions estimates using the mean spending per capita.

In all those tables, even columns contain estimates using polling station controls and in columns 1-2, 3-4, 5-6, 7-8, 9-10, 11-12, 13-14 and 15-16 we report the regressions using no-signal controls within 5, 10, 15, 20, 25, 30, 40 and 50 kilometers from the treated polling stations respectively.

In Tables C39 and C40, we report the matching estimates using different control groups and distances. In those tables, columns 1, 4, 7, 10, 13, 16, 19 and 22 report the estimates using as a control group polling stations that get non-sponsored signal. In columns 2, 5, 8, 11, 14, 17, 20 and 23, we use only polling stations that get no signal as controls. Finally, in columns 3, 6, 9, 12, 15, 18, 21 and 24, we use both control groups together. The conclusions are very similar to those presented above, using regression estimates.

Using different control groups under short distances does not change our conclusions. As mentioned before, when gathering control observations further away from the treated ones, treatment and control groups start to systematically differ in observables, which indicates that the two groups are not comparable and the regression and matching estimates are not the causal impact of ads on votes we wish to retrieve, so the coefficients of interest start to be (still mostly negative and) statistically different from zero. We interpret these specifications as capturing something similar to what was presented in our first exercise using municipality level data: when using invalid control groups, there are probably other (potentially both observable and nonobservable) factors that determine PT's vote share and ad placement decisions. 


\begin{tabular}{|c|c|c|c|}
\hline \multicolumn{4}{|c|}{ Within $5 \mathrm{~km}$} \\
\hline & No-signal & Sponsored & diff.p-value \\
\hline \multirow[b]{3}{*}{ Distance to closest sponsored AM station } & $\begin{array}{c}0.512 \\
(0.008)\end{array}$ & $\begin{array}{c}0.523 \\
(0.021)\end{array}$ & 0.626 \\
\hline & $\begin{array}{c}0.573 \\
(0.007)\end{array}$ & $\begin{array}{c}0.583 \\
(0.020)\end{array}$ & 0.674 \\
\hline & $\begin{array}{l}15.324 \\
(0.908)\end{array}$ & $\begin{array}{l}23.637 \\
(3.123)\end{array}$ & 0.004 \\
\hline Total electorate & $\begin{array}{c}1814.546 \\
(48.824)\end{array}$ & $\begin{array}{l}1606.584 \\
(133.720)\end{array}$ & 0.173 \\
\hline Male share of electorate & $\begin{array}{c}0.481 \\
(0.001)\end{array}$ & $\begin{array}{c}0.480 \\
(0.004)\end{array}$ & 0.860 \\
\hline 16-17 year old share of electorate & $\begin{array}{c}0.017 \\
(0.001)\end{array}$ & $\begin{array}{c}0.021 \\
(0.003)\end{array}$ & 0.040 \\
\hline 18-24 year old share of electorate & $\begin{array}{c}0.173 \\
(0.003)\end{array}$ & $\begin{array}{c}0.194 \\
(0.013)\end{array}$ & 0.071 \\
\hline 25-34 year old share of electorate & $\begin{array}{c}0.233 \\
(0.003)\end{array}$ & $\begin{array}{c}0.235 \\
(0.008)\end{array}$ & 0.800 \\
\hline $35-44$ year old share of electorate & $\begin{array}{c}0.190 \\
(0.002)\end{array}$ & $\begin{array}{c}0.186 \\
(0.006)\end{array}$ & 0.595 \\
\hline 45-59 year old share of electorate & $\begin{array}{c}0.222 \\
(0.002)\end{array}$ & $\begin{array}{c}0.207 \\
(0.007)\end{array}$ & 0.041 \\
\hline 60-69 year old share of electorate & $\begin{array}{c}0.089 \\
(0.001)\end{array}$ & $\begin{array}{c}0.085 \\
(0.004)\end{array}$ & 0.338 \\
\hline \multirow[b]{3}{*}{ Complete elementary school share of electorate } & $\begin{array}{c}0.078 \\
(0.002)\end{array}$ & $\begin{array}{c}0.071 \\
(0.006)\end{array}$ & 0.342 \\
\hline & $\begin{array}{c}0.478 \\
(0.005)\end{array}$ & $\begin{array}{c}0.494 \\
(0.014)\end{array}$ & 0.300 \\
\hline & $\begin{array}{c}0.243 \\
(0.003)\end{array}$ & $\begin{array}{c}0.247 \\
(0.009)\end{array}$ & 0.654 \\
\hline Complete high-school share of electorate & $\begin{array}{c}0.163 \\
(0.004)\end{array}$ & $\begin{array}{c}0.153 \\
(0.010)\end{array}$ & 0.426 \\
\hline Married share of electorate & $\begin{array}{c}0.299 \\
(0.003)\end{array}$ & $\begin{array}{c}0.303 \\
(0.011)\end{array}$ & 0.688 \\
\hline Divorced share of electorate & $\begin{array}{c}0.023 \\
(0.001)\end{array}$ & $\begin{array}{c}0.023 \\
(0.002)\end{array}$ & 0.772 \\
\hline Single share of electorate & $\begin{array}{c}0.660 \\
(0.003)\end{array}$ & $\begin{array}{c}0.657 \\
(0.012)\end{array}$ & 0.809 \\
\hline $\mathrm{N}$ & 800 & 89 & \\
\hline
\end{tabular}

Table 5.1: Polling station characteristics: balance test. Control group: no signal within $5 \mathrm{~km}$

Notes: This table compares characteristics of polling stations that get any sponsored signal (treated) to those of ones that get no signal (control), conditional on treated and control being up to 5 kilometers apart from each other. For each treated polling station, there may be more than one associated control. The last column reports the p-value of the mean difference t-test. The variables are past PT vote share (2010, rounds 1 and 2), polling station distance from closest sponsored AM radio station's antenna, total electorate and polling station's electorate shares of male, 16-17, 18-24, 25-34, 35-44, 45-59 and 60-69 years old, illiterate, incomplete elementary school, complete elementary school (or incomplete high-school) and complete high-school (or incomplete college), married, divorced and single. 


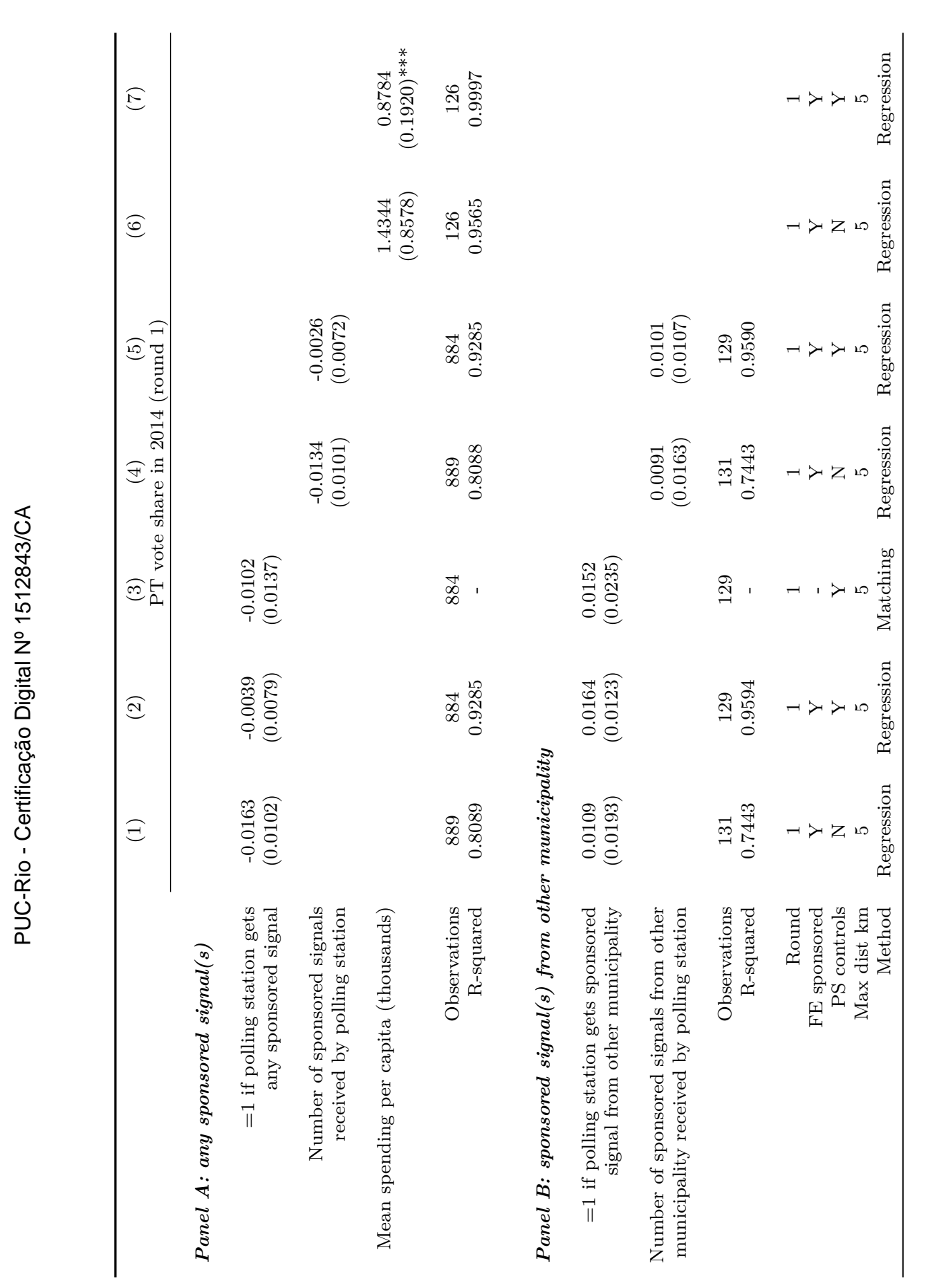

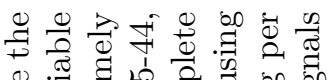

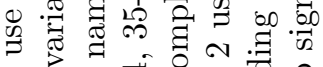

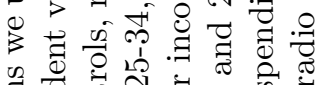

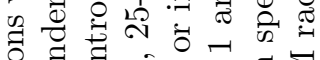

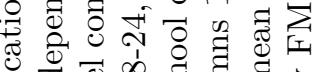

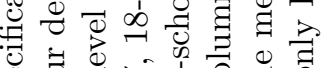

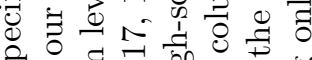

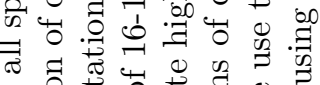

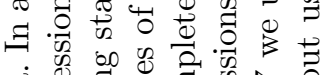

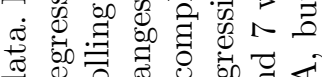

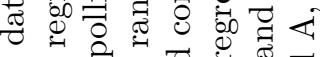

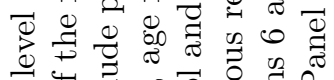

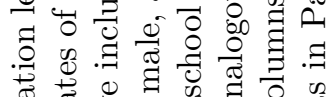

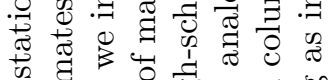

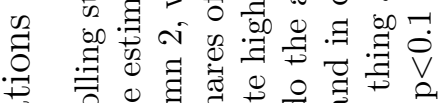

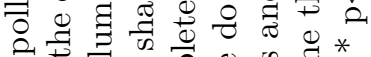

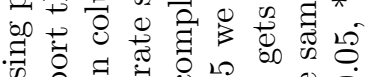

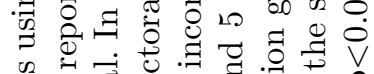

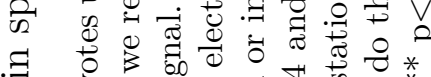
范 a

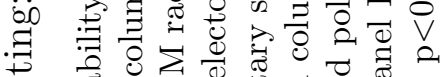
等 б

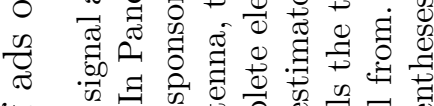

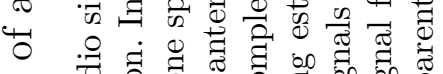
प

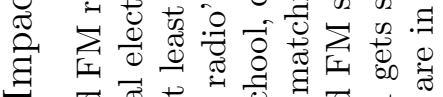

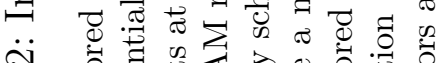
is

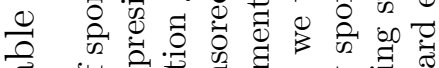
to 5 is

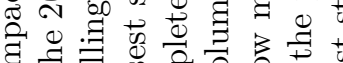

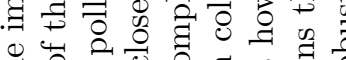
嵌

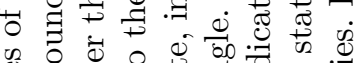

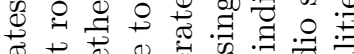

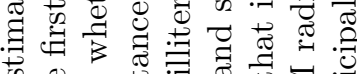
के o

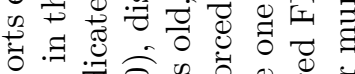

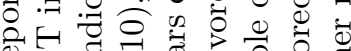

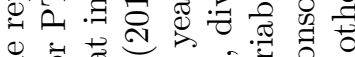

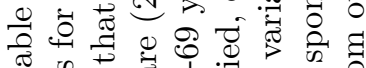

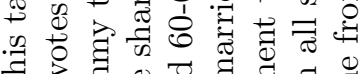
点考

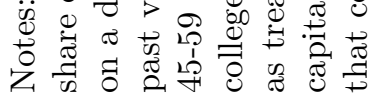




\section{6 \\ Conclusion}

Many governments around the world advertise, but there is little evidence about the motivations and the effects of advertising decisions by public bodies. In this paper, we assemble a unique and extensive data set on advertising spending by the Brazilian federal government to shed light on the behavior of public advertisers and on the impacts of advertising on electoral outcomes.

We first regress federal spending on ads with past votes in the local level. Based on the literature on distributive politics, we investigate whether the incumbent party on the presidency spends more money on municipalities where it received fewer votes in the past. Our findings suggest that this is what happens and the relation is stronger when taking money spent by ministries and on low range media. This is compatible with public bodies more subject to political interference (ministries in comparison to public companies) trying to gather votes in the local level using media vehicles more suitable for that.

Next, we explore features of radio technology to estimate the effect of advertising on voting. The party that holds the presidency may want to explore its incumbency advantage by using the official ad budget to finance media outlets and induce media bias. Using a cross-sectional subset of our data and running the analysis on the polling station level, we find no impact of public advertising on voting for the incumbent party. Our findings are robust to different specifications and control groups.

Although we argue that pouring money into media vehicles may induce media bias, we do not provide any explicit evidence on that. Thus, our story is close to what Di (22) document when studying the case of Argentinian newspapers. Besides having an empirical strategy that helps us state the causal effect of being exposed to sponsored media on electoral outcomes, the lack of content analysis prevent us from stating that media bias is actually in place. In this dimension, our work also differs from the one of (13), as we cannot point out specific bias or ideology alignment of media outlets and its role on voter persuasion. We also argue that the ads placed by the government are not able to persuade the voters directly, as the campaigns promoted by the federal government do not carry explicit political or partisan content.

Some limitations in this last exercise, however, should be mentioned and 
properly addressed in the near future. The prediction of FM radio coverage is an obvious issue that can be improved using more sophisticated models that take into account terrain profile (e.g., the Longley-Rice, commonly used in similar applications). There is also space for improving the geocoding process, although there are some important data limitations. 


\section{References}

[1] GOLDEN, M.; MIN, B. Distributive politics around the world. Annu. Rev. Polit. Sci., v. 16, n. 1, p. 73-99, May 2013.

[2] DIXIT, A.; LONDREGAN, J. The determinants of success of special interests in redistributive politics. The Journal of Politics, v. 58, n. 4, p. 1132-1155, 1996.

[3] DIXIT, A.; LONDREGAN, J. Ideology, tactics, and efficiency in redistributive politics. The Quarterly Journal of Economics, v. 113, n. 2, p. 497-529, 1998.

[4] LINDBECK, A.; WEIBULL, J. W. Balanced-budget redistribution as the outcome of political competition. Public Choice, v. 52, n. 3, p. 273-297, 1987.

[5] PERSSON, T.; TABELLINI, G. Political economics: Explaining economic policy. 1st. ed., Zeuthen Lectures. The MIT Press, 2000.

[6] COX, G. W. Swing voters, core voters, and distributive politics. In: SHAPIRO, I.; STOKES, S. C.; WOOD, E. J.; KIRSHNER, A. S. (Eds.) Political Representation: Cambridge: Cambridge University Press, 2010. p. 342-357-.

[7] WARD, H.; JOHN, P. Targeting benefits for electoral gain: Constituency marginality and the distribution of grants to english local authorities. Political Studies, v. 47, n. 1, p. 32-52, Mar. 1999.

[8] ARULAMPALAM, W.; DASGUPTA, S.; DHILLON, A.; DUTTA, B. Electoral goals and center-state transfers: $A$ theoretical model and empirical evidence from india. Journal of Development Economics, v. 88, n. 1, p. 103-119, Jan. 2009.

[9] BESLEY, T.; BURGESS, R. The political economy of government responsiveness: Theory and evidence from india. The Quarterly Journal of Economics, v. 117, n. 4, p. 1415-1451, Nov. 2002.

[10] ZUCCO, C. When payouts pay off: Conditional cash transfers and voting behavior in brazil 2002-10. American Journal of Political Science, v. 57, n. 4, p. 810-822, Oct. 2013. 
[11] DELlaVIGNA, S.; GeNTZKOW, M. Persuasion: Empirical evidence. Annu. Rev. Econ., v. 2, n. 1, p. 643-669, Aug. 2010.

[12] ENIKOLOPOV, R.; PETROVA, M.; ZHURAVSKAYA, E. Media and political persuasion: Evidence from russia. The American Economic Review, v. 101, n. 7, p. 3253-3285, 2011.

[13] DELLAVIGNA, S.; KAPLAN, E. The fox news effect: Media bias and voting. The Quarterly Journal of Economics, v. 122, n. 3, p. 1187-1234, Aug. 2007.

[14] GENTZKOW, M.; PETEK, N.; SHAPIRO, J. M.; SINKINSON, M. Do newspapers serve the state? incumbent party influence on the us press, 18691928. Journal of the European Economic Association, v. 13, n. 1, p. 29-61, Feb. 2015.

[15] BESLEY, T.; PRAT, A. Handcuffs for the grabbing hand? media capture and government accountability. American Economic Review, v. 96, n. 3, p. 720-736, 2006.

[16] GEHLBACH, S.; SONIN, K. Government control of the media. Journal of Public Economics, v. 118, p. 163-171, Oct. 2014.

[17] DELlaVignA, S.; DURANTE, R.; KNIGHT, B.; LA FERRARA, E. Marketbased lobbying: Evidence from advertising spending in italy. American Economic Journal: Applied Economics, v. 8, n. 1, p. 224-56, 2016.

[18] BOOMGAARDEN, H. G.; EBERL, J.-M.; WAGNER, M. Party advertising in newspapers. Journalism Studies, p. 1-21, Oct. 2016.

[19] ELLMAN, M.; GERMANO, F. What do the papers sell? a model of advertising and media bias. The Economic Journal, v. 119, n. 537, p. 680-704, Apr. 2009.

[20] REUTER, J.; ZITZEWITZ, E. Do ads influence editors? advertising and bias in the financial media. The Quarterly Journal of Economics, v. 121, n. 1, p. 197-227, Feb. 2006.

[21] GAMBARO, M.; PUGLISI, R. What do ads buy? daily coverage of listed companies on the italian press. European Journal of Political Economy, v. 39, p. 41-57, Sept. 2015.

[22] DI TELLA, R.; FRANCESCHELLI, I. Government advertising and media coverage of corruption scandals. American Economic Journal: Applied Economics, v. 3, n. 4, p. 119-51, 2011. 
[23] SZEIDLY, A.; SZUCSZ, F. Variation in political favoritism: Theory and evidence from the hungarian media. February 2016.

[24] DEllaVignA, S.; ENIKOlOPOV, R.; MIRONOVA, V.; PETROVA, M.; ZHURAVSKAYA, E. Cross-border media and nationalism: Evidence from serbian radio in croatia. American Economic Journal: Applied Economics, v. 6, n. 3, p. 103-32, 2014.

[25] YANAGIZAWA-DROTT, D. Propaganda and conflict: Evidence from the rwandan genocide. The Quarterly Journal of Economics, v. 129, n. 4, p. 1947-1994, Nov. 2014.

[26] BOAS, T. C. Mass media and politics in latin america. January 2012.

[27] FERRAZ, C.; FINAN, F. Exposing corrupt politicians: The effects of brazil's publicly released audits on electoral outcomes*. The Quarterly Journal of Economics, v. 123, n. 2, p. 703-745, May 2008.

[28] BOAS, T. C.; HIDALGO, F. D. Controlling the airwaves: Incumbency advantage and community radio in brazil. American Journal of Political Science, v. 55, n. 4, p. 869-885, Oct. 2011.

[29] BOAS, T. C. Media barons on the ballot: Politically-controlled broadcasting in brazil. March 2014.

[30] DA SILVEIRA, B. S.; DE MELLO, J. M. P. Campaign advertising and election outcomes: Quasi-natural experiment evidence from gubernatorial elections in brazil. The Review of Economic Studies, v. 78, n. 2, p. 590-612, Apr. 2011.

[31] AKHMEDOV, A.; ZHURAVSKAYA, E. Opportunistic political cycles: Test in a young democracy setting. The Quarterly Journal of Economics, v. 119, n. 4, p. 1301-1338, Nov. 2004.

[32] IMBENS, G.; ZAJONC, T. Regression discontinuity design with multiple forcing variables. April 2009.

[33] KEELE, L. J.; TITIUNIK, R. Geographic boundaries as regression discontinuities. Political Analysis, v. 23, n. 1, p. 127-155, Jan. 2014.

[34] KEELE, L.; TITIUNIK, R. Natural experiments based on geography. Political Science Research and Methods, v. 4, n. 1, p. 65-95, January 2016.

[35] PAPAY, J. P.; WILLETT, J. B.; MURNANE, R. J. Extending the regressiondiscontinuity approach to multiple assignment variables. Journal of Econometrics, v. 161, n. 2, p. 203-207, Apr. 2011. 
[36] WONG, V. C.; STEINER, P. M.; COOK, T. D. Analyzing regressiondiscontinuity designs with multiple assignment variables. Journal of Educational and Behavioral Statistics, v. 38, n. 2, p. 107-141, Apr. 2013. 
A

\section{Appendix}

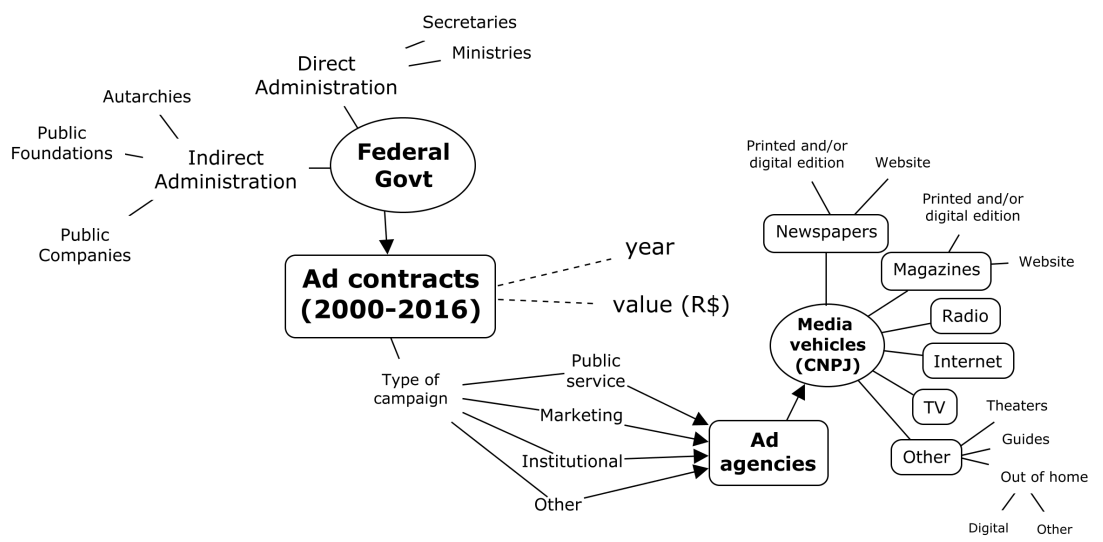

Figure A1: Government advertising data

Notes: This figure displays a visual scheme of the Instituto para Acompanhamento de Publicidade (IAP) data on federal government advertising in Brazil

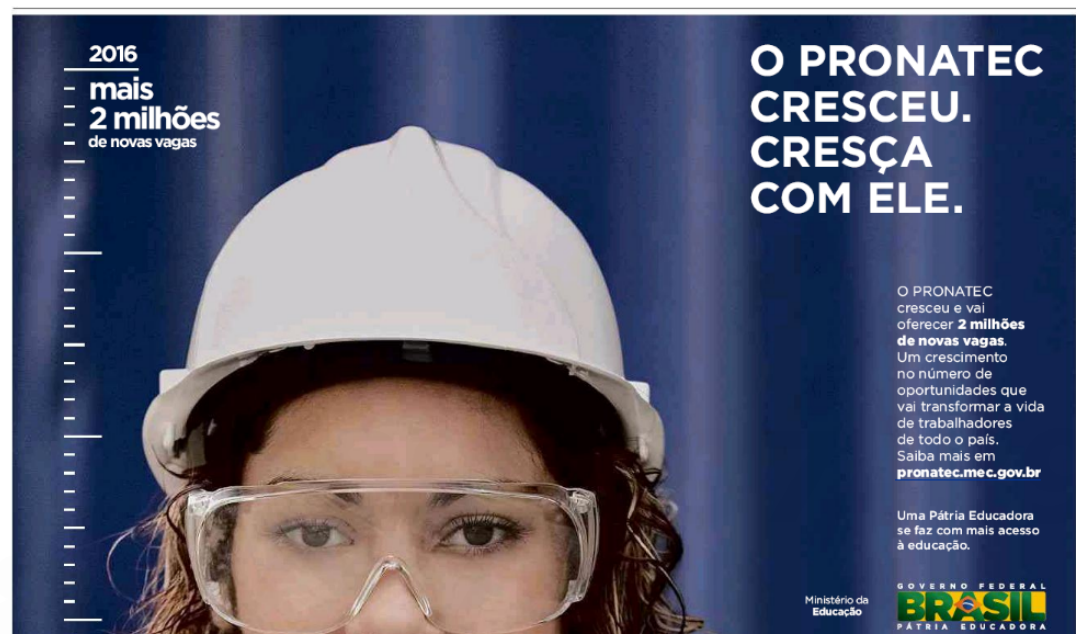

Figure A2: Ad sample: Ministry of Education

Notes: This figure displays a sample of a piece of advertisement place by the Ministry of Education's training program, PRONATEC, on Folha de S. Paulo newspaper (April 12th, 2016 edition) 


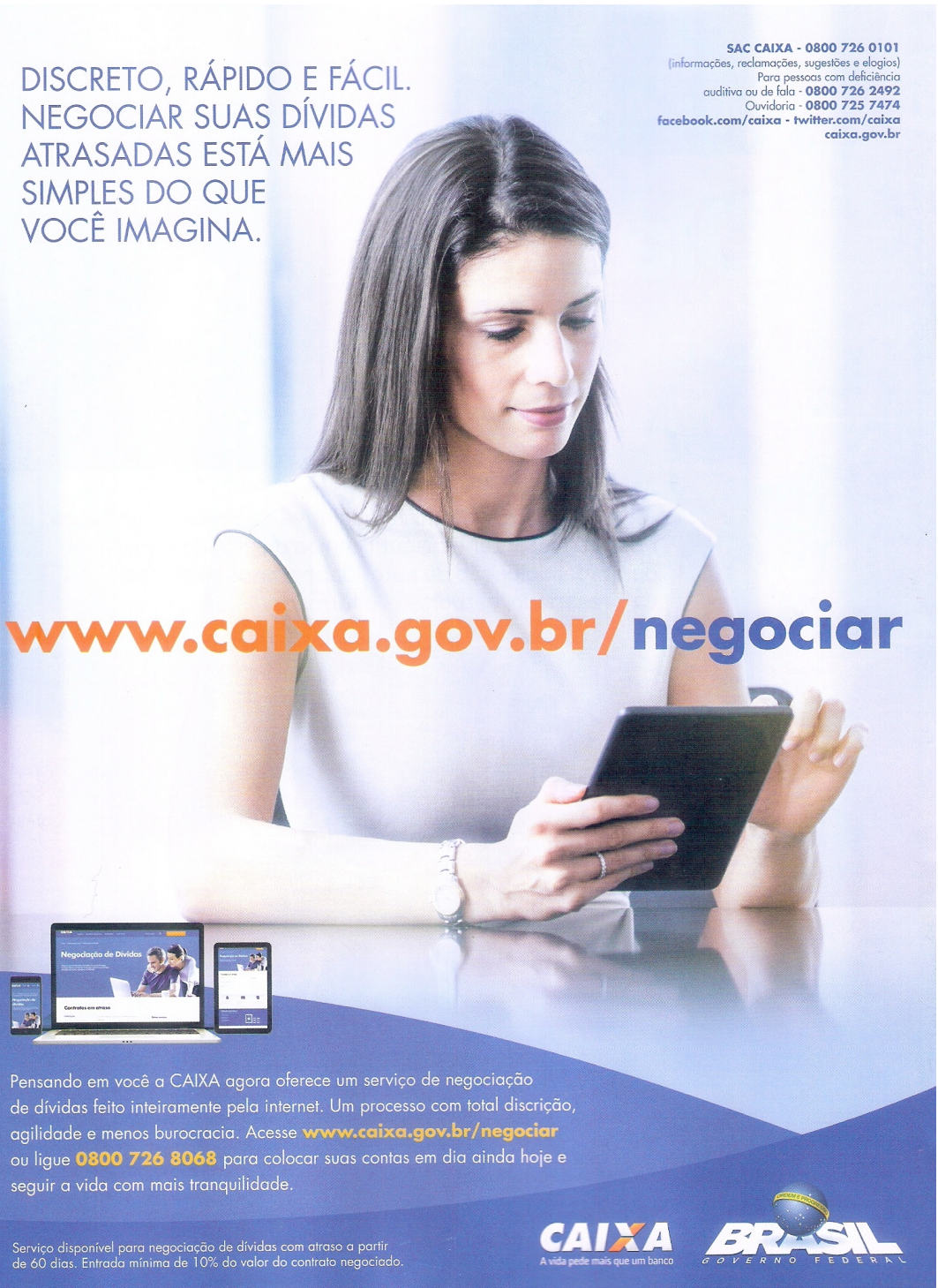

Figure A3: Ad sample: Caixa

Notes: This figure displays a sample of a piece of advertisement place by Caixa Econômica Federal, a public bank, on Carta Capital magazine (July 13th, 2016 edition) 


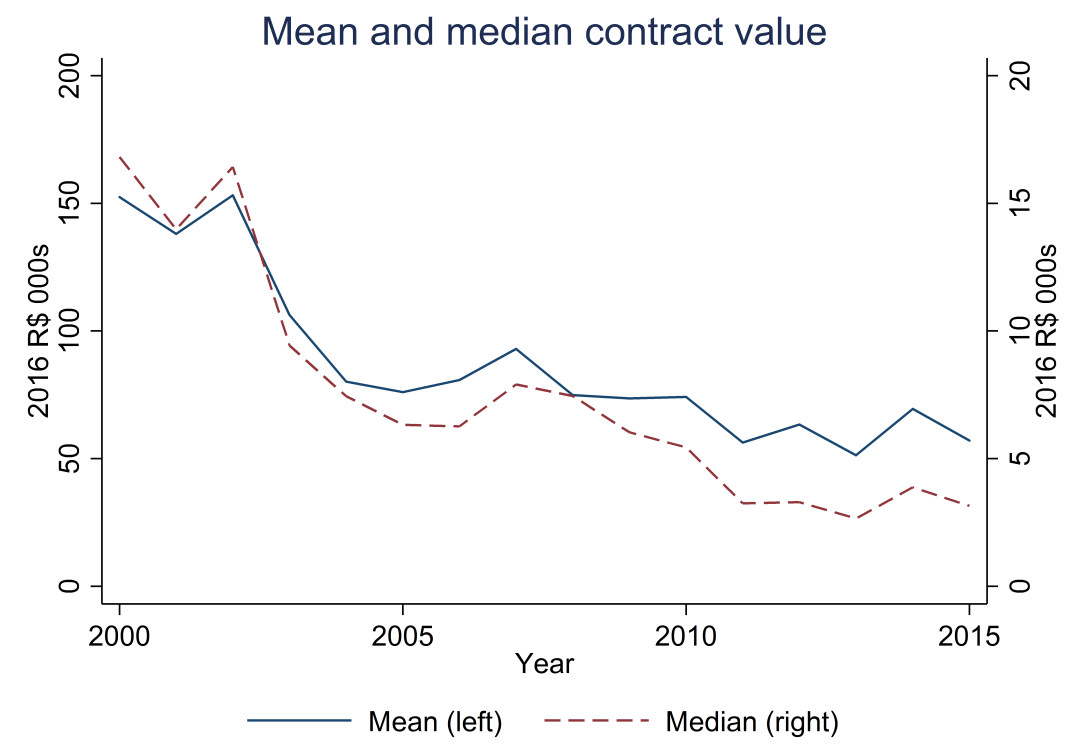

Figure A4: Mean and median contract values, all media: 2000-2015

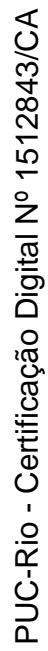

Notes: This figure plots mean and median values spent by federal government entities on media vehicles yearly from 2000 to 2015. The values are in thousands of 2016 Brazilian Reais $(\mathrm{R} \$)$. The mean in plotted on the left side and the median on the right one.

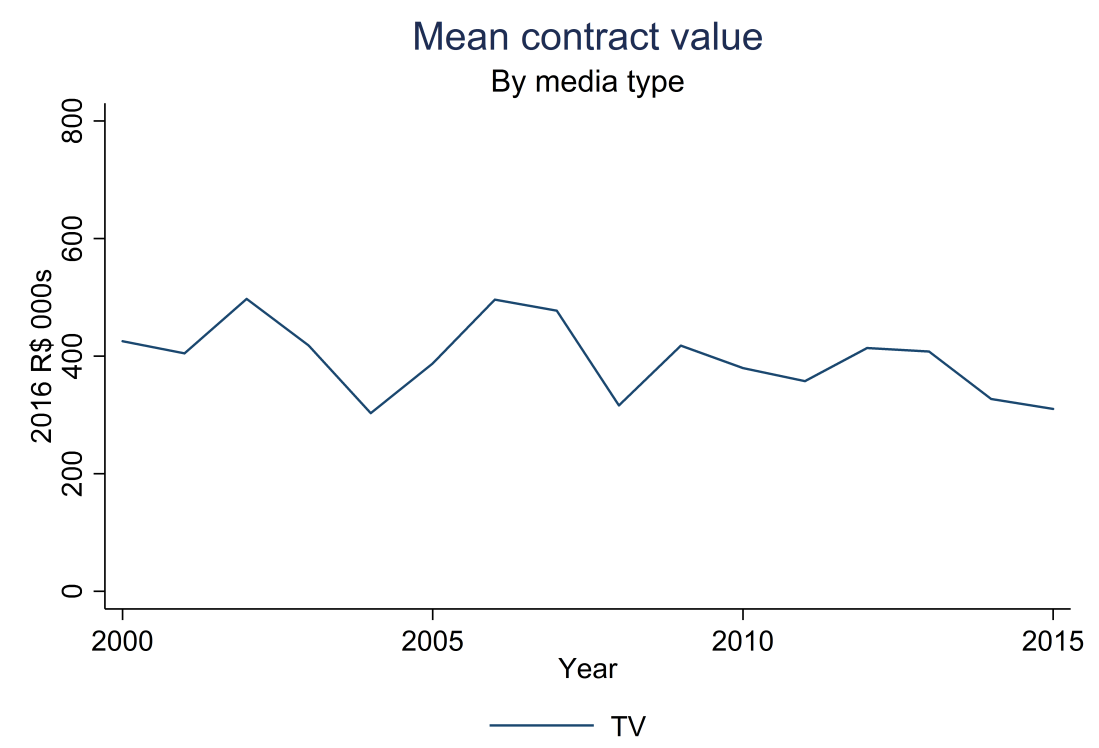

Figure A5: TV mean and median contract values: 2000-2015

Notes: This figure plots mean values spent by federal government entities on TV media vehicles yearly from 2000 to 2015. The values are in thousands of 2016 Brazilian Reais (R\$). 


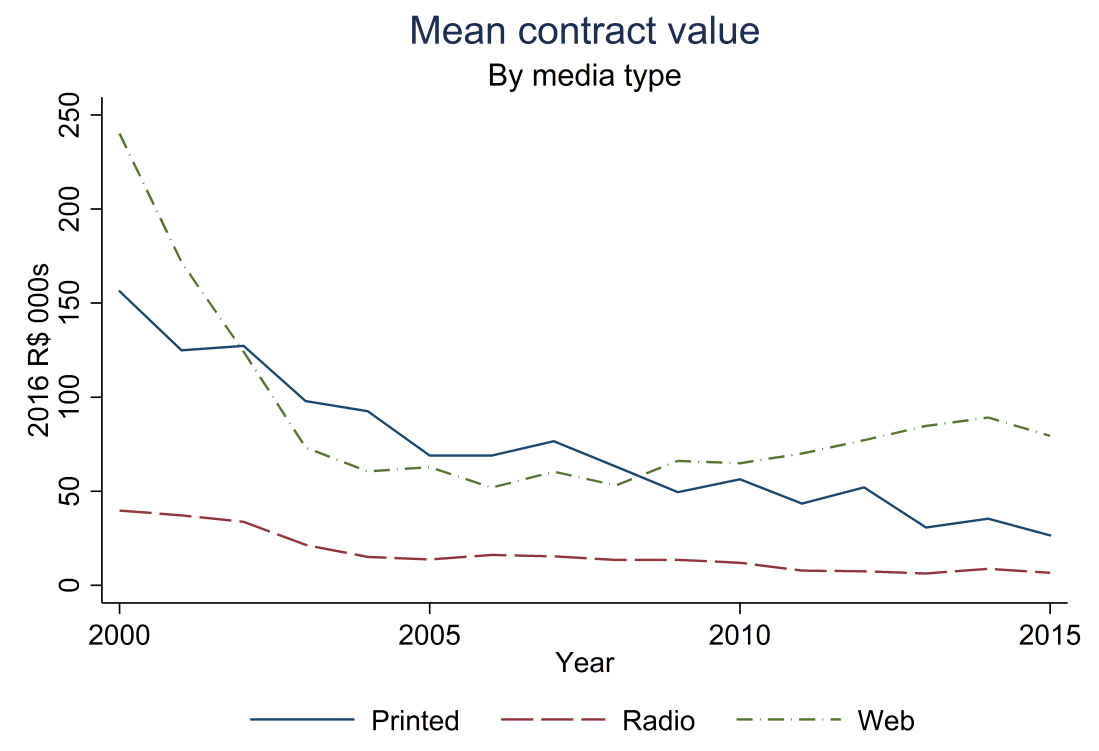

Figure A6: Printed, radio and web mean and median contract values: 2000-2015

Notes: This figure plots mean values spent by federal government entities on printed media, radio and internet vehicles yearly from 2000 to 2015. The values are in thousands of 2016 Brazilian Reais $(\mathrm{R} \$)$.

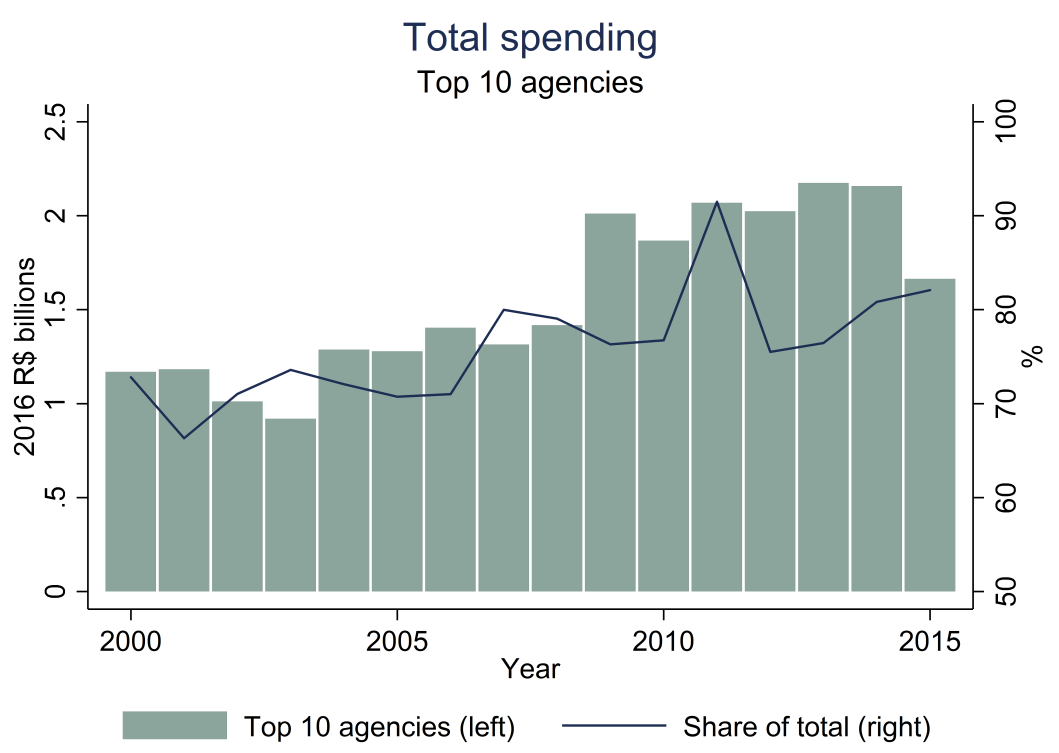

Figure A7: Spending on revenue top 10 ad agencies: 2000-2015

Notes: This figure plots total (in billions of 2016 Brazilian Reais, $\mathrm{R} \$$ ) and share of total spent by federal government entities in the top 10 ad agencies in each year from 2000 to 2015 . 
B

\section{Appendix}

\begin{tabular}{|c|c|c|c|c|c|c|}
\hline \multirow[b]{3}{*}{$\mathrm{PT}$ vote share } & (1) & $(2)$ & (3) & (4) & (5) & (6) \\
\hline & \multicolumn{6}{|c|}{ log (Total year spending (exc TV) per capita) } \\
\hline & $\begin{array}{c}-0.046 \\
(0.004)^{* * *}\end{array}$ & $\begin{array}{c}-0.046 \\
(0.004)^{* * *}\end{array}$ & $\begin{array}{c}-0.046 \\
(0.004)^{* * *}\end{array}$ & $\begin{array}{c}-0.049 \\
(0.004)^{* * *}\end{array}$ & $\begin{array}{c}-0.049 \\
(0.004)^{* * *}\end{array}$ & $\begin{array}{c}-0.050 \\
(0.004)^{* * *}\end{array}$ \\
\hline$=1$ if $\mathrm{PT}$ mayor & & $\begin{array}{l}-0.006 \\
(0.154)\end{array}$ & $\begin{array}{l}-0.036 \\
(0.156)\end{array}$ & & $\begin{array}{l}-0.034 \\
(0.154)\end{array}$ & $\begin{array}{l}-0.060 \\
(0.156)\end{array}$ \\
\hline Observations & 7,916 & 7,907 & 7,831 & 7,916 & 7,907 & 7,831 \\
\hline R-squared & 0.648 & 0.648 & 0.642 & 0.647 & 0.646 & 0.641 \\
\hline Round & 1 & 1 & 1 & 2 & 2 & 2 \\
\hline FE Mun & $\mathrm{Y}$ & $\mathrm{Y}$ & $\mathrm{Y}$ & $\mathrm{Y}$ & $\mathrm{Y}$ & $\mathrm{Y}$ \\
\hline Mun. controls & $\mathrm{Y}$ & $\mathrm{Y}$ & $\mathrm{Y}$ & $\mathrm{Y}$ & $\mathrm{Y}$ & $\mathrm{Y}$ \\
\hline FE year & $\mathrm{Y}$ & $\mathrm{Y}$ & $\mathrm{Y}$ & $\mathrm{Y}$ & $\mathrm{Y}$ & $\mathrm{Y}$ \\
\hline Big cities & $\mathrm{Y}$ & Y & $\mathrm{N}$ & $\mathrm{Y}$ & Y & $\mathrm{N}$ \\
\hline $\mathrm{PT}$ vote share mean & 47.13 & 47.13 & 47.13 & 56 & 56 & 56 \\
\hline PT vote share sd & 15.93 & 15.93 & 15.93 & 15.77 & 15.77 & 15.77 \\
\hline
\end{tabular}

Table B1: Spending per capita (exc. TV) on election year: total

Notes: This table reports the relation between the federal government spending on ads and voting in the municipality level. It contains the output of regressions using 2002, 2006, 2010 and 2014 presidential election outcomes, election year spending per capita on ads (exc. TV) and municipality controls. In particular, in columns 1-3, we regress log of the year spending per capita on PT's vote share in round 1 . In columns $4-6$, we use round 2 outcomes. In columns 2 and 5 we include municipality controls, namely the log of GDP per capita and the $\log$ of the population in election years. Finally, in columns 3 and 6 we exclude the top $1 \%$ most populated cities. All regressions include time and municipality fixed effects. Robust standard errors in parentheses. ${ }^{* * *} \mathrm{p}<0.01, * * \mathrm{p}<0.05,{ }^{*} \mathrm{p}<0.1$. 


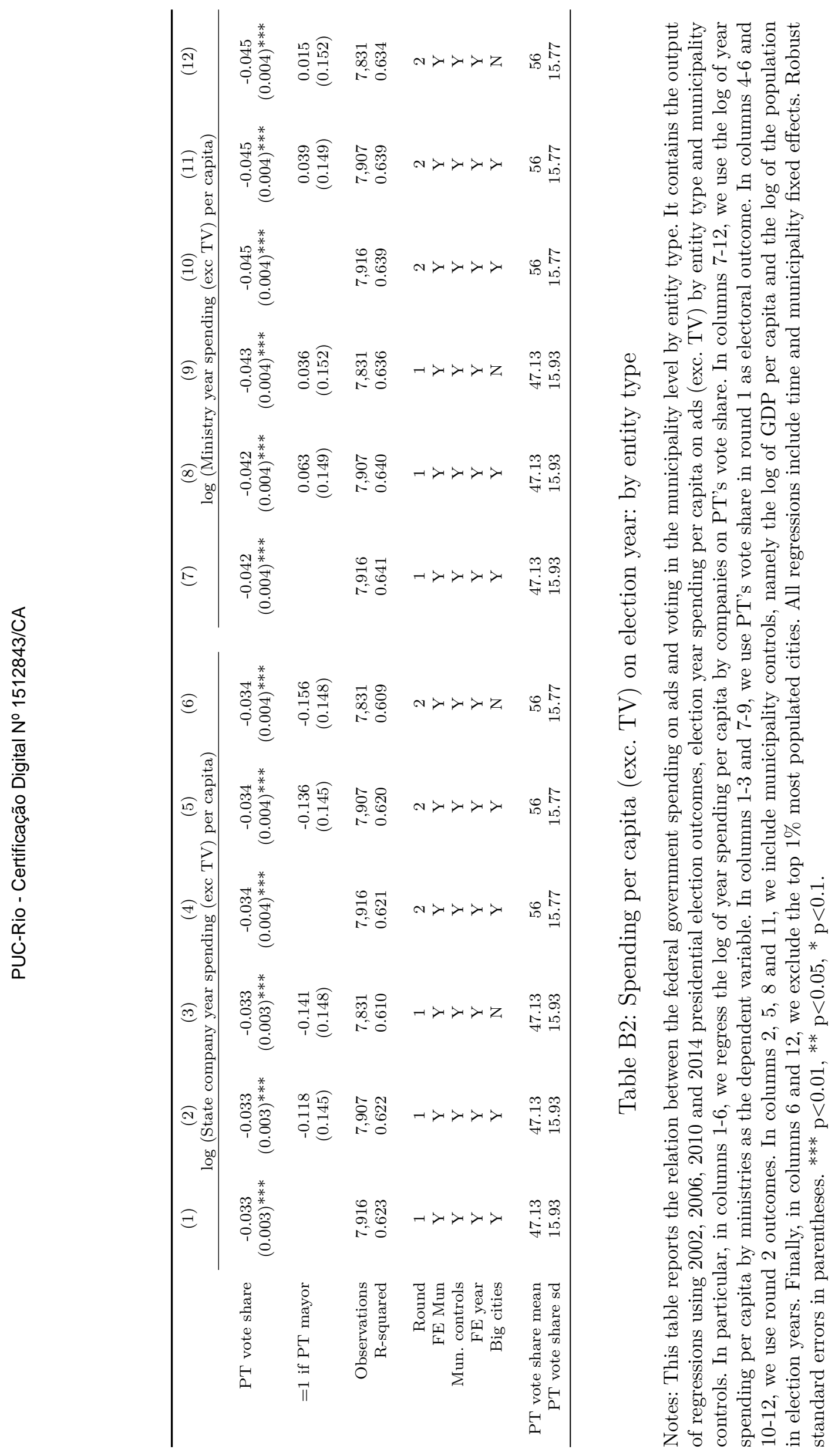



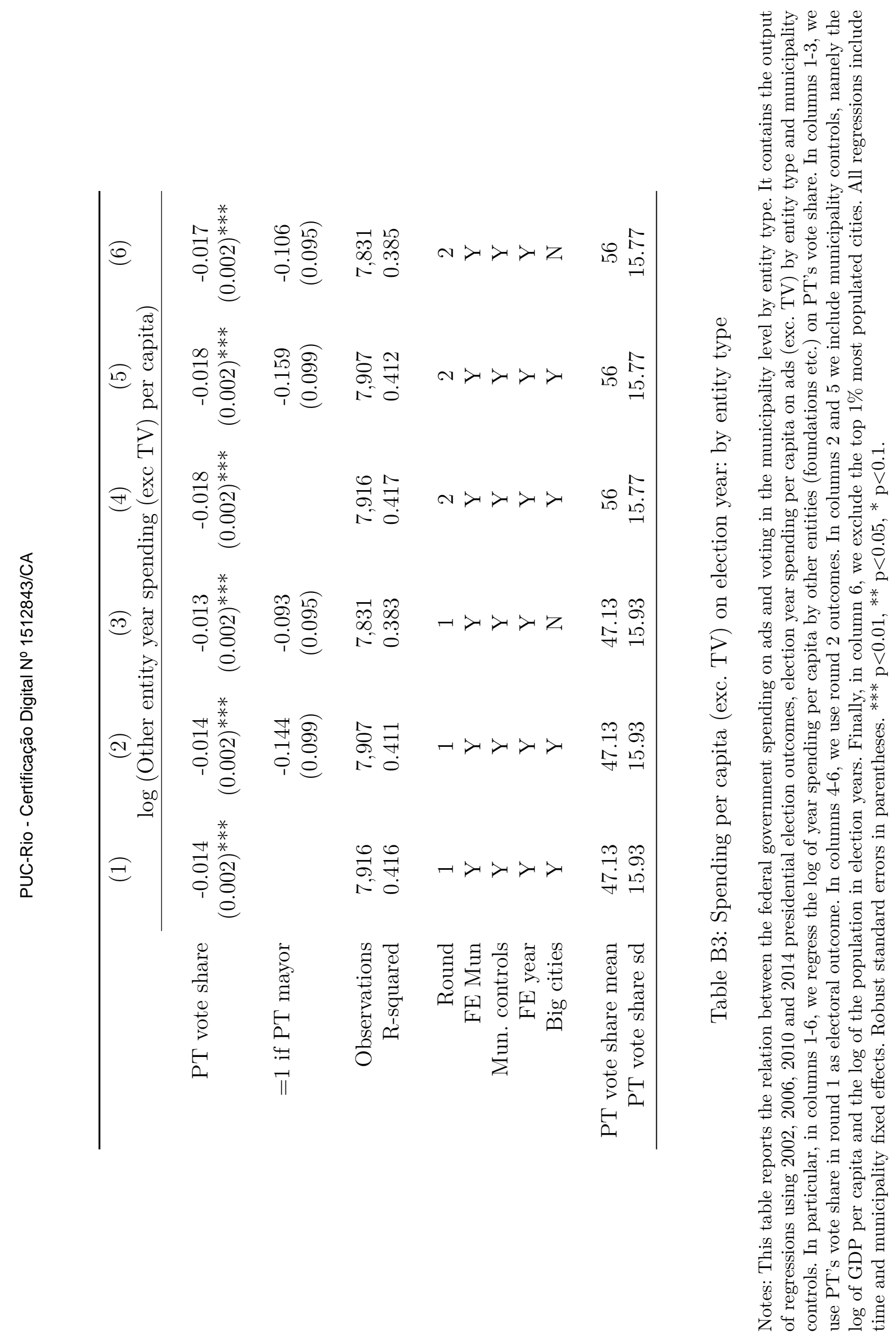


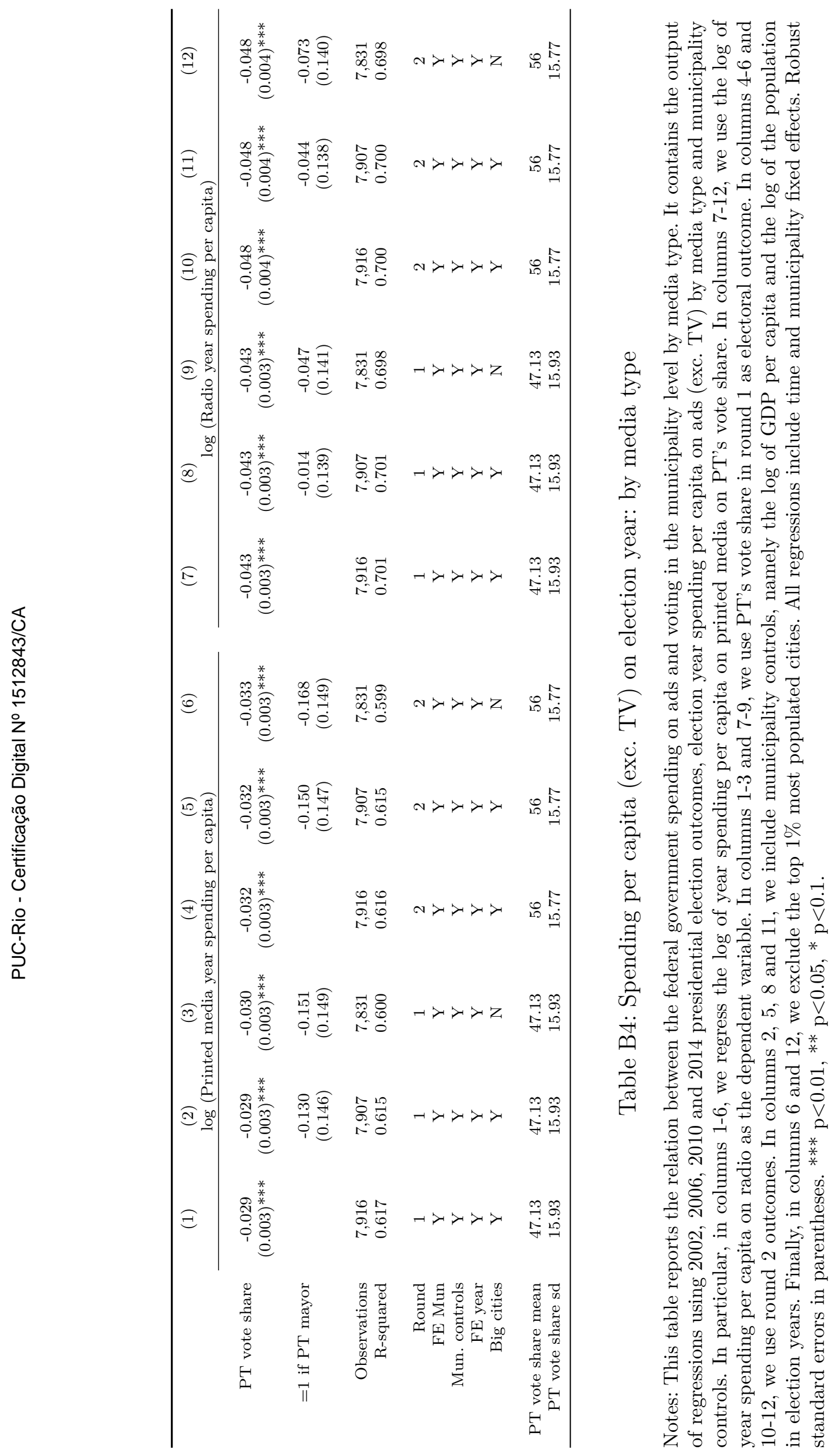




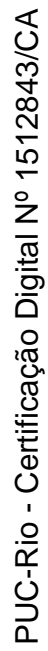

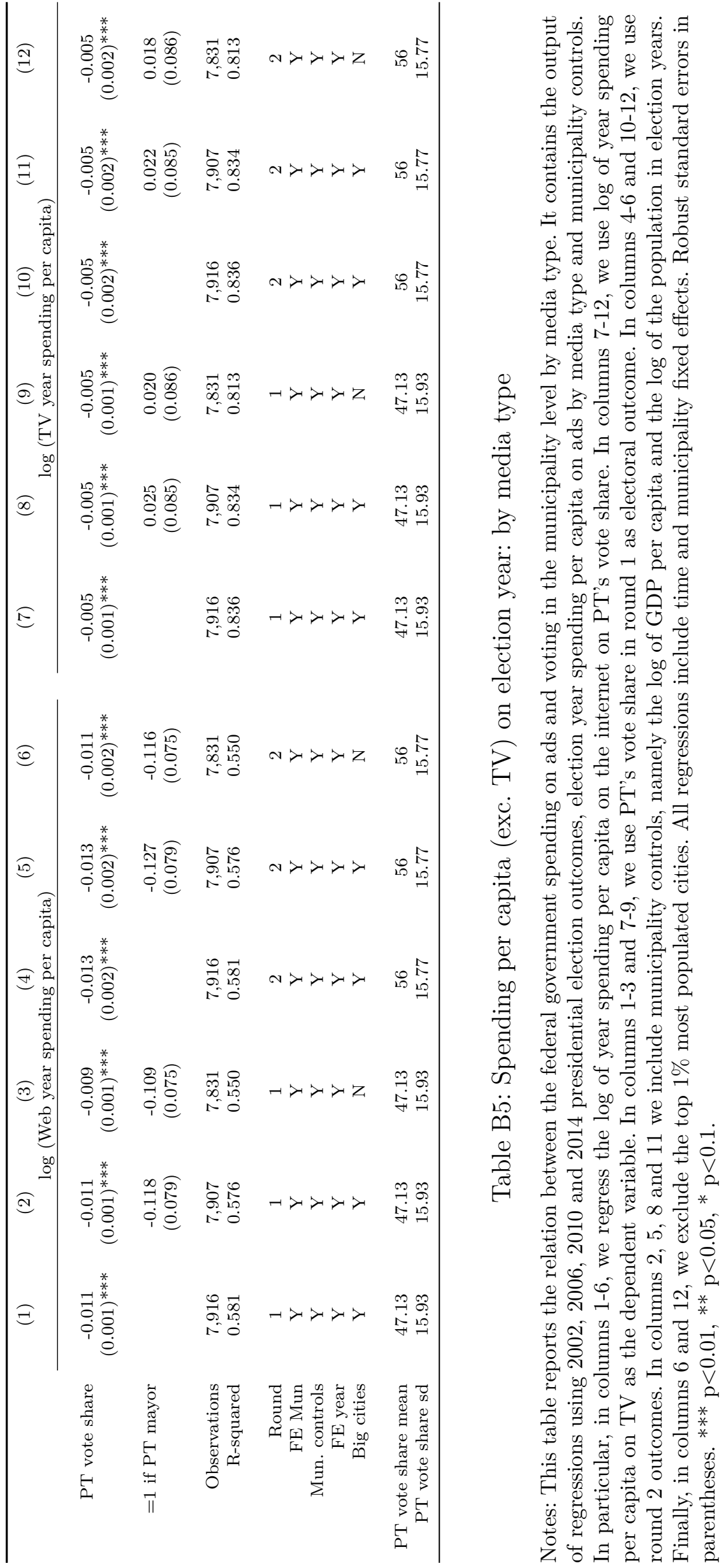



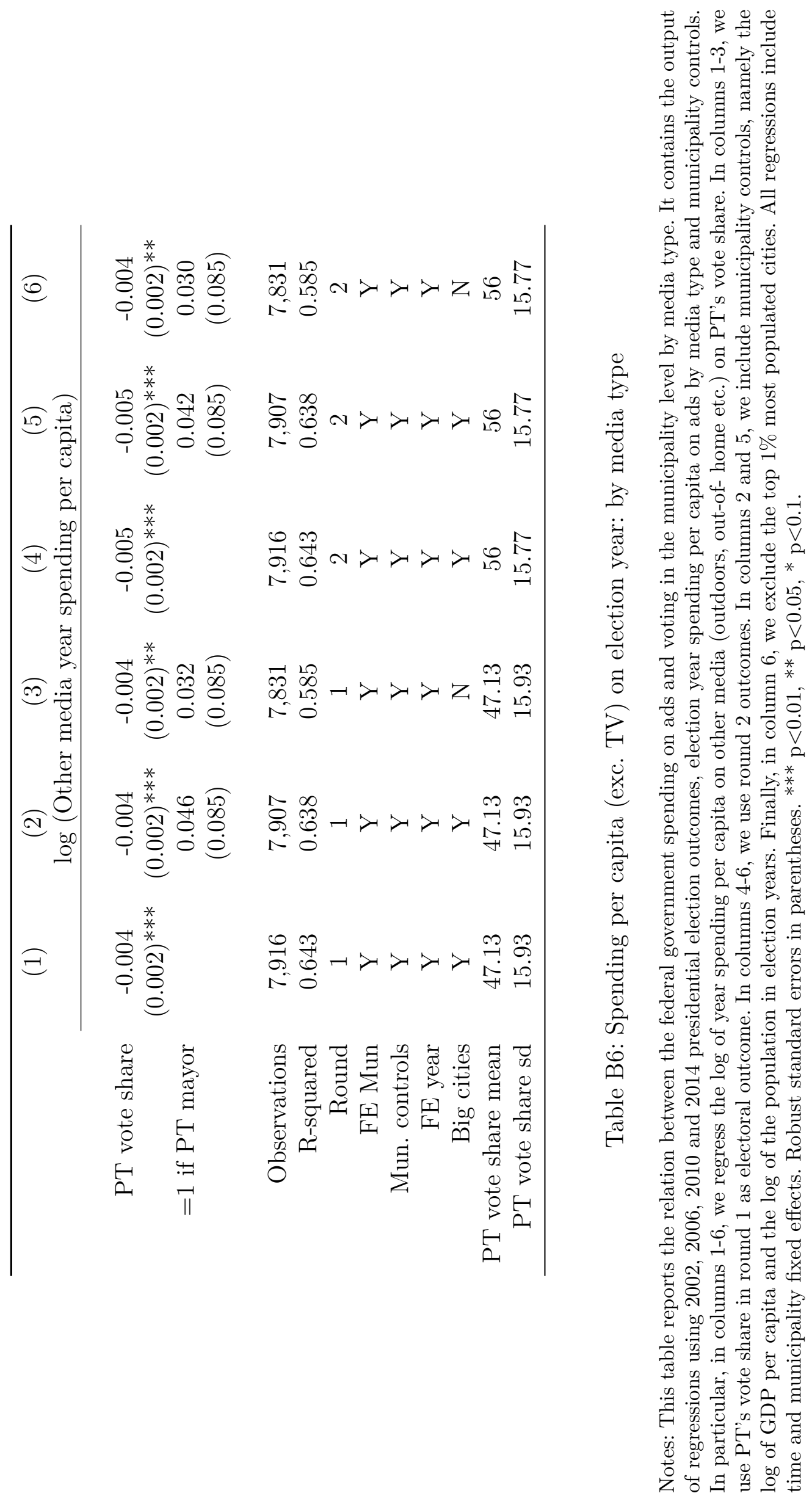
C

\section{Appendix}

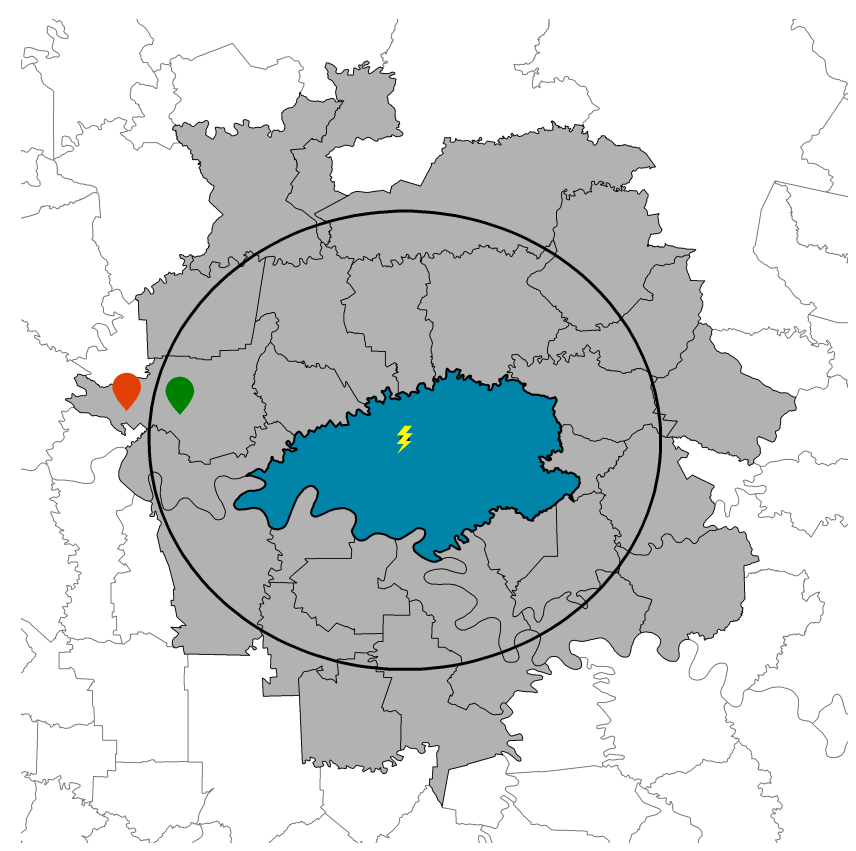

Figure C1: Ads on voting: empirical strategy illustration

Notes: This figure illustrates the general idea of our empirical strategy to assess the impact of government radio ads on voting. For each FM radio station (the yellow lighting in the center of the figure), we know the estimated range of signal coverage (dark circle). Treated polling stations are the furthest away from sponsored station that still get the signal. The associated control polling stations are those (potentially more than one) within a certain distance from the treated polling stations that do not get any sponsored signal. 


\begin{tabular}{|c|c|c|c|}
\hline \multicolumn{4}{|c|}{ Within $10 \mathrm{~km}$} \\
\hline & No-signal & Sponsored & diff.p-value \\
\hline \multirow[b]{3}{*}{ Distance to closest sponsored AM station } & $\begin{array}{c}0.506 \\
(0.006)\end{array}$ & $\begin{array}{c}0.513 \\
(0.017)\end{array}$ & 0.717 \\
\hline & $\begin{array}{c}0.568 \\
(0.006)\end{array}$ & $\begin{array}{c}0.566 \\
(0.016)\end{array}$ & 0.898 \\
\hline & $\begin{array}{l}16.306 \\
(0.633)\end{array}$ & $\begin{array}{l}21.203 \\
(2.004)\end{array}$ & 0.013 \\
\hline Total electorate & $\begin{array}{c}1735.159 \\
(39.300)\end{array}$ & $\begin{array}{l}1567.662 \\
(106.859)\end{array}$ & 0.162 \\
\hline Male share of electorate & $\begin{array}{c}0.483 \\
(0.001)\end{array}$ & $\begin{array}{c}0.485 \\
(0.003)\end{array}$ & 0.471 \\
\hline 16-17 years old share of electorate & $\begin{array}{c}0.017 \\
(0.001)\end{array}$ & $\begin{array}{c}0.018 \\
(0.002)\end{array}$ & 0.346 \\
\hline 18-24 years old share of electorate & $\begin{array}{c}0.170 \\
(0.003)\end{array}$ & $\begin{array}{c}0.180 \\
(0.009)\end{array}$ & 0.236 \\
\hline 25-34 years old share of electorate & $\begin{array}{c}0.231 \\
(0.002)\end{array}$ & $\begin{array}{c}0.234 \\
(0.007)\end{array}$ & 0.664 \\
\hline $35-44$ years old share of electorate & $\begin{array}{c}0.191 \\
(0.002)\end{array}$ & $\begin{array}{c}0.187 \\
(0.004)\end{array}$ & 0.415 \\
\hline $45-59$ years old share of electorate & $\begin{array}{c}0.225 \\
(0.002)\end{array}$ & $\begin{array}{c}0.217 \\
(0.005)\end{array}$ & 0.182 \\
\hline $60-69$ years old share of electorate & $\begin{array}{c}0.091 \\
(0.001)\end{array}$ & $\begin{array}{c}0.090 \\
(0.003)\end{array}$ & 0.813 \\
\hline \multirow[b]{3}{*}{ Complete elementary school share of electorate } & $\begin{array}{c}0.075 \\
(0.002)\end{array}$ & $\begin{array}{c}0.072 \\
(0.005)\end{array}$ & 0.522 \\
\hline & $\begin{array}{c}0.489 \\
(0.004)\end{array}$ & $\begin{array}{c}0.500 \\
(0.010)\end{array}$ & 0.375 \\
\hline & $\begin{array}{c}0.239 \\
(0.002)\end{array}$ & $\begin{array}{c}0.240 \\
(0.006)\end{array}$ & 0.848 \\
\hline Complete high school share of electorate & $\begin{array}{c}0.161 \\
(0.003)\end{array}$ & $\begin{array}{c}0.155 \\
(0.008)\end{array}$ & 0.479 \\
\hline Married share of electorate & $\begin{array}{c}0.305 \\
(0.003)\end{array}$ & $\begin{array}{c}0.322 \\
(0.009)\end{array}$ & 0.043 \\
\hline Divorced share of electorate & $\begin{array}{c}0.024 \\
(0.001)\end{array}$ & $\begin{array}{c}0.023 \\
(0.001)\end{array}$ & 0.733 \\
\hline Single share of electorate & $\begin{array}{c}0.653 \\
(0.003)\end{array}$ & $\begin{array}{c}0.636 \\
(0.010)\end{array}$ & 0.081 \\
\hline $\mathrm{N}$ & 1222 & 145 & \\
\hline
\end{tabular}

Table C1: Polling stations characteristics: balance test. Control group: no signal within $10 \mathrm{~km}$

Notes: This table compares characteristics of polling stations that get any sponsored signal (treated) to those of ones that get no signal (control), conditional on treated and control being up to 10 kilometers apart from each other. For each treated, there may be more than one associated control. The last column report the p-value of the mean difference t-test. The variables are past PT vote share (2010, rounds 1 and 2), polling station distance from closest sponsored AM radio station's antenna, total electorate and polling station's electorate shares of male, 16-17, 18-24,25-34, 35-44, 45-59 and 60-69 years old, illiterate, incomplete elementary school, complete elementary school (or incomplete high school) and complete high school (or incomplete college), married, divorced and single. 


\begin{tabular}{|c|c|c|c|}
\hline \multicolumn{4}{|c|}{ Within $15 \mathrm{~km}$} \\
\hline & No-signal & Sponsored & diff.p-value \\
\hline \multirow[b]{3}{*}{ Distance to closest sponsored AM station } & $\begin{array}{c}0.517 \\
(0.004)\end{array}$ & $\begin{array}{c}0.519 \\
(0.011)\end{array}$ & 0.857 \\
\hline & $\begin{array}{c}0.576 \\
(0.004)\end{array}$ & $\begin{array}{c}0.573 \\
(0.011)\end{array}$ & 0.800 \\
\hline & $\begin{array}{l}17.553 \\
(0.388)\end{array}$ & $\begin{array}{l}18.513 \\
(1.171)\end{array}$ & 0.419 \\
\hline Total electorate & $\begin{array}{c}1655.416 \\
(27.909)\end{array}$ & $\begin{array}{c}1603.758 \\
(76.568)\end{array}$ & 0.541 \\
\hline Male share of electorate & $\begin{array}{c}0.488 \\
(0.001)\end{array}$ & $\begin{array}{c}0.492 \\
(0.003)\end{array}$ & 0.190 \\
\hline 16-17 years old share of electorate & $\begin{array}{c}0.016 \\
(0.000)\end{array}$ & $\begin{array}{c}0.015 \\
(0.001)\end{array}$ & 0.795 \\
\hline 18-24 years old share of electorate & $\begin{array}{c}0.166 \\
(0.002)\end{array}$ & $\begin{array}{c}0.169 \\
(0.006)\end{array}$ & 0.593 \\
\hline 25-34 years old share of electorate & $\begin{array}{c}0.229 \\
(0.002)\end{array}$ & $\begin{array}{c}0.227 \\
(0.004)\end{array}$ & 0.774 \\
\hline $35-44$ years old share of electorate & $\begin{array}{c}0.190 \\
(0.001)\end{array}$ & $\begin{array}{c}0.188 \\
(0.003)\end{array}$ & 0.499 \\
\hline $45-59$ years old share of electorate & $\begin{array}{c}0.228 \\
(0.001)\end{array}$ & $\begin{array}{c}0.228 \\
(0.004)\end{array}$ & 0.874 \\
\hline $60-69$ years old share of electorate & $\begin{array}{c}0.095 \\
(0.001)\end{array}$ & $\begin{array}{c}0.095 \\
(0.002)\end{array}$ & 0.914 \\
\hline \multirow[b]{3}{*}{ Complete elementary school share of electorate } & $\begin{array}{c}0.079 \\
(0.001)\end{array}$ & $\begin{array}{c}0.073 \\
(0.003)\end{array}$ & 0.155 \\
\hline & $\begin{array}{c}0.503 \\
(0.003)\end{array}$ & $\begin{array}{c}0.509 \\
(0.007)\end{array}$ & 0.501 \\
\hline & $\begin{array}{c}0.233 \\
(0.002)\end{array}$ & $\begin{array}{c}0.241 \\
(0.005)\end{array}$ & 0.090 \\
\hline Complete high school share of electorate & $\begin{array}{c}0.152 \\
(0.002)\end{array}$ & $\begin{array}{c}0.147 \\
(0.006)\end{array}$ & 0.396 \\
\hline Married share of electorate & $\begin{array}{c}0.317 \\
(0.002)\end{array}$ & $\begin{array}{c}0.335 \\
(0.006)\end{array}$ & 0.005 \\
\hline Divorced share of electorate & $\begin{array}{c}0.024 \\
(0.000)\end{array}$ & $\begin{array}{c}0.023 \\
(0.001)\end{array}$ & 0.761 \\
\hline Single share of electorate & $\begin{array}{c}0.641 \\
(0.002)\end{array}$ & $\begin{array}{c}0.623 \\
(0.007)\end{array}$ & 0.018 \\
\hline $\mathrm{N}$ & 2318 & 281 & \\
\hline
\end{tabular}

Table C2: Polling stations characteristics: balance test. Control group: no signal within $15 \mathrm{~km}$

Notes: This table compares characteristics of polling stations that get any sponsored signal (treated) to those of ones that get no signal (control), conditional on treated and control being up to 15 kilometers apart from each other. For each treated, there may be more than one associated control. The last column report the p-value of the mean difference t-test. The variables are past PT vote share (2010, rounds 1 and 2), polling station distance from closest sponsored AM radio station's antenna, total electorate and polling station's electorate shares of male, 16-17, 18-24,25-34, 35-44, 45-59 and 60-69 years old, illiterate, incomplete elementary school, complete elementary school (or incomplete high school) and complete high school (or incomplete college), married, divorced and single. 


\begin{tabular}{|c|c|c|c|}
\hline \multicolumn{4}{|c|}{ Within $20 \mathrm{~km}$} \\
\hline & No-signal & Sponsored & diff.p-value \\
\hline \multirow[b]{3}{*}{ Distance to closest sponsored AM station } & $\begin{array}{c}0.522 \\
(0.003)\end{array}$ & $\begin{array}{c}0.503 \\
(0.009)\end{array}$ & 0.055 \\
\hline & $\begin{array}{c}0.580 \\
(0.003)\end{array}$ & $\begin{array}{c}0.556 \\
(0.009)\end{array}$ & 0.014 \\
\hline & $\begin{array}{c}18.632 \\
(0.242)\end{array}$ & $\begin{array}{l}17.252 \\
(0.827)\end{array}$ & 0.084 \\
\hline Total electorate & $\begin{array}{c}1604.494 \\
(19.491)\end{array}$ & $\begin{array}{l}1620.107 \\
(61.789)\end{array}$ & 0.807 \\
\hline Male share of electorate & $\begin{array}{c}0.490 \\
(0.001)\end{array}$ & $\begin{array}{c}0.493 \\
(0.002)\end{array}$ & 0.176 \\
\hline 16-17 years old share of electorate & $\begin{array}{c}0.016 \\
(0.000)\end{array}$ & $\begin{array}{c}0.015 \\
(0.001)\end{array}$ & 0.373 \\
\hline $18-24$ years old share of electorate & $\begin{array}{c}0.163 \\
(0.001)\end{array}$ & $\begin{array}{c}0.175 \\
(0.005)\end{array}$ & 0.004 \\
\hline 25-34 years old share of electorate & $\begin{array}{c}0.227 \\
(0.001)\end{array}$ & $\begin{array}{c}0.228 \\
(0.003)\end{array}$ & 0.902 \\
\hline $35-44$ years old share of electorate & $\begin{array}{c}0.190 \\
(0.001)\end{array}$ & $\begin{array}{c}0.189 \\
(0.002)\end{array}$ & 0.549 \\
\hline $45-59$ years old share of electorate & $\begin{array}{c}0.228 \\
(0.001)\end{array}$ & $\begin{array}{c}0.225 \\
(0.003)\end{array}$ & 0.368 \\
\hline $60-69$ years old share of electorate & $\begin{array}{c}0.096 \\
(0.001)\end{array}$ & $\begin{array}{c}0.094 \\
(0.002)\end{array}$ & 0.169 \\
\hline \multirow[b]{3}{*}{ Complete elementary school share of electorate } & $\begin{array}{c}0.080 \\
(0.001)\end{array}$ & $\begin{array}{c}0.068 \\
(0.003)\end{array}$ & 0.000 \\
\hline & $\begin{array}{c}0.514 \\
(0.002)\end{array}$ & $\begin{array}{c}0.506 \\
(0.006)\end{array}$ & 0.158 \\
\hline & $\begin{array}{c}0.231 \\
(0.001)\end{array}$ & $\begin{array}{c}0.247 \\
(0.004)\end{array}$ & 0.000 \\
\hline Complete high school share of electorate & $\begin{array}{c}0.144 \\
(0.001)\end{array}$ & $\begin{array}{c}0.151 \\
(0.004)\end{array}$ & 0.163 \\
\hline Married share of electorate & $\begin{array}{c}0.320 \\
(0.002)\end{array}$ & $\begin{array}{c}0.336 \\
(0.005)\end{array}$ & 0.002 \\
\hline Divorced share of electorate & $\begin{array}{c}0.022 \\
(0.000)\end{array}$ & $\begin{array}{c}0.024 \\
(0.001)\end{array}$ & 0.026 \\
\hline Single share of electorate & $\begin{array}{c}0.639 \\
(0.002)\end{array}$ & $\begin{array}{c}0.621 \\
(0.006)\end{array}$ & 0.001 \\
\hline 14 & 4547 & 468 & \\
\hline
\end{tabular}

Table C3: Polling stations characteristics: balance test. Control group: no signal within $20 \mathrm{~km}$

Notes: This table compares characteristics of polling stations that get any sponsored signal (treated) to those of ones that get no signal (control), conditional on treated and control being up to 20 kilometers apart from each other. For each treated, there may be more than one associated control. The last column report the p-value of the mean difference t-test. The variables are past PT vote share (2010, rounds 1 and 2), polling station distance from closest sponsored AM radio station's antenna, total electorate and polling station's electorate shares of male, 16-17, 18-24,25-34, 35-44, 45-59 and 60-69 years old, illiterate, incomplete elementary school, complete elementary school (or incomplete high school) and complete high school (or incomplete college), married, divorced and single. 


\begin{tabular}{|c|c|c|c|}
\hline \multicolumn{4}{|c|}{ Within $25 \mathrm{~km}$} \\
\hline & No-signal & Sponsored & diff.p-value \\
\hline \multirow[b]{3}{*}{ Distance to closest sponsored AM station } & $\begin{array}{c}0.533 \\
(0.002)\end{array}$ & $\begin{array}{c}0.500 \\
(0.008)\end{array}$ & 0.000 \\
\hline & $\begin{array}{c}0.587 \\
(0.002)\end{array}$ & $\begin{array}{c}0.553 \\
(0.008)\end{array}$ & 0.000 \\
\hline & $\begin{array}{l}19.706 \\
(0.178)\end{array}$ & $\begin{array}{l}17.004 \\
(0.715)\end{array}$ & 0.000 \\
\hline Total electorate & $\begin{array}{c}1538.308 \\
(14.521)\end{array}$ & $\begin{array}{c}1633.035 \\
(52.466)\end{array}$ & 0.076 \\
\hline Male share of electorate & $\begin{array}{c}0.492 \\
(0.000)\end{array}$ & $\begin{array}{c}0.492 \\
(0.002)\end{array}$ & 0.910 \\
\hline 16-17 years old share of electorate & $\begin{array}{c}0.016 \\
(0.000)\end{array}$ & $\begin{array}{c}0.016 \\
(0.001)\end{array}$ & 0.614 \\
\hline $18-24$ years old share of electorate & $\begin{array}{c}0.160 \\
(0.001)\end{array}$ & $\begin{array}{c}0.176 \\
(0.004)\end{array}$ & 0.000 \\
\hline 25-34 years old share of electorate & $\begin{array}{c}0.226 \\
(0.001)\end{array}$ & $\begin{array}{c}0.230 \\
(0.003)\end{array}$ & 0.201 \\
\hline $35-44$ years old share of electorate & $\begin{array}{c}0.190 \\
(0.001)\end{array}$ & $\begin{array}{c}0.189 \\
(0.002)\end{array}$ & 0.550 \\
\hline 45-59 years old share of electorate & $\begin{array}{c}0.229 \\
(0.001)\end{array}$ & $\begin{array}{c}0.225 \\
(0.002)\end{array}$ & 0.106 \\
\hline $60-69$ years old share of electorate & $\begin{array}{c}0.098 \\
(0.000)\end{array}$ & $\begin{array}{c}0.093 \\
(0.001)\end{array}$ & 0.001 \\
\hline \multirow[b]{3}{*}{ Complete elementary school share of electorate } & $\begin{array}{c}0.082 \\
(0.001)\end{array}$ & $\begin{array}{c}0.067 \\
(0.002)\end{array}$ & 0.000 \\
\hline & $\begin{array}{c}0.527 \\
(0.001)\end{array}$ & $\begin{array}{c}0.502 \\
(0.005)\end{array}$ & 0.000 \\
\hline & $\begin{array}{c}0.230 \\
(0.001)\end{array}$ & $\begin{array}{c}0.250 \\
(0.003)\end{array}$ & 0.000 \\
\hline Complete high school share of electorate & $\begin{array}{c}0.134 \\
(0.001)\end{array}$ & $\begin{array}{c}0.152 \\
(0.004)\end{array}$ & 0.000 \\
\hline Married share of electorate & $\begin{array}{c}0.323 \\
(0.001)\end{array}$ & $\begin{array}{c}0.329 \\
(0.004)\end{array}$ & 0.180 \\
\hline Divorced share of electorate & $\begin{array}{c}0.021 \\
(0.000)\end{array}$ & $\begin{array}{c}0.025 \\
(0.001)\end{array}$ & 0.000 \\
\hline Single share of electorate & $\begin{array}{c}0.638 \\
(0.001)\end{array}$ & $\begin{array}{c}0.628 \\
(0.005)\end{array}$ & 0.050 \\
\hline $\mathrm{N}$ & 7833 & 630 & \\
\hline
\end{tabular}

Table C4: Polling stations characteristics: balance test. Control group: no signal within $25 \mathrm{~km}$

Notes: This table compares characteristics of polling stations that get any sponsored signal (treated) to those of ones that get no signal (control), conditional on treated and control being up to 25 kilometers apart from each other. For each treated, there may be more than one associated control. The last column report the p-value of the mean difference t-test. The variables are past PT vote share (2010, rounds 1 and 2), polling station distance from closest sponsored AM radio station's antenna, total electorate and polling station's electorate shares of male, 16-17, 18-24,25-34, 35-44, 45-59 and 60-69 years old, illiterate, incomplete elementary school, complete elementary school (or incomplete high school) and complete high school (or incomplete college), married, divorced and single. 


\begin{tabular}{|c|c|c|c|}
\hline \multicolumn{4}{|c|}{ Within $30 \mathrm{~km}$} \\
\hline & No-signal & Sponsored & diff.p-value \\
\hline \multirow[b]{3}{*}{ Distance to closest sponsored AM station } & $\begin{array}{c}0.534 \\
(0.002)\end{array}$ & $\begin{array}{c}0.491 \\
(0.007)\end{array}$ & 0.000 \\
\hline & $\begin{array}{c}0.586 \\
(0.002)\end{array}$ & $\begin{array}{c}0.546 \\
(0.007)\end{array}$ & 0.000 \\
\hline & $\begin{array}{l}20.076 \\
(0.136)\end{array}$ & $\begin{array}{l}16.232 \\
(0.610)\end{array}$ & 0.000 \\
\hline Total electorate & $\begin{array}{c}1552.611 \\
(11.493)\end{array}$ & $\begin{array}{l}1629.599 \\
(46.648)\end{array}$ & 0.104 \\
\hline Male share of electorate & $\begin{array}{c}0.493 \\
(0.000)\end{array}$ & $\begin{array}{c}0.493 \\
(0.002)\end{array}$ & 0.880 \\
\hline 16-17 years old share of electorate & $\begin{array}{c}0.016 \\
(0.000)\end{array}$ & $\begin{array}{c}0.015 \\
(0.001)\end{array}$ & 0.572 \\
\hline 18-24 years old share of electorate & $\begin{array}{c}0.160 \\
(0.001)\end{array}$ & $\begin{array}{c}0.179 \\
(0.004)\end{array}$ & 0.000 \\
\hline 25-34 years old share of electorate & $\begin{array}{c}0.226 \\
(0.001)\end{array}$ & $\begin{array}{c}0.228 \\
(0.003)\end{array}$ & 0.418 \\
\hline $35-44$ years old share of electorate & $\begin{array}{c}0.190 \\
(0.000)\end{array}$ & $\begin{array}{c}0.189 \\
(0.002)\end{array}$ & 0.487 \\
\hline 45-59 years old share of electorate & $\begin{array}{c}0.229 \\
(0.001)\end{array}$ & $\begin{array}{c}0.224 \\
(0.002)\end{array}$ & 0.031 \\
\hline $60-69$ years old share of electorate & $\begin{array}{c}0.098 \\
(0.000)\end{array}$ & $\begin{array}{c}0.092 \\
(0.001)\end{array}$ & 0.000 \\
\hline \multirow[b]{3}{*}{ Complete elementary school share of electorate } & $\begin{array}{c}0.082 \\
(0.001)\end{array}$ & $\begin{array}{c}0.066 \\
(0.002)\end{array}$ & 0.000 \\
\hline & $\begin{array}{c}0.527 \\
(0.001)\end{array}$ & $\begin{array}{c}0.494 \\
(0.005)\end{array}$ & 0.000 \\
\hline & $\begin{array}{c}0.230 \\
(0.001)\end{array}$ & $\begin{array}{c}0.254 \\
(0.003)\end{array}$ & 0.000 \\
\hline Complete high school share of electorate & $\begin{array}{c}0.133 \\
(0.001)\end{array}$ & $\begin{array}{c}0.156 \\
(0.003)\end{array}$ & 0.000 \\
\hline Married share of electorate & $\begin{array}{c}0.323 \\
(0.001)\end{array}$ & $\begin{array}{c}0.326 \\
(0.004)\end{array}$ & 0.583 \\
\hline Divorced share of electorate & $\begin{array}{c}0.022 \\
(0.000)\end{array}$ & $\begin{array}{c}0.025 \\
(0.001)\end{array}$ & 0.000 \\
\hline Single share of electorate & $\begin{array}{c}0.637 \\
(0.001)\end{array}$ & $\begin{array}{c}0.631 \\
(0.004)\end{array}$ & 0.183 \\
\hline $\mathrm{N}$ & 12655 & 793 & \\
\hline
\end{tabular}

Table C5: Polling stations characteristics: balance test. Control group: no signal within $30 \mathrm{~km}$

Notes: This table compares characteristics of polling stations that get any sponsored signal (treated) to those of ones that get no signal (control), conditional on treated and control being up to 30 kilometers apart from each other. For each treated, there may be more than one associated control. The last column report the p-value of the mean difference t-test. The variables are past PT vote share (2010, rounds 1 and 2), polling station distance from closest sponsored AM radio station's antenna, total electorate and polling station's electorate shares of male, 16-17, 18-24,25-34, 35-44, 45-59 and 60-69 years old, illiterate, incomplete elementary school, complete elementary school (or incomplete high school) and complete high school (or incomplete college), married, divorced and single. 


\begin{tabular}{|c|c|c|c|}
\hline \multicolumn{4}{|c|}{ Within $40 \mathrm{~km}$} \\
\hline & No-signal & Sponsored & diff.p-value \\
\hline \multirow[b]{3}{*}{ Distance to closest sponsored AM station } & $\begin{array}{c}0.537 \\
(0.001)\end{array}$ & $\begin{array}{c}0.478 \\
(0.006)\end{array}$ & 0.000 \\
\hline & $\begin{array}{c}0.588 \\
(0.001)\end{array}$ & $\begin{array}{c}0.537 \\
(0.006)\end{array}$ & 0.000 \\
\hline & $\begin{array}{l}21.294 \\
(0.096)\end{array}$ & $\begin{array}{l}15.084 \\
(0.525)\end{array}$ & 0.000 \\
\hline Total electorate & $\begin{array}{c}1532.887 \\
(8.027)\end{array}$ & $\begin{array}{l}1698.695 \\
(42.948)\end{array}$ & 0.000 \\
\hline Male share of electorate & $\begin{array}{c}0.494 \\
(0.000)\end{array}$ & $\begin{array}{c}0.492 \\
(0.002)\end{array}$ & 0.201 \\
\hline 16-17 years old share of electorate & $\begin{array}{c}0.016 \\
(0.000)\end{array}$ & $\begin{array}{c}0.015 \\
(0.001)\end{array}$ & 0.049 \\
\hline 18-24 years old share of electorate & $\begin{array}{c}0.160 \\
(0.001)\end{array}$ & $\begin{array}{c}0.177 \\
(0.003)\end{array}$ & 0.000 \\
\hline 25-34 years old share of electorate & $\begin{array}{c}0.226 \\
(0.000)\end{array}$ & $\begin{array}{c}0.228 \\
(0.002)\end{array}$ & 0.318 \\
\hline $35-44$ years old share of electorate & $\begin{array}{c}0.190 \\
(0.000)\end{array}$ & $\begin{array}{c}0.192 \\
(0.002)\end{array}$ & 0.385 \\
\hline 45-59 years old share of electorate & $\begin{array}{c}0.228 \\
(0.000)\end{array}$ & $\begin{array}{c}0.226 \\
(0.002)\end{array}$ & 0.151 \\
\hline $60-69$ years old share of electorate & $\begin{array}{c}0.098 \\
(0.000)\end{array}$ & $\begin{array}{c}0.092 \\
(0.001)\end{array}$ & 0.000 \\
\hline \multirow[b]{3}{*}{ Complete elementary school share of electorate } & $\begin{array}{c}0.085 \\
(0.000)\end{array}$ & $\begin{array}{c}0.062 \\
(0.002)\end{array}$ & 0.000 \\
\hline & $\begin{array}{c}0.531 \\
(0.001)\end{array}$ & $\begin{array}{c}0.488 \\
(0.004)\end{array}$ & 0.000 \\
\hline & $\begin{array}{c}0.228 \\
(0.000)\end{array}$ & $\begin{array}{c}0.257 \\
(0.003)\end{array}$ & 0.000 \\
\hline Complete high school share of electorate & $\begin{array}{c}0.129 \\
(0.001)\end{array}$ & $\begin{array}{c}0.161 \\
(0.003)\end{array}$ & 0.000 \\
\hline Married share of electorate & $\begin{array}{c}0.322 \\
(0.001)\end{array}$ & $\begin{array}{c}0.328 \\
(0.003)\end{array}$ & 0.102 \\
\hline Divorced share of electorate & $\begin{array}{c}0.021 \\
(0.000)\end{array}$ & $\begin{array}{c}0.027 \\
(0.001)\end{array}$ & 0.000 \\
\hline Single share of electorate & $\begin{array}{c}0.639 \\
(0.001)\end{array}$ & $\begin{array}{c}0.627 \\
(0.004)\end{array}$ & 0.002 \\
\hline $\mathrm{N}$ & 26265 & 1061 & \\
\hline
\end{tabular}

Table C6: Polling stations characteristics: balance test. Control group: no signal within $40 \mathrm{~km}$

Notes: This table compares characteristics of polling stations that get any sponsored signal (treated) to those of ones that get no signal (control), conditional on treated and control being up to 40 kilometers apart from each other. For each treated, there may be more than one associated control. The last column report the p-value of the mean difference t-test. The variables are past PT vote share (2010, rounds 1 and 2), polling station distance from closest sponsored AM radio station's antenna, total electorate and polling station's electorate shares of male, 16-17, 18-24,25-34, 35-44, 45-59 and 60-69 years old, illiterate, incomplete elementary school, complete elementary school (or incomplete high school) and complete high school (or incomplete college), married, divorced and single. 


\begin{tabular}{|c|c|c|c|}
\hline \multicolumn{4}{|c|}{ Within $50 \mathrm{~km}$} \\
\hline & No-signal & Sponsored & diff.p-value \\
\hline \multirow[b]{3}{*}{ Distance to closest sponsored AM station } & $\begin{array}{c}0.541 \\
(0.001)\end{array}$ & $\begin{array}{c}0.473 \\
(0.006)\end{array}$ & 0.000 \\
\hline & $\begin{array}{c}0.591 \\
(0.001)\end{array}$ & $\begin{array}{c}0.532 \\
(0.006)\end{array}$ & 0.000 \\
\hline & $\begin{array}{l}22.112 \\
(0.074)\end{array}$ & $\begin{array}{l}14.931 \\
(0.521)\end{array}$ & 0.000 \\
\hline Total electorate & $\begin{array}{c}1513.365 \\
(6.095)\end{array}$ & $\begin{array}{l}1742.648 \\
(41.256)\end{array}$ & 0.000 \\
\hline Male share of electorate & $\begin{array}{c}0.495 \\
(0.000)\end{array}$ & $\begin{array}{c}0.492 \\
(0.002)\end{array}$ & 0.019 \\
\hline 16-17 years old share of electorate & $\begin{array}{c}0.016 \\
(0.000)\end{array}$ & $\begin{array}{c}0.015 \\
(0.001)\end{array}$ & 0.042 \\
\hline 18-24 years old share of electorate & $\begin{array}{c}0.160 \\
(0.000)\end{array}$ & $\begin{array}{c}0.177 \\
(0.003)\end{array}$ & 0.000 \\
\hline 25-34 years old share of electorate & $\begin{array}{c}0.225 \\
(0.000)\end{array}$ & $\begin{array}{c}0.230 \\
(0.002)\end{array}$ & 0.018 \\
\hline $35-44$ years old share of electorate & $\begin{array}{c}0.190 \\
(0.000)\end{array}$ & $\begin{array}{c}0.191 \\
(0.002)\end{array}$ & 0.557 \\
\hline $45-59$ years old share of electorate & $\begin{array}{c}0.228 \\
(0.000)\end{array}$ & $\begin{array}{c}0.226 \\
(0.002)\end{array}$ & 0.108 \\
\hline $60-69$ years old share of electorate & $\begin{array}{c}0.098 \\
(0.000)\end{array}$ & $\begin{array}{c}0.091 \\
(0.001)\end{array}$ & 0.000 \\
\hline \multirow[b]{3}{*}{ Complete elementary school share of electorate } & $\begin{array}{c}0.086 \\
(0.000)\end{array}$ & $\begin{array}{c}0.060 \\
(0.002)\end{array}$ & 0.000 \\
\hline & $\begin{array}{c}0.533 \\
(0.001)\end{array}$ & $\begin{array}{c}0.483 \\
(0.004)\end{array}$ & 0.000 \\
\hline & $\begin{array}{c}0.228 \\
(0.000)\end{array}$ & $\begin{array}{c}0.258 \\
(0.002)\end{array}$ & 0.000 \\
\hline Complete high school share of electorate & $\begin{array}{c}0.127 \\
(0.000)\end{array}$ & $\begin{array}{c}0.166 \\
(0.003)\end{array}$ & 0.000 \\
\hline Married share of electorate & $\begin{array}{c}0.321 \\
(0.001)\end{array}$ & $\begin{array}{c}0.327 \\
(0.003)\end{array}$ & 0.062 \\
\hline Divorced share of electorate & $\begin{array}{c}0.021 \\
(0.000)\end{array}$ & $\begin{array}{c}0.028 \\
(0.001)\end{array}$ & 0.000 \\
\hline Single share of electorate & $\begin{array}{c}0.639 \\
(0.001)\end{array}$ & $\begin{array}{c}0.626 \\
(0.003)\end{array}$ & 0.000 \\
\hline $\mathrm{N}$ & 44411 & 1192 & \\
\hline
\end{tabular}

Table C7: Polling stations characteristics: balance test. Control group: no signal within $50 \mathrm{~km}$

Notes: This table compares characteristics of polling stations that get any sponsored signal (treated) to those of ones that get no signal (control), conditional on treated and control being up to 50 kilometers apart from each other. For each treated, there may be more than one associated control. The last column report the p-value of the mean difference t-test. The variables are past PT vote share (2010, rounds 1 and 2), polling station distance from closest sponsored AM radio station's antenna, total electorate and polling station's electorate shares of male, 16-17, 18-24,25-34, 35-44, 45-59 and 60-69 years old, illiterate, incomplete elementary school, complete elementary school (or incomplete high school) and complete high school (or incomplete college), married, divorced and single. 


\begin{tabular}{|c|c|c|c|}
\hline \multicolumn{4}{|c|}{ Within $5 \mathrm{~km}$} \\
\hline & Non-sponsored & Sponsored & diff. p-value \\
\hline \multirow[b]{4}{*}{ Distance to closest sponsored AM station } & 0.595 & 0.476 & 0.052 \\
\hline & $(0.016)$ & $(0.052)$ & \\
\hline & $\begin{array}{c}0.662 \\
(0.016)\end{array}$ & $\begin{array}{c}0.572 \\
(0.050)\end{array}$ & 0.137 \\
\hline & $\begin{array}{l}11.368 \\
(1.282)\end{array}$ & $\begin{array}{l}20.601 \\
(5.626)\end{array}$ & 0.066 \\
\hline Total electorate & $\begin{array}{c}1478.876 \\
(77.693)\end{array}$ & $\begin{array}{l}2164.882 \\
(451.384)\end{array}$ & 0.029 \\
\hline Male share of electorate & $\begin{array}{c}0.484 \\
(0.004)\end{array}$ & $\begin{array}{c}0.466 \\
(0.008)\end{array}$ & 0.245 \\
\hline 16-17 years old share of electorate & $\begin{array}{c}0.017 \\
(0.001)\end{array}$ & $\begin{array}{c}0.019 \\
(0.004)\end{array}$ & 0.700 \\
\hline 18-24 years old share of electorate & $\begin{array}{c}0.173 \\
(0.005)\end{array}$ & $\begin{array}{c}0.218 \\
(0.031)\end{array}$ & 0.032 \\
\hline 25-34 years old share of electorate & $\begin{array}{c}0.244 \\
(0.006)\end{array}$ & $\begin{array}{l}0.226 \\
(0.016)\end{array}$ & 0.472 \\
\hline $35-44$ years old share of electorate & $\begin{array}{c}0.199 \\
(0.004)\end{array}$ & $\begin{array}{c}0.199 \\
(0.009)\end{array}$ & 0.963 \\
\hline 45-59 years old share of electorate & $\begin{array}{c}0.221 \\
(0.004)\end{array}$ & $\begin{array}{c}0.205 \\
(0.011)\end{array}$ & 0.269 \\
\hline $60-69$ years old share of electorate & $\begin{array}{c}0.085 \\
(0.002)\end{array}$ & $\begin{array}{c}0.084 \\
(0.007)\end{array}$ & 0.854 \\
\hline Illiterate share of electorate & $\begin{array}{c}0.091 \\
(0.005)\end{array}$ & $\begin{array}{c}0.064 \\
(0.016)\end{array}$ & 0.166 \\
\hline Incomplete elementary school share of electorate & $\begin{array}{c}0.435 \\
(0.010)\end{array}$ & $\begin{array}{c}0.367 \\
(0.037)\end{array}$ & 0.078 \\
\hline Complete elementary school share of electorate & $\begin{array}{c}0.206 \\
(0.005)\end{array}$ & $\begin{array}{c}0.230 \\
(0.021)\end{array}$ & 0.197 \\
\hline Complete high school share of electorate & $\begin{array}{c}0.205 \\
(0.009)\end{array}$ & $\begin{array}{c}0.262 \\
(0.032)\end{array}$ & 0.090 \\
\hline Married share of electorate & $\begin{array}{c}0.335 \\
(0.006)\end{array}$ & $\begin{array}{c}0.324 \\
(0.014)\end{array}$ & 0.598 \\
\hline Divorced share of electorate & $\begin{array}{c}0.027 \\
(0.002)\end{array}$ & $\begin{array}{c}0.037 \\
(0.006)\end{array}$ & 0.141 \\
\hline Single share of electorate & $\begin{array}{c}0.618 \\
(0.007)\end{array}$ & $\begin{array}{c}0.616 \\
(0.020)\end{array}$ & 0.939 \\
\hline $\mathrm{N}$ & 235 & 17 & \\
\hline
\end{tabular}

Table C8: Polling stations characteristics: balance test. Control group: nonsponsored signal within $5 \mathrm{~km}$

Notes: This table compares characteristics of polling stations that get any sponsored signal (treated) to those of ones that get non-sponsored signal (control), conditional on treated and control being up to 5 kilometers apart from each other. For each treated, there may be more than one associated control. The last column report the p-value of the mean difference t-test. The variables are past PT vote share (2010, rounds 1 and 2), polling station distance from closest sponsored AM radio station's antenna, total electorate and polling station's electorate shares of male, 16-17, 18-24,25-34, 35-44, 45-59 and 60-69 years old, illiterate, incomplete elementary school, complete elementary school (or incomplete high school) and complete high school (or incomplete college), married, divorced and single. 


\begin{tabular}{|c|c|c|c|}
\hline \multicolumn{4}{|c|}{ Within $10 \mathrm{~km}$} \\
\hline & Non-sponsored & Sponsored & diff. p-value \\
\hline \multirow[b]{3}{*}{ Distance to closest sponsored AM station } & $\begin{array}{c}0.543 \\
(0.012)\end{array}$ & $\begin{array}{c}0.474 \\
(0.032)\end{array}$ & 0.085 \\
\hline & $\begin{array}{c}0.612 \\
(0.012)\end{array}$ & $\begin{array}{c}0.537 \\
(0.032)\end{array}$ & 0.062 \\
\hline & $\begin{array}{l}12.439 \\
(0.933)\end{array}$ & $\begin{array}{l}15.658 \\
(3.191)\end{array}$ & 0.306 \\
\hline Total electorate & $\begin{array}{c}1563.846 \\
(66.093)\end{array}$ & $\begin{array}{l}2048.353 \\
(280.500)\end{array}$ & 0.034 \\
\hline Male share of electorate & $\begin{array}{c}0.486 \\
(0.003)\end{array}$ & $\begin{array}{c}0.482 \\
(0.006)\end{array}$ & 0.637 \\
\hline $16-17$ years old share of electorate & $\begin{array}{c}0.016 \\
(0.001)\end{array}$ & $\begin{array}{c}0.016 \\
(0.002)\end{array}$ & 0.802 \\
\hline 18-24 years old share of electorate & $\begin{array}{c}0.168 \\
(0.005)\end{array}$ & $\begin{array}{c}0.195 \\
(0.019)\end{array}$ & 0.085 \\
\hline 25-34 years old share of electorate & $\begin{array}{c}0.236 \\
(0.005)\end{array}$ & $\begin{array}{c}0.216 \\
(0.010)\end{array}$ & 0.211 \\
\hline $35-44$ years old share of electorate & $\begin{array}{c}0.197 \\
(0.003)\end{array}$ & $\begin{array}{c}0.195 \\
(0.008)\end{array}$ & 0.836 \\
\hline $45-59$ years old share of electorate & $\begin{array}{c}0.228 \\
(0.003)\end{array}$ & $\begin{array}{c}0.220 \\
(0.008)\end{array}$ & 0.423 \\
\hline $60-69$ years old share of electorate & $\begin{array}{c}0.089 \\
(0.002)\end{array}$ & $\begin{array}{c}0.094 \\
(0.006)\end{array}$ & 0.465 \\
\hline Illiterate share of electorate & $\begin{array}{c}0.077 \\
(0.004)\end{array}$ & $\begin{array}{c}0.056 \\
(0.009)\end{array}$ & 0.098 \\
\hline Literate share of electorate & $\begin{array}{c}0.439 \\
(0.008)\end{array}$ & $\begin{array}{c}0.421 \\
(0.025)\end{array}$ & 0.496 \\
\hline Complete elementary school share of electorate & $\begin{array}{c}0.224 \\
(0.004)\end{array}$ & $\begin{array}{c}0.244 \\
(0.014)\end{array}$ & 0.138 \\
\hline Complete high school share of electorate & $\begin{array}{c}0.201 \\
(0.007)\end{array}$ & $\begin{array}{l}0.219 \\
(0.021)\end{array}$ & 0.410 \\
\hline Married share of electorate & $\begin{array}{c}0.340 \\
(0.005)\end{array}$ & $\begin{array}{c}0.343 \\
(0.013)\end{array}$ & 0.869 \\
\hline Divorced share of electorate & $\begin{array}{c}0.029 \\
(0.001)\end{array}$ & $\begin{array}{c}0.038 \\
(0.004)\end{array}$ & 0.055 \\
\hline Single share of electorate & $\begin{array}{c}0.610 \\
(0.006)\end{array}$ & $\begin{array}{c}0.594 \\
(0.017)\end{array}$ & 0.410 \\
\hline $\mathrm{N}$ & 346 & 34 & \\
\hline
\end{tabular}

Table C9: Polling stations characteristics: balance test. Control group: nonsponsored signal within $10 \mathrm{~km}$

Notes: This table compares characteristics of polling stations that get any sponsored signal (treated) to those of ones that get non-sponsored signal (control), conditional on treated and control being up to 10 kilometers apart from each other. For each treated, there may be more than one associated control. The last column report the p-value of the mean difference t-test. The variables are past PT vote share (2010, rounds 1 and 2), polling station distance from closest sponsored AM radio station's antenna, total electorate and polling station's electorate shares of male, 16-17, 18-24,25-34, 35-44, 45-59 and 60-69 years old, illiterate, incomplete elementary school, complete elementary school (or incomplete high school) and complete high school (or incomplete college), married, divorced and single. 


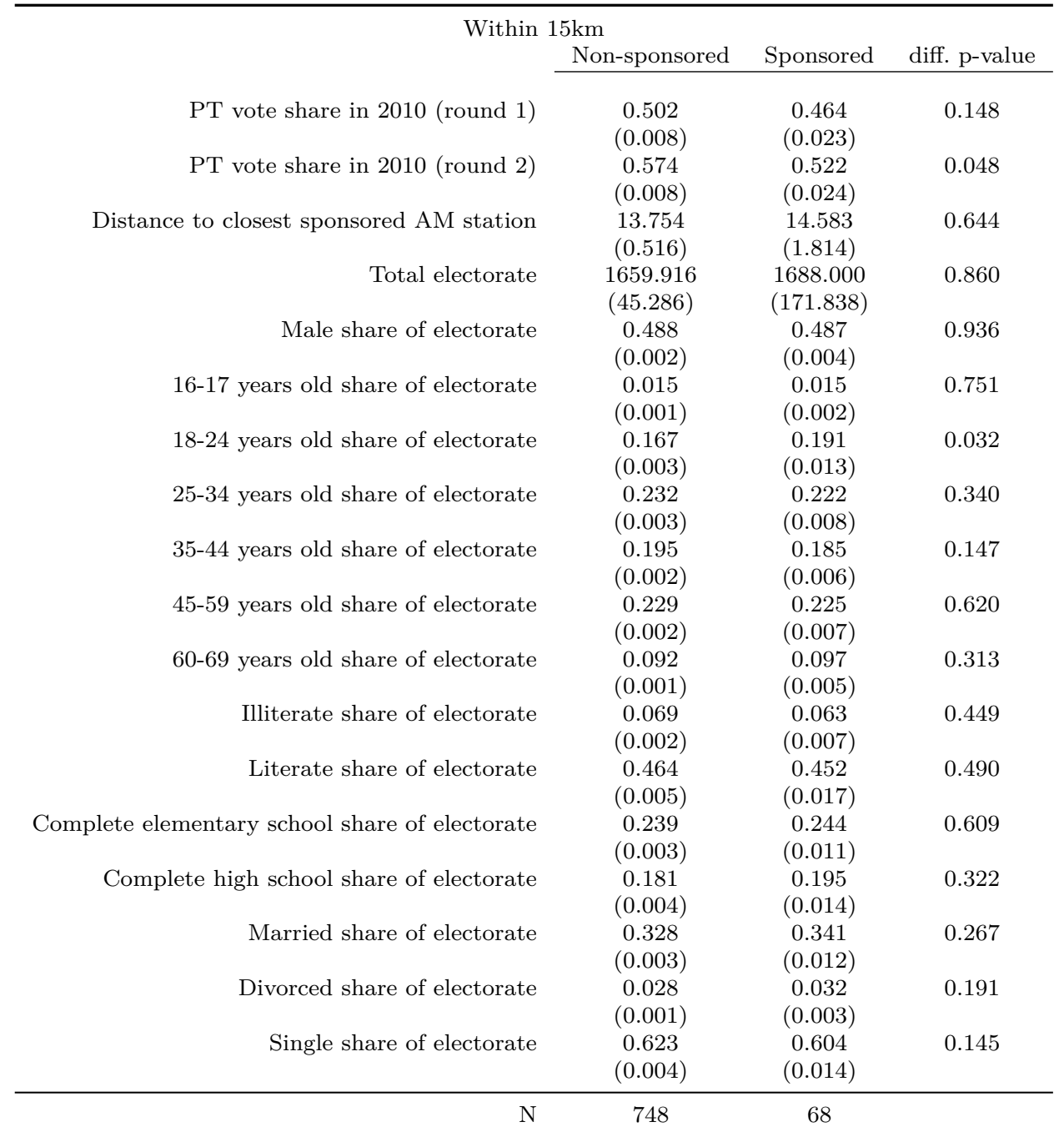

Table C10: Polling stations characteristics: balance test. Control group: nonsponsored signal within $15 \mathrm{~km}$

Notes: This table compares characteristics of polling stations that get any sponsored signal (treated) to those of ones that get non-sponsored signal (control), conditional on treated and control being up to 15 kilometers apart from each other. For each treated, there may be more than one associated control. The last column report the p-value of the mean difference t-test. The variables are past PT vote share (2010, rounds 1 and 2), polling station distance from closest sponsored AM radio station's antenna, total electorate and polling station's electorate shares of male, 16-17, 18-24,25-34, 35-44, 45-59 and 60-69 years old, illiterate, incomplete elementary school, complete elementary school (or incomplete high school) and complete high school (or incomplete college), married, divorced and single. 


\begin{tabular}{|c|c|c|c|}
\hline \multicolumn{4}{|c|}{ Within $20 \mathrm{~km}$} \\
\hline & Non-sponsored & Sponsored & diff. p-value \\
\hline \multirow[b]{3}{*}{ Distance to closest sponsored AM station } & $\begin{array}{c}0.504 \\
(0.005)\end{array}$ & $\begin{array}{c}0.464 \\
(0.019)\end{array}$ & 0.038 \\
\hline & $\begin{array}{c}0.569 \\
(0.005)\end{array}$ & $\begin{array}{c}0.521 \\
(0.020)\end{array}$ & 0.013 \\
\hline & $\begin{array}{l}14.711 \\
(0.313)\end{array}$ & $\begin{array}{l}13.891 \\
(1.198)\end{array}$ & 0.505 \\
\hline Total electorate & $\begin{array}{l}1564.592 \\
(31.455)\end{array}$ & $\begin{array}{l}1583.063 \\
(126.705)\end{array}$ & 0.881 \\
\hline Male share of electorate & $\begin{array}{c}0.489 \\
(0.001)\end{array}$ & $\begin{array}{c}0.486 \\
(0.003)\end{array}$ & 0.449 \\
\hline $16-17$ years old share of electorate & $\begin{array}{c}0.015 \\
(0.001)\end{array}$ & $\begin{array}{c}0.017 \\
(0.002)\end{array}$ & 0.316 \\
\hline 18-24 years old share of electorate & $\begin{array}{c}0.164 \\
(0.002)\end{array}$ & $\begin{array}{c}0.182 \\
(0.009)\end{array}$ & 0.038 \\
\hline 25-34 years old share of electorate & $\begin{array}{c}0.232 \\
(0.002)\end{array}$ & $\begin{array}{c}0.228 \\
(0.007)\end{array}$ & 0.662 \\
\hline $35-44$ years old share of electorate & $\begin{array}{c}0.191 \\
(0.001)\end{array}$ & $\begin{array}{c}0.187 \\
(0.005)\end{array}$ & 0.455 \\
\hline $45-59$ years old share of electorate & $\begin{array}{c}0.227 \\
(0.002)\end{array}$ & $\begin{array}{c}0.224 \\
(0.006)\end{array}$ & 0.589 \\
\hline $60-69$ years old share of electorate & $\begin{array}{c}0.094 \\
(0.001)\end{array}$ & $\begin{array}{c}0.094 \\
(0.004)\end{array}$ & 0.852 \\
\hline \multirow[b]{3}{*}{ Complete elementary school share of electorate } & $\begin{array}{c}0.071 \\
(0.002)\end{array}$ & $\begin{array}{c}0.060 \\
(0.005)\end{array}$ & 0.067 \\
\hline & $\begin{array}{c}0.484 \\
(0.003)\end{array}$ & $\begin{array}{c}0.458 \\
(0.013)\end{array}$ & 0.037 \\
\hline & $\begin{array}{c}0.244 \\
(0.002)\end{array}$ & $\begin{array}{c}0.257 \\
(0.008)\end{array}$ & 0.114 \\
\hline Complete high school share of electorate & $\begin{array}{c}0.163 \\
(0.002)\end{array}$ & $\begin{array}{l}0.184 \\
(0.010)\end{array}$ & 0.030 \\
\hline Married share of electorate & $\begin{array}{c}0.320 \\
(0.002)\end{array}$ & $\begin{array}{c}0.335 \\
(0.010)\end{array}$ & 0.111 \\
\hline Divorced share of electorate & $\begin{array}{c}0.026 \\
(0.000)\end{array}$ & $\begin{array}{c}0.030 \\
(0.002)\end{array}$ & 0.023 \\
\hline Single share of electorate & $\begin{array}{c}0.635 \\
(0.003)\end{array}$ & $\begin{array}{c}0.613 \\
(0.011)\end{array}$ & 0.043 \\
\hline $\mathrm{N}$ & 1612 & 112 & \\
\hline
\end{tabular}

Table C11: Polling stations characteristics: balance test. Control group: nonsponsored signal within $20 \mathrm{~km}$

Notes: This table compares characteristics of polling stations that get any sponsored signal (treated) to those of ones that get non-sponsored signal (control), conditional on treated and control being up to 20 kilometers apart from each other. For each treated, there may be more than one associated control. The last column report the p-value of the mean difference t-test. The variables are past PT vote share (2010, rounds 1 and 2), polling station distance from closest sponsored AM radio station's antenna, total electorate and polling station's electorate shares of male, 16-17, 18-24,25-34, 35-44, 45-59 and 60-69 years old, illiterate, incomplete elementary school, complete elementary school (or incomplete high school) and complete high school (or incomplete college), married, divorced and single. 


\begin{tabular}{|c|c|c|c|}
\hline \multicolumn{4}{|c|}{ Within $25 \mathrm{~km}$} \\
\hline & Non-sponsored & Sponsored & diff. p-value \\
\hline \multirow[t]{2}{*}{ PT vote share in 2010 (round 1 ) } & 0.508 & 0.475 & 0.037 \\
\hline & $(0.004)$ & $(0.015)$ & \\
\hline PT vote share in 2010 (round 2) & 0.567 & 0.532 & 0.032 \\
\hline \multirow{2}{*}{ Distance to closest sponsored AM station } & $(0.004)$ & $(0.015)$ & 0.008 \\
\hline & $(0.221)$ & $(0.911)$ & \\
\hline \multirow[t]{2}{*}{ Total electorate } & 1499.999 & 1566.503 & 0.517 \\
\hline & $(23.041)$ & $(107.585)$ & \\
\hline Male share of electorate & 0.492 & 0.489 & 0.282 \\
\hline \multirow[t]{2}{*}{ 16-17 years old share of electorate } & 0.015 & 0.016 & 0.616 \\
\hline & $(0.000)$ & $(0.001)$ & \\
\hline 18-24 years old share of electorate & $\begin{array}{c}0.162 \\
(0.002)\end{array}$ & $\begin{array}{c}0.179 \\
(0.007)\end{array}$ & 0.016 \\
\hline 25-34 years old share of electorate & $\begin{array}{c}0.227 \\
(0.001)\end{array}$ & $\begin{array}{c}0.228 \\
(0.005)\end{array}$ & 0.897 \\
\hline $35-44$ years old share of electorate & $\begin{array}{c}0.192 \\
(0.001)\end{array}$ & $\begin{array}{c}0.191 \\
(0.004)\end{array}$ & 0.982 \\
\hline $45-59$ years old share of electorate & $\begin{array}{c}0.229 \\
(0.001)\end{array}$ & $\begin{array}{c}0.224 \\
(0.005)\end{array}$ & 0.404 \\
\hline $60-69$ years old share of electorate & $\begin{array}{c}0.097 \\
(0.001)\end{array}$ & $\begin{array}{c}0.093 \\
(0.003)\end{array}$ & 0.267 \\
\hline Illiterate share of electorate & $\begin{array}{c}0.076 \\
(0.001)\end{array}$ & $\begin{array}{c}0.059 \\
(0.004)\end{array}$ & 0.001 \\
\hline Literate share of electorate & $\begin{array}{l}0.505 \\
(0.002)\end{array}$ & $\begin{array}{c}0.470 \\
(0.011)\end{array}$ & 0.001 \\
\hline Complete elementary school share of electorate & $\begin{array}{c}0.240 \\
(0.001)\end{array}$ & $\begin{array}{c}0.257 \\
(0.007)\end{array}$ & 0.007 \\
\hline Complete high school share of electorate & $\begin{array}{c}0.147 \\
(0.002)\end{array}$ & $\begin{array}{c}0.176 \\
(0.008)\end{array}$ & 0.000 \\
\hline Married share of electorate & $\begin{array}{c}0.324 \\
(0.002)\end{array}$ & $\begin{array}{c}0.338 \\
(0.008)\end{array}$ & 0.099 \\
\hline Divorced share of electorate & $\begin{array}{c}0.024 \\
(0.000)\end{array}$ & $\begin{array}{c}0.030 \\
(0.002)\end{array}$ & 0.000 \\
\hline Single share of electorate & $\begin{array}{c}0.633 \\
(0.002)\end{array}$ & $\begin{array}{c}0.612 \\
(0.009)\end{array}$ & 0.025 \\
\hline $\mathrm{N}$ & 2970 & 159 & \\
\hline
\end{tabular}

Table C12: Polling stations characteristics: balance test. Control group: nonsponsored signal within $25 \mathrm{~km}$

Notes: This table compares characteristics of polling stations that get any sponsored signal (treated) to those of ones that get non-sponsored signal (control), conditional on treated and control being up to 25 kilometers apart from each other. For each treated, there may be more than one associated control. The last column report the p-value of the mean difference t-test. The variables are past PT vote share (2010, rounds 1 and 2), polling station distance from closest sponsored AM radio station's antenna, total electorate and polling station's electorate shares of male, 16-17, 18-24,25-34, 35-44, 45-59 and 60-69 years old, illiterate, incomplete elementary school, complete elementary school (or incomplete high school) and complete high school (or incomplete college), married, divorced and single. 


\begin{tabular}{|c|c|c|c|}
\hline \multicolumn{4}{|c|}{ Within $30 \mathrm{~km}$} \\
\hline & Non-sponsored & Sponsored & diff. p-value \\
\hline \multirow[b]{3}{*}{ Distance to closest sponsored AM station } & $\begin{array}{c}0.509 \\
(0.003)\end{array}$ & $\begin{array}{c}0.469 \\
(0.012)\end{array}$ & 0.002 \\
\hline & $\begin{array}{c}0.565 \\
(0.003)\end{array}$ & $\begin{array}{c}0.522 \\
(0.012)\end{array}$ & 0.001 \\
\hline & $\begin{array}{l}16.905 \\
(0.176)\end{array}$ & $\begin{array}{l}13.282 \\
(0.784)\end{array}$ & 0.000 \\
\hline Total electorate & $\begin{array}{c}1536.916 \\
(17.860)\end{array}$ & $\begin{array}{c}1671.102 \\
(89.767)\end{array}$ & 0.119 \\
\hline Male share of electorate & $\begin{array}{c}0.492 \\
(0.001)\end{array}$ & $\begin{array}{c}0.490 \\
(0.002)\end{array}$ & 0.390 \\
\hline $16-17$ years old share of electorate & $\begin{array}{c}0.015 \\
(0.000)\end{array}$ & $\begin{array}{c}0.017 \\
(0.002)\end{array}$ & 0.365 \\
\hline 18-24 years old share of electorate & $\begin{array}{c}0.163 \\
(0.001)\end{array}$ & $\begin{array}{c}0.179 \\
(0.007)\end{array}$ & 0.004 \\
\hline 25-34 years old share of electorate & $\begin{array}{c}0.227 \\
(0.001)\end{array}$ & $\begin{array}{c}0.225 \\
(0.005)\end{array}$ & 0.661 \\
\hline $35-44$ years old share of electorate & $\begin{array}{c}0.191 \\
(0.001)\end{array}$ & $\begin{array}{c}0.190 \\
(0.004)\end{array}$ & 0.841 \\
\hline $45-59$ years old share of electorate & $\begin{array}{c}0.228 \\
(0.001)\end{array}$ & $\begin{array}{c}0.227 \\
(0.004)\end{array}$ & 0.756 \\
\hline $60-69$ years old share of electorate & $\begin{array}{c}0.097 \\
(0.001)\end{array}$ & $\begin{array}{c}0.094 \\
(0.003)\end{array}$ & 0.195 \\
\hline Illiterate share of electorate & $\begin{array}{c}0.077 \\
(0.001)\end{array}$ & $\begin{array}{c}0.057 \\
(0.003)\end{array}$ & 0.000 \\
\hline Literate share of electorate & $\begin{array}{c}0.512 \\
(0.002)\end{array}$ & $\begin{array}{c}0.479 \\
(0.008)\end{array}$ & 0.000 \\
\hline Complete elementary school share of electorate & $\begin{array}{c}0.237 \\
(0.001)\end{array}$ & $\begin{array}{c}0.258 \\
(0.005)\end{array}$ & 0.000 \\
\hline Complete high school share of electorate & $\begin{array}{c}0.142 \\
(0.001)\end{array}$ & $\begin{array}{l}0.170 \\
(0.006)\end{array}$ & 0.000 \\
\hline Married share of electorate & $\begin{array}{c}0.322 \\
(0.001)\end{array}$ & $\begin{array}{c}0.335 \\
(0.007)\end{array}$ & 0.072 \\
\hline Divorced share of electorate & $\begin{array}{c}0.024 \\
(0.000)\end{array}$ & $\begin{array}{c}0.029 \\
(0.001)\end{array}$ & 0.000 \\
\hline Single share of electorate & $\begin{array}{c}0.635 \\
(0.002)\end{array}$ & $\begin{array}{c}0.617 \\
(0.007)\end{array}$ & 0.018 \\
\hline $\mathrm{N}$ & 5206 & 235 & \\
\hline
\end{tabular}

Table C13: Polling stations characteristics: balance test. Control group: nonsponsored signal within $30 \mathrm{~km}$

Notes: This table compares characteristics of polling stations that get any sponsored signal (treated) to those of ones that get non-sponsored signal (control), conditional on treated and control being up to 30 kilometers apart from each other. For each treated, there may be more than one associated control. The last column report the p-value of the mean difference t-test. The variables are past PT vote share (2010, rounds 1 and 2), polling station distance from closest sponsored AM radio station's antenna, total electorate and polling station's electorate shares of male, 16-17, 18-24,25-34, 35-44, 45-59 and 60-69 years old, illiterate, incomplete elementary school, complete elementary school (or incomplete high school) and complete high school (or incomplete college), married, divorced and single. 


\begin{tabular}{|c|c|c|c|}
\hline \multicolumn{4}{|c|}{ Within $40 \mathrm{~km}$} \\
\hline & Non-sponsored & Sponsored & diff. p-value \\
\hline \multirow[b]{3}{*}{ Distance to closest sponsored AM station } & $\begin{array}{c}0.517 \\
(0.002)\end{array}$ & $\begin{array}{c}0.468 \\
(0.010)\end{array}$ & 0.000 \\
\hline & $\begin{array}{c}0.571 \\
(0.002)\end{array}$ & $\begin{array}{c}0.526 \\
(0.010)\end{array}$ & 0.000 \\
\hline & $\begin{array}{l}18.910 \\
(0.125)\end{array}$ & $\begin{array}{l}12.524 \\
(0.588)\end{array}$ & 0.000 \\
\hline Total electorate & $\begin{array}{c}1508.749 \\
(11.847)\end{array}$ & $\begin{array}{c}1694.997 \\
(75.435)\end{array}$ & 0.007 \\
\hline Male share of electorate & $\begin{array}{c}0.494 \\
(0.000)\end{array}$ & $\begin{array}{c}0.493 \\
(0.003)\end{array}$ & 0.580 \\
\hline $16-17$ years old share of electorate & $\begin{array}{c}0.016 \\
(0.000)\end{array}$ & $\begin{array}{c}0.017 \\
(0.001)\end{array}$ & 0.355 \\
\hline 18-24 years old share of electorate & $\begin{array}{c}0.163 \\
(0.001)\end{array}$ & $\begin{array}{c}0.189 \\
(0.006)\end{array}$ & 0.000 \\
\hline 25-34 years old share of electorate & $\begin{array}{c}0.225 \\
(0.001)\end{array}$ & $\begin{array}{c}0.223 \\
(0.004)\end{array}$ & 0.512 \\
\hline $35-44$ years old share of electorate & $\begin{array}{c}0.190 \\
(0.001)\end{array}$ & $\begin{array}{c}0.187 \\
(0.003)\end{array}$ & 0.238 \\
\hline $45-59$ years old share of electorate & $\begin{array}{c}0.228 \\
(0.001)\end{array}$ & $\begin{array}{c}0.225 \\
(0.003)\end{array}$ & 0.297 \\
\hline $60-69$ years old share of electorate & $\begin{array}{c}0.097 \\
(0.000)\end{array}$ & $\begin{array}{c}0.093 \\
(0.002)\end{array}$ & 0.028 \\
\hline Illiterate share of electorate & $\begin{array}{c}0.079 \\
(0.001)\end{array}$ & $\begin{array}{c}0.057 \\
(0.003)\end{array}$ & 0.000 \\
\hline Literate share of electorate & $\begin{array}{c}0.521 \\
(0.001)\end{array}$ & $\begin{array}{c}0.477 \\
(0.007)\end{array}$ & 0.000 \\
\hline Complete elementary school share of electorate & $\begin{array}{c}0.235 \\
(0.001)\end{array}$ & $\begin{array}{c}0.262 \\
(0.005)\end{array}$ & 0.000 \\
\hline Complete high school share of electorate & $\begin{array}{c}0.136 \\
(0.001)\end{array}$ & $\begin{array}{l}0.168 \\
(0.005)\end{array}$ & 0.000 \\
\hline Married share of electorate & $\begin{array}{c}0.321 \\
(0.001)\end{array}$ & $\begin{array}{c}0.330 \\
(0.005)\end{array}$ & 0.124 \\
\hline Divorced share of electorate & $\begin{array}{c}0.022 \\
(0.000)\end{array}$ & $\begin{array}{c}0.029 \\
(0.001)\end{array}$ & 0.000 \\
\hline Single share of electorate & $\begin{array}{c}0.638 \\
(0.001)\end{array}$ & $\begin{array}{c}0.622 \\
(0.006)\end{array}$ & 0.011 \\
\hline $\mathrm{N}$ & 12364 & 380 & \\
\hline
\end{tabular}

Table C14: Polling stations characteristics: balance test. Control group: nonsponsored signal within $40 \mathrm{~km}$

Notes: This table compares characteristics of polling stations that get any sponsored signal (treated) to those of ones that get non-sponsored signal (control), conditional on treated and control being up to 40 kilometers apart from each other. For each treated, there may be more than one associated control. The last column report the p-value of the mean difference t-test. The variables are past PT vote share (2010, rounds 1 and 2), polling station distance from closest sponsored AM radio station's antenna, total electorate and polling station's electorate shares of male, 16-17, 18-24,25-34, 35-44, 45-59 and 60-69 years old, illiterate, incomplete elementary school, complete elementary school (or incomplete high school) and complete high school (or incomplete college), married, divorced and single. 


\begin{tabular}{|c|c|c|c|}
\hline \multicolumn{4}{|c|}{ Within $50 \mathrm{~km}$} \\
\hline & Non-sponsored & Sponsored & diff. p-value \\
\hline \multirow[b]{3}{*}{ Distance to closest sponsored AM station } & $\begin{array}{c}0.535 \\
(0.001)\end{array}$ & $\begin{array}{c}0.468 \\
(0.008)\end{array}$ & 0.000 \\
\hline & $\begin{array}{c}0.589 \\
(0.001)\end{array}$ & $\begin{array}{c}0.535 \\
(0.008)\end{array}$ & 0.000 \\
\hline & $\begin{array}{l}20.125 \\
(0.085)\end{array}$ & $\begin{array}{l}12.279 \\
(0.506)\end{array}$ & 0.000 \\
\hline Total electorate & $\begin{array}{c}1527.545 \\
(8.021)\end{array}$ & $\begin{array}{c}1725.618 \\
(62.079)\end{array}$ & 0.000 \\
\hline Male share of electorate & $\begin{array}{c}0.493 \\
(0.000)\end{array}$ & $\begin{array}{c}0.491 \\
(0.002)\end{array}$ & 0.137 \\
\hline $16-17$ years old share of electorate & $\begin{array}{c}0.016 \\
(0.000)\end{array}$ & $\begin{array}{c}0.016 \\
(0.001)\end{array}$ & 0.836 \\
\hline 18-24 years old share of electorate & $\begin{array}{c}0.162 \\
(0.001)\end{array}$ & $\begin{array}{c}0.184 \\
(0.005)\end{array}$ & 0.000 \\
\hline 25-34 years old share of electorate & $\begin{array}{c}0.225 \\
(0.000)\end{array}$ & $\begin{array}{c}0.221 \\
(0.003)\end{array}$ & 0.215 \\
\hline $35-44$ years old share of electorate & $\begin{array}{c}0.191 \\
(0.000)\end{array}$ & $\begin{array}{c}0.190 \\
(0.002)\end{array}$ & 0.610 \\
\hline $45-59$ years old share of electorate & $\begin{array}{c}0.228 \\
(0.000)\end{array}$ & $\begin{array}{c}0.227 \\
(0.003)\end{array}$ & 0.765 \\
\hline $60-69$ years old share of electorate & $\begin{array}{c}0.098 \\
(0.000)\end{array}$ & $\begin{array}{c}0.092 \\
(0.002)\end{array}$ & 0.001 \\
\hline Illiterate share of electorate & $\begin{array}{c}0.084 \\
(0.000)\end{array}$ & $\begin{array}{c}0.058 \\
(0.002)\end{array}$ & 0.000 \\
\hline Literate share of electorate & $\begin{array}{c}0.528 \\
(0.001)\end{array}$ & $\begin{array}{c}0.479 \\
(0.006)\end{array}$ & 0.000 \\
\hline Complete elementary school share of electorate & $\begin{array}{c}0.230 \\
(0.000)\end{array}$ & $\begin{array}{c}0.261 \\
(0.004)\end{array}$ & 0.000 \\
\hline Complete high school share of electorate & $\begin{array}{c}0.131 \\
(0.000)\end{array}$ & $\begin{array}{l}0.167 \\
(0.004)\end{array}$ & 0.000 \\
\hline Married share of electorate & $\begin{array}{c}0.320 \\
(0.001)\end{array}$ & $\begin{array}{c}0.330 \\
(0.004)\end{array}$ & 0.026 \\
\hline Divorced share of electorate & $\begin{array}{c}0.022 \\
(0.000)\end{array}$ & $\begin{array}{c}0.029 \\
(0.001)\end{array}$ & 0.000 \\
\hline Single share of electorate & $\begin{array}{c}0.640 \\
(0.001)\end{array}$ & $\begin{array}{c}0.622 \\
(0.005)\end{array}$ & 0.000 \\
\hline $\mathrm{N}$ & 27045 & 571 & \\
\hline
\end{tabular}

Table C15: Polling stations characteristics: balance test. Control group: nonsponsored signal within $50 \mathrm{~km}$

Notes: This table compares characteristics of polling stations that get any sponsored signal (treated) to those of ones that get non-sponsored signal (control), conditional on treated and control being up to 50 kilometers apart from each other. For each treated, there may be more than one associated control. The last column report the p-value of the mean difference t-test. The variables are past PT vote share (2010, rounds 1 and 2), polling station distance from closest sponsored AM radio station's antenna, total electorate and polling station's electorate shares of male, 16-17, 18-24,25-34, 35-44, 45-59 and 60-69 years old, illiterate, incomplete elementary school, complete elementary school (or incomplete high school) and complete high school (or incomplete college), married, divorced and single. 


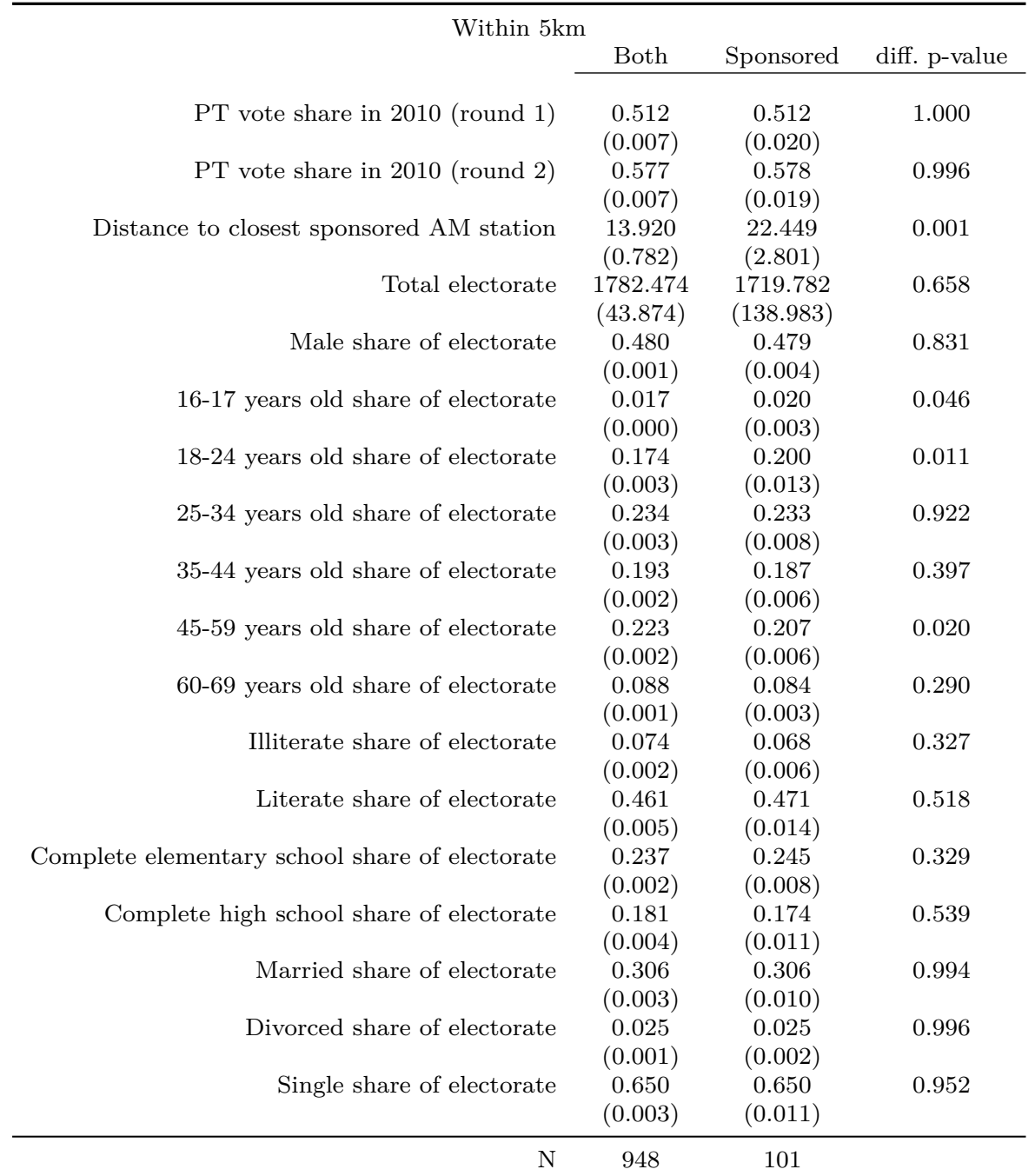

Table C16: Polling stations characteristics: balance test. Control group: nonsponsored signal or no signal within $5 \mathrm{~km}$

Notes: This table compares characteristics of polling stations that get any sponsored signal (treated) to those of ones that get non-sponsored signal or no signal (control), conditional on treated and control being up to 5 kilometers apart from each other. For each treated, there may be more than one associated control. The last column report the p-value of the mean difference t-test. The variables are past PT vote share (2010, rounds 1 and 2), polling station distance from closest sponsored AM radio station's antenna, total electorate and polling station's electorate shares of male, 16-17, 18-24,25-34, 35-44, 45-59 and 60-69 years old, illiterate, incomplete elementary school, complete elementary school (or incomplete high school) and complete high school (or incomplete college), married, divorced and single. 


\begin{tabular}{|c|c|c|c|}
\hline \multicolumn{4}{|c|}{ Within $10 \mathrm{~km}$} \\
\hline & Both & Sponsored & diff. p-value \\
\hline \multirow[b]{3}{*}{ Distance to closest sponsored AM station } & $\begin{array}{c}0.501 \\
(0.005)\end{array}$ & $\begin{array}{c}0.502 \\
(0.015)\end{array}$ & 0.993 \\
\hline & $\begin{array}{c}0.567 \\
(0.005)\end{array}$ & $\begin{array}{c}0.556 \\
(0.015)\end{array}$ & 0.532 \\
\hline & $\begin{array}{l}15.101 \\
(0.541)\end{array}$ & $\begin{array}{c}19.520 \\
(1.730)\end{array}$ & 0.009 \\
\hline Total electorate & $\begin{array}{l}1722.254 \\
(35.072)\end{array}$ & $\begin{array}{l}1678.833 \\
(105.021)\end{array}$ & 0.688 \\
\hline Male share of electorate & $\begin{array}{c}0.482 \\
(0.001)\end{array}$ & $\begin{array}{c}0.485 \\
(0.003)\end{array}$ & 0.401 \\
\hline $16-17$ years old share of electorate & $\begin{array}{c}0.016 \\
(0.000)\end{array}$ & $\begin{array}{c}0.018 \\
(0.002)\end{array}$ & 0.359 \\
\hline 18-24 years old share of electorate & $\begin{array}{c}0.170 \\
(0.002)\end{array}$ & $\begin{array}{c}0.184 \\
(0.008)\end{array}$ & 0.056 \\
\hline $25-34$ years old share of electorate & $\begin{array}{c}0.231 \\
(0.002)\end{array}$ & $\begin{array}{c}0.231 \\
(0.006)\end{array}$ & 0.978 \\
\hline $35-44$ years old share of electorate & $\begin{array}{c}0.193 \\
(0.002)\end{array}$ & $\begin{array}{c}0.188 \\
(0.004)\end{array}$ & 0.277 \\
\hline 45-59 years old share of electorate & $\begin{array}{c}0.227 \\
(0.002)\end{array}$ & $\begin{array}{c}0.218 \\
(0.004)\end{array}$ & 0.074 \\
\hline $60-69$ years old share of electorate & $\begin{array}{c}0.091 \\
(0.001)\end{array}$ & $\begin{array}{c}0.091 \\
(0.003)\end{array}$ & 0.900 \\
\hline \multirow[b]{3}{*}{ Complete elementary school share of electorate } & $\begin{array}{c}0.071 \\
(0.002)\end{array}$ & $\begin{array}{c}0.068 \\
(0.004)\end{array}$ & 0.441 \\
\hline & $\begin{array}{c}0.474 \\
(0.004)\end{array}$ & $\begin{array}{c}0.482 \\
(0.010)\end{array}$ & 0.480 \\
\hline & $\begin{array}{c}0.237 \\
(0.002)\end{array}$ & $\begin{array}{c}0.242 \\
(0.006)\end{array}$ & 0.395 \\
\hline Complete high school share of electorate & $\begin{array}{c}0.175 \\
(0.003)\end{array}$ & $\begin{array}{c}0.169 \\
(0.008)\end{array}$ & 0.490 \\
\hline Married share of electorate & $\begin{array}{c}0.312 \\
(0.003)\end{array}$ & $\begin{array}{c}0.326 \\
(0.008)\end{array}$ & 0.085 \\
\hline Divorced share of electorate & $\begin{array}{c}0.026 \\
(0.001)\end{array}$ & $\begin{array}{c}0.026 \\
(0.001)\end{array}$ & 0.779 \\
\hline Single share of electorate & $\begin{array}{c}0.643 \\
(0.003)\end{array}$ & $\begin{array}{c}0.628 \\
(0.009)\end{array}$ & 0.107 \\
\hline $\mathrm{N}$ & 1474 & 174 & \\
\hline
\end{tabular}

Table C17: Polling stations characteristics: balance test. Control group: nonsponsored or no signal within $10 \mathrm{~km}$

Notes: This table compares characteristics of polling stations that get any sponsored signal (treated) to those of ones that get non-sponsored signal or no signal (control), conditional on treated and control being up to 10 kilometers apart from each other. For each treated, there may be more than one associated control. The last column report the p-value of the mean difference t-test. The variables are past PT vote share (2010, rounds 1 and 2), polling station distance from closest sponsored AM radio station's antenna, total electorate and polling station's electorate shares of male, 16-17, 18-24,25-34, 35-44, 45-59 and 60-69 years old, illiterate, incomplete elementary school, complete elementary school (or incomplete high school) and complete high school (or incomplete college), married, divorced and single. 


\begin{tabular}{|c|c|c|c|}
\hline \multicolumn{4}{|c|}{ Within $15 \mathrm{~km}$} \\
\hline & Both & Sponsored & diff. p-value \\
\hline \multirow[b]{3}{*}{ Distance to closest sponsored AM station } & $\begin{array}{c}0.510 \\
(0.004)\end{array}$ & $\begin{array}{c}0.507 \\
(0.010)\end{array}$ & 0.775 \\
\hline & $\begin{array}{c}0.572 \\
(0.004)\end{array}$ & $\begin{array}{c}0.561 \\
(0.010)\end{array}$ & 0.344 \\
\hline & $\begin{array}{l}16.865 \\
(0.335)\end{array}$ & $\begin{array}{l}17.549 \\
(1.028)\end{array}$ & 0.509 \\
\hline Total electorate & $\begin{array}{l}1664.631 \\
(24.934)\end{array}$ & $\begin{array}{l}1635.117 \\
(72.540)\end{array}$ & 0.700 \\
\hline Male share of electorate & $\begin{array}{c}0.488 \\
(0.001)\end{array}$ & $\begin{array}{c}0.491 \\
(0.002)\end{array}$ & 0.188 \\
\hline 16-17 years old share of electorate & $\begin{array}{c}0.016 \\
(0.000)\end{array}$ & $\begin{array}{c}0.016 \\
(0.001)\end{array}$ & 0.883 \\
\hline 18-24 years old share of electorate & $\begin{array}{c}0.167 \\
(0.002)\end{array}$ & $\begin{array}{c}0.174 \\
(0.005)\end{array}$ & 0.124 \\
\hline $25-34$ years old share of electorate & $\begin{array}{c}0.229 \\
(0.001)\end{array}$ & $\begin{array}{c}0.227 \\
(0.004)\end{array}$ & 0.622 \\
\hline $35-44$ years old share of electorate & $\begin{array}{c}0.192 \\
(0.001)\end{array}$ & $\begin{array}{c}0.187 \\
(0.003)\end{array}$ & 0.138 \\
\hline 45-59 years old share of electorate & $\begin{array}{c}0.228 \\
(0.001)\end{array}$ & $\begin{array}{c}0.227 \\
(0.003)\end{array}$ & 0.748 \\
\hline $60-69$ years old share of electorate & $\begin{array}{c}0.094 \\
(0.001)\end{array}$ & $\begin{array}{c}0.095 \\
(0.002)\end{array}$ & 0.813 \\
\hline \multirow[b]{3}{*}{ Complete elementary school share of electorate } & $\begin{array}{c}0.076 \\
(0.001)\end{array}$ & $\begin{array}{c}0.071 \\
(0.003)\end{array}$ & 0.229 \\
\hline & $\begin{array}{c}0.493 \\
(0.003)\end{array}$ & $\begin{array}{c}0.496 \\
(0.007)\end{array}$ & 0.750 \\
\hline & $\begin{array}{c}0.234 \\
(0.001)\end{array}$ & $\begin{array}{c}0.243 \\
(0.004)\end{array}$ & 0.033 \\
\hline Complete high school share of electorate & $\begin{array}{c}0.161 \\
(0.002)\end{array}$ & $\begin{array}{c}0.157 \\
(0.005)\end{array}$ & 0.493 \\
\hline Married share of electorate & $\begin{array}{c}0.318 \\
(0.002)\end{array}$ & $\begin{array}{c}0.335 \\
(0.006)\end{array}$ & 0.006 \\
\hline Divorced share of electorate & $\begin{array}{l}0.025 \\
(0.000)\end{array}$ & $\begin{array}{c}0.025 \\
(0.001)\end{array}$ & 0.902 \\
\hline Single share of electorate & $\begin{array}{c}0.637 \\
(0.002)\end{array}$ & $\begin{array}{c}0.621 \\
(0.006)\end{array}$ & 0.015 \\
\hline $\mathrm{N}$ & 2798 & 332 & \\
\hline
\end{tabular}

Table C18: Polling stations characteristics: balance test. Control group: nonsponsored or no signal within $15 \mathrm{~km}$

Notes: This table compares characteristics of polling stations that get any sponsored signal (treated) to those of ones that get non-sponsored signal or no signal (control), conditional on treated and control being up to 15 kilometers apart from each other. For each treated, there may be more than one associated control. The last column report the p-value of the mean difference t-test. The variables are past PT vote share (2010, rounds 1 and 2), polling station distance from closest sponsored AM radio station's antenna, total electorate and polling station's electorate shares of male, 16-17, 18-24,25-34, 35-44, 45-59 and 60-69 years old, illiterate, incomplete elementary school, complete elementary school (or incomplete high school) and complete high school (or incomplete college), married, divorced and single. 


\begin{tabular}{|c|c|c|c|}
\hline \multicolumn{4}{|c|}{ Within $20 \mathrm{~km}$} \\
\hline & Both & Sponsored & diff. p-value \\
\hline \multirow[b]{3}{*}{ Distance to closest sponsored AM station } & $\begin{array}{c}0.516 \\
(0.003)\end{array}$ & $\begin{array}{c}0.492 \\
(0.009)\end{array}$ & 0.009 \\
\hline & $\begin{array}{c}0.574 \\
(0.003)\end{array}$ & $\begin{array}{c}0.545 \\
(0.009)\end{array}$ & 0.002 \\
\hline & $\begin{array}{l}17.922 \\
(0.222)\end{array}$ & $\begin{array}{l}16.482 \\
(0.756)\end{array}$ & 0.050 \\
\hline Total electorate & $\begin{array}{l}1603.443 \\
(18.234)\end{array}$ & $\begin{array}{l}1627.881 \\
(58.498)\end{array}$ & 0.684 \\
\hline Male share of electorate & $\begin{array}{c}0.490 \\
(0.001)\end{array}$ & $\begin{array}{c}0.492 \\
(0.002)\end{array}$ & 0.390 \\
\hline $16-17$ years old share of electorate & $\begin{array}{c}0.016 \\
(0.000)\end{array}$ & $\begin{array}{c}0.016 \\
(0.001)\end{array}$ & 0.742 \\
\hline 18-24 years old share of electorate & $\begin{array}{c}0.163 \\
(0.001)\end{array}$ & $\begin{array}{c}0.176 \\
(0.004)\end{array}$ & 0.001 \\
\hline $25-34$ years old share of electorate & $\begin{array}{c}0.228 \\
(0.001)\end{array}$ & $\begin{array}{c}0.227 \\
(0.003)\end{array}$ & 0.973 \\
\hline $35-44$ years old share of electorate & $\begin{array}{c}0.190 \\
(0.001)\end{array}$ & $\begin{array}{c}0.188 \\
(0.002)\end{array}$ & 0.413 \\
\hline 45-59 years old share of electorate & $\begin{array}{c}0.228 \\
(0.001)\end{array}$ & $\begin{array}{c}0.225 \\
(0.003)\end{array}$ & 0.308 \\
\hline $60-69$ years old share of electorate & $\begin{array}{c}0.096 \\
(0.001)\end{array}$ & $\begin{array}{c}0.094 \\
(0.002)\end{array}$ & 0.205 \\
\hline Illiterate share of electorate & $\begin{array}{c}0.078 \\
(0.001)\end{array}$ & $\begin{array}{c}0.067 \\
(0.002)\end{array}$ & 0.000 \\
\hline \multirow[b]{2}{*}{ Complete elementary school share of electorate } & $\begin{array}{c}0.509 \\
(0.002)\end{array}$ & $\begin{array}{c}0.498 \\
(0.006)\end{array}$ & 0.063 \\
\hline & $\begin{array}{c}0.234 \\
(0.001)\end{array}$ & $\begin{array}{c}0.251 \\
(0.004)\end{array}$ & 0.000 \\
\hline Complete high school share of electorate & $\begin{array}{c}0.148 \\
(0.001)\end{array}$ & $\begin{array}{c}0.155 \\
(0.004)\end{array}$ & 0.130 \\
\hline Married share of electorate & $\begin{array}{c}0.321 \\
(0.001)\end{array}$ & $\begin{array}{c}0.335 \\
(0.005)\end{array}$ & 0.002 \\
\hline Divorced share of electorate & $\begin{array}{c}0.023 \\
(0.000)\end{array}$ & $\begin{array}{c}0.025 \\
(0.001)\end{array}$ & 0.040 \\
\hline Single share of electorate & $\begin{array}{c}0.637 \\
(0.002)\end{array}$ & $\begin{array}{c}0.621 \\
(0.005)\end{array}$ & 0.002 \\
\hline $\mathrm{N}$ & 5109 & 523 & \\
\hline
\end{tabular}

Table C19: Polling stations characteristics: balance test. Control group: nonsponsored or no signal within $20 \mathrm{~km}$

Notes: This table compares characteristics of polling stations that get any sponsored signal (treated) to those of ones that get non-sponsored signal or no signal (control), conditional on treated and control being up to 20 kilometers apart from each other. For each treated, there may be more than one associated control. The last column report the p-value of the mean difference t-test. The variables are past PT vote share (2010, rounds 1 and 2), polling station distance from closest sponsored AM radio station's antenna, total electorate and polling station's electorate shares of male, 16-17, 18-24,25-34, 35-44, 45-59 and 60-69 years old, illiterate, incomplete elementary school, complete elementary school (or incomplete high school) and complete high school (or incomplete college), married, divorced and single. 


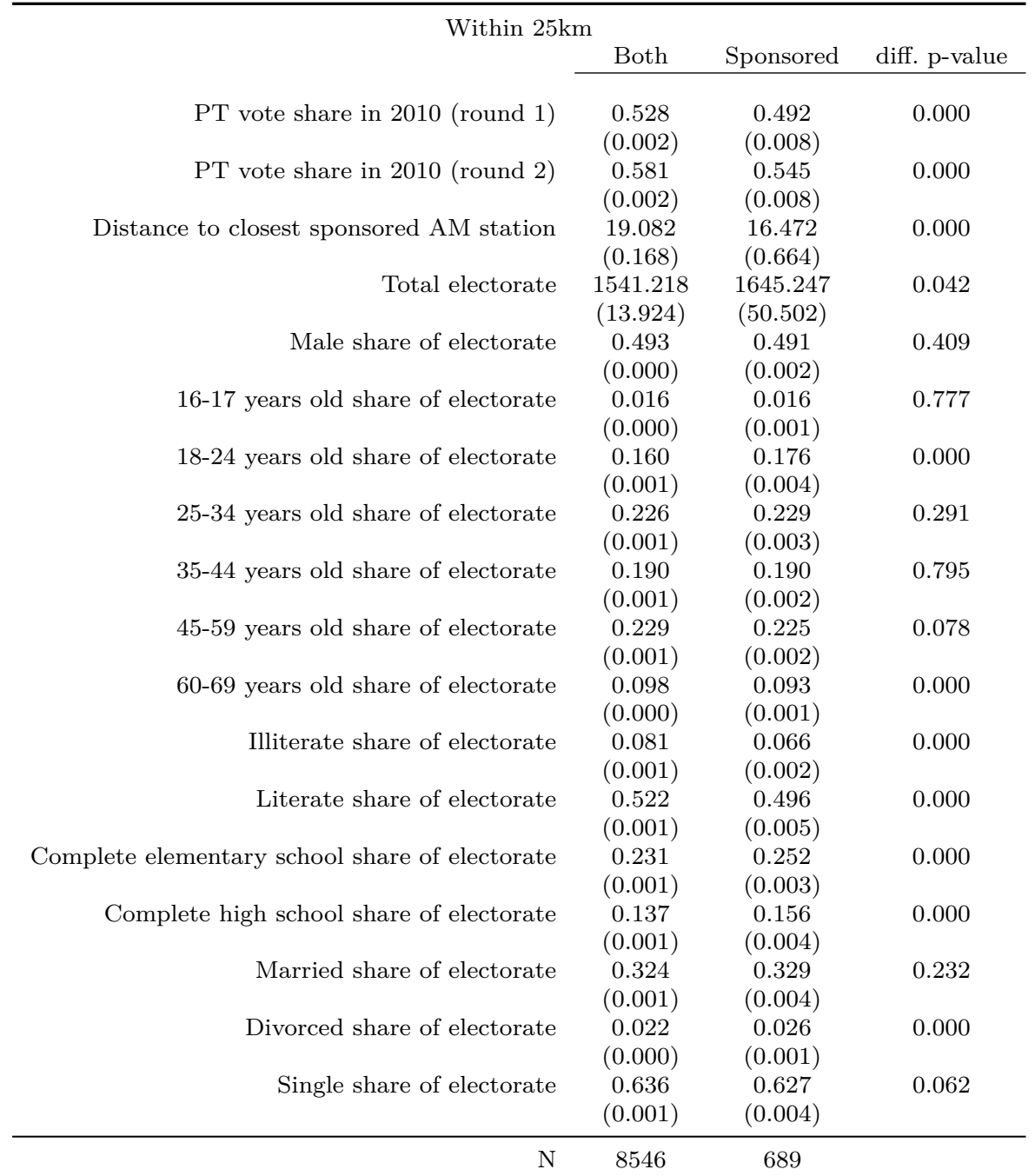

Table C20: Polling stations characteristics: balance test. Control group: nonsponsored or no signal within $25 \mathrm{~km}$

Notes: This table compares characteristics of polling stations that get any sponsored signal (treated) to those of ones that get non-sponsored signal or no signal (control), conditional on treated and control being up to 25 kilometers apart from each other. For each treated, there may be more than one associated control. The last column report the p-value of the mean difference t-test. The variables are past PT vote share (2010, rounds 1 and 2), polling station distance from closest sponsored AM radio station's antenna, total electorate and polling station's electorate shares of male, 16-17, 18-24,25-34, 35-44, 45-59 and 60-69 years old, illiterate, incomplete elementary school, complete elementary school (or incomplete high school) and complete high school (or incomplete college), married, divorced and single. 


\begin{tabular}{|c|c|c|c|}
\hline \multicolumn{4}{|c|}{ Within $30 \mathrm{~km}$} \\
\hline & Both & Sponsored & diff. p-value \\
\hline PT vote share in 2010 (round 1 ) & $\begin{array}{c}0.530 \\
(0.002)\end{array}$ & $\begin{array}{c}0.486 \\
(0.007)\end{array}$ & 0.000 \\
\hline PT vote share in 2010 (round 2) & $\begin{array}{c}0.582 \\
(0.002)\end{array}$ & $\begin{array}{c}0.540 \\
(0.007)\end{array}$ & 0.000 \\
\hline Distance to sponsored AM station & $\begin{array}{l}19.844 \\
(0.132)\end{array}$ & $\begin{array}{l}15.845 \\
(0.571)\end{array}$ & 0.000 \\
\hline Total electorate & $\begin{array}{c}1549.276 \\
(11.215)\end{array}$ & $\begin{array}{l}1643.010 \\
(45.446)\end{array}$ & 0.040 \\
\hline Male share of electorate & $\begin{array}{c}0.493 \\
(0.000)\end{array}$ & $\begin{array}{c}0.492 \\
(0.002)\end{array}$ & 0.439 \\
\hline 16-17 years old share of electorate & $\begin{array}{c}0.016 \\
(0.000)\end{array}$ & $\begin{array}{c}0.015 \\
(0.001)\end{array}$ & 0.566 \\
\hline 18-24 years old share of electorate & $\begin{array}{c}0.160 \\
(0.001)\end{array}$ & $\begin{array}{c}0.179 \\
(0.004)\end{array}$ & 0.000 \\
\hline $25-34$ years old share of electorate & $\begin{array}{c}0.226 \\
(0.001)\end{array}$ & $\begin{array}{c}0.228 \\
(0.003)\end{array}$ & 0.474 \\
\hline $35-44$ years old share of electorate & $\begin{array}{c}0.190 \\
(0.000)\end{array}$ & $\begin{array}{c}0.190 \\
(0.002)\end{array}$ & 0.711 \\
\hline $45-59$ years old share of electorate & $\begin{array}{c}0.229 \\
(0.001)\end{array}$ & $\begin{array}{c}0.225 \\
(0.002)\end{array}$ & 0.039 \\
\hline $60-69$ years old share of electorate & $\begin{array}{c}0.098 \\
(0.000)\end{array}$ & $\begin{array}{c}0.092 \\
(0.001)\end{array}$ & 0.000 \\
\hline Illiterate share of electorate & $\begin{array}{c}0.082 \\
(0.001)\end{array}$ & $\begin{array}{c}0.064 \\
(0.002)\end{array}$ & 0.000 \\
\hline Literate share of electorate & $\begin{array}{c}0.526 \\
(0.001)\end{array}$ & $\begin{array}{c}0.491 \\
(0.005)\end{array}$ & 0.000 \\
\hline Complete elementary school share of electorate & $\begin{array}{c}0.231 \\
(0.001)\end{array}$ & $\begin{array}{c}0.256 \\
(0.003)\end{array}$ & 0.000 \\
\hline Complete high school share of electorate & $\begin{array}{c}0.134 \\
(0.001)\end{array}$ & $\begin{array}{c}0.158 \\
(0.003)\end{array}$ & 0.000 \\
\hline Married share of electorate & $\begin{array}{c}0.324 \\
(0.001)\end{array}$ & $\begin{array}{c}0.327 \\
(0.004)\end{array}$ & 0.511 \\
\hline Divorced share of electorate & $\begin{array}{c}0.022 \\
(0.000)\end{array}$ & $\begin{array}{c}0.026 \\
(0.001)\end{array}$ & 0.000 \\
\hline Single share of electorate & $\begin{array}{c}0.635 \\
(0.001)\end{array}$ & $\begin{array}{c}0.629 \\
(0.004)\end{array}$ & 0.115 \\
\hline $\mathrm{N}$ & 13317 & 857 & \\
\hline
\end{tabular}

Table C21: Polling stations characteristics: balance test. Control group: nonsponsored or no signal within $30 \mathrm{~km}$

Notes: This table compares characteristics of polling stations that get any sponsored signal (treated) to those of ones that get non-sponsored signal or no signal (control), conditional on treated and control being up to 30 kilometers apart from each other. For each treated, there may be more than one associated control. The last column report the p-value of the mean difference t-test. The variables are past PT vote share (2010, rounds 1 and 2), polling station distance from closest sponsored AM radio station's antenna, total electorate and polling station's electorate shares of male, 16-17, 18-24,25-34, 35-44, 45-59 and 60-69 years old, illiterate, incomplete elementary school, complete elementary school (or incomplete high school) and complete high school (or incomplete college), married, divorced and single. 


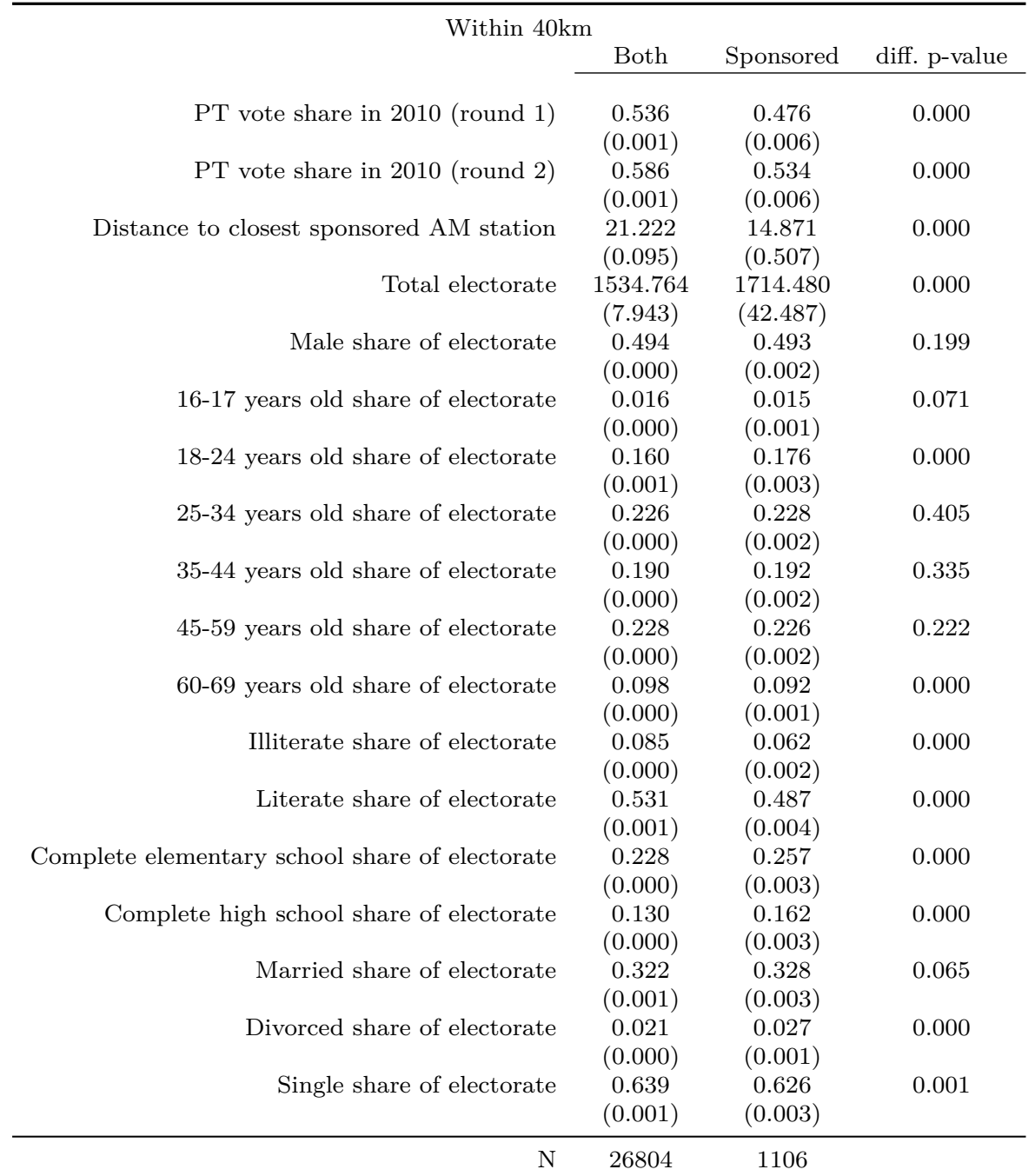

Table C22: Polling stations characteristics: balance test. Control group: nonsponsored or no signal within $40 \mathrm{~km}$

Notes: This table compares characteristics of polling stations that get any sponsored signal (treated) to those of ones that get non-sponsored signal or no signal (control), conditional on treated and control being up to 40 kilometers apart from each other. For each treated, there may be more than one associated control. The last column report the p-value of the mean difference t-test. The variables are past PT vote share (2010, rounds 1 and 2), polling station distance from closest sponsored AM radio station's antenna, total electorate and polling station's electorate shares of male, 16-17, 18-24,25-34, 35-44, 45-59 and 60-69 years old, illiterate, incomplete elementary school, complete elementary school (or incomplete high school) and complete high school (or incomplete college), married, divorced and single. 


\begin{tabular}{|c|c|c|c|}
\hline \multicolumn{4}{|c|}{ Within $50 \mathrm{~km}$} \\
\hline & Both & Sponsored & diff. p-value \\
\hline \multirow[b]{3}{*}{ Distance to closest sponsored AM station } & $\begin{array}{c}0.539 \\
(0.001)\end{array}$ & $\begin{array}{c}0.470 \\
(0.006)\end{array}$ & 0.000 \\
\hline & $\begin{array}{c}0.590 \\
(0.001)\end{array}$ & $\begin{array}{c}0.531 \\
(0.006)\end{array}$ & 0.000 \\
\hline & $\begin{array}{l}22.107 \\
(0.074)\end{array}$ & $\begin{array}{l}14.787 \\
(0.506)\end{array}$ & 0.000 \\
\hline Total electorate & $\begin{array}{c}1515.133 \\
(6.064)\end{array}$ & $\begin{array}{l}1750.035 \\
(40.744)\end{array}$ & 0.000 \\
\hline Male share of electorate & $\begin{array}{c}0.495 \\
(0.000)\end{array}$ & $\begin{array}{c}0.492 \\
(0.002)\end{array}$ & 0.012 \\
\hline $16-17$ years old share of electorate & $\begin{array}{c}0.016 \\
(0.000)\end{array}$ & $\begin{array}{c}0.015 \\
(0.001)\end{array}$ & 0.026 \\
\hline 18-24 years old share of electorate & $\begin{array}{c}0.160 \\
(0.000)\end{array}$ & $\begin{array}{c}0.176 \\
(0.003)\end{array}$ & 0.000 \\
\hline $25-34$ years old share of electorate & $\begin{array}{c}0.225 \\
(0.000)\end{array}$ & $\begin{array}{c}0.230 \\
(0.002)\end{array}$ & 0.024 \\
\hline $35-44$ years old share of electorate & $\begin{array}{c}0.191 \\
(0.000)\end{array}$ & $\begin{array}{c}0.192 \\
(0.002)\end{array}$ & 0.407 \\
\hline 45-59 years old share of electorate & $\begin{array}{c}0.228 \\
(0.000)\end{array}$ & $\begin{array}{c}0.226 \\
(0.002)\end{array}$ & 0.175 \\
\hline $60-69$ years old share of electorate & $\begin{array}{c}0.098 \\
(0.000)\end{array}$ & $\begin{array}{c}0.092 \\
(0.001)\end{array}$ & 0.000 \\
\hline Illiterate share of electorate & $\begin{array}{c}0.086 \\
(0.000)\end{array}$ & $\begin{array}{c}0.059 \\
(0.002)\end{array}$ & 0.000 \\
\hline \multirow[b]{2}{*}{ Complete elementary school share of electorate } & $\begin{array}{c}0.533 \\
(0.001)\end{array}$ & $\begin{array}{c}0.483 \\
(0.004)\end{array}$ & 0.000 \\
\hline & $\begin{array}{c}0.228 \\
(0.000)\end{array}$ & $\begin{array}{c}0.258 \\
(0.002)\end{array}$ & 0.000 \\
\hline Complete high school share of electorate & $\begin{array}{c}0.128 \\
(0.000)\end{array}$ & $\begin{array}{c}0.166 \\
(0.003)\end{array}$ & 0.000 \\
\hline Married share of electorate & $\begin{array}{c}0.321 \\
(0.001)\end{array}$ & $\begin{array}{c}0.328 \\
(0.003)\end{array}$ & 0.038 \\
\hline Divorced share of electorate & $\begin{array}{c}0.021 \\
(0.000)\end{array}$ & $\begin{array}{c}0.028 \\
(0.001)\end{array}$ & 0.000 \\
\hline Single share of electorate & $\begin{array}{l}0.640 \\
(0.001)\end{array}$ & $\begin{array}{c}0.625 \\
(0.003)\end{array}$ & 0.000 \\
\hline $\mathrm{N}$ & 44886 & 1232 & \\
\hline
\end{tabular}

Table C23: Polling stations characteristics: balance test. Control group: nonsponsored or no signal within $50 \mathrm{~km}$

Notes: This table compares characteristics of polling stations that get any sponsored signal (treated) to those of ones that get non-sponsored signal or no signal (control), conditional on treated and control being up to 50 kilometers apart from each other. For each treated, there may be more than one associated control. The last column report the p-value of the mean difference t-test. The variables are past PT vote share (2010, rounds 1 and 2), polling station distance from closest sponsored AM radio station's antenna, total electorate and polling station's electorate shares of male, 16-17, 18-24,25-34, 35-44, 45-59 and 60-69 years old, illiterate, incomplete elementary school, complete elementary school (or incomplete high school) and complete high school (or incomplete college), married, divorced and single. 


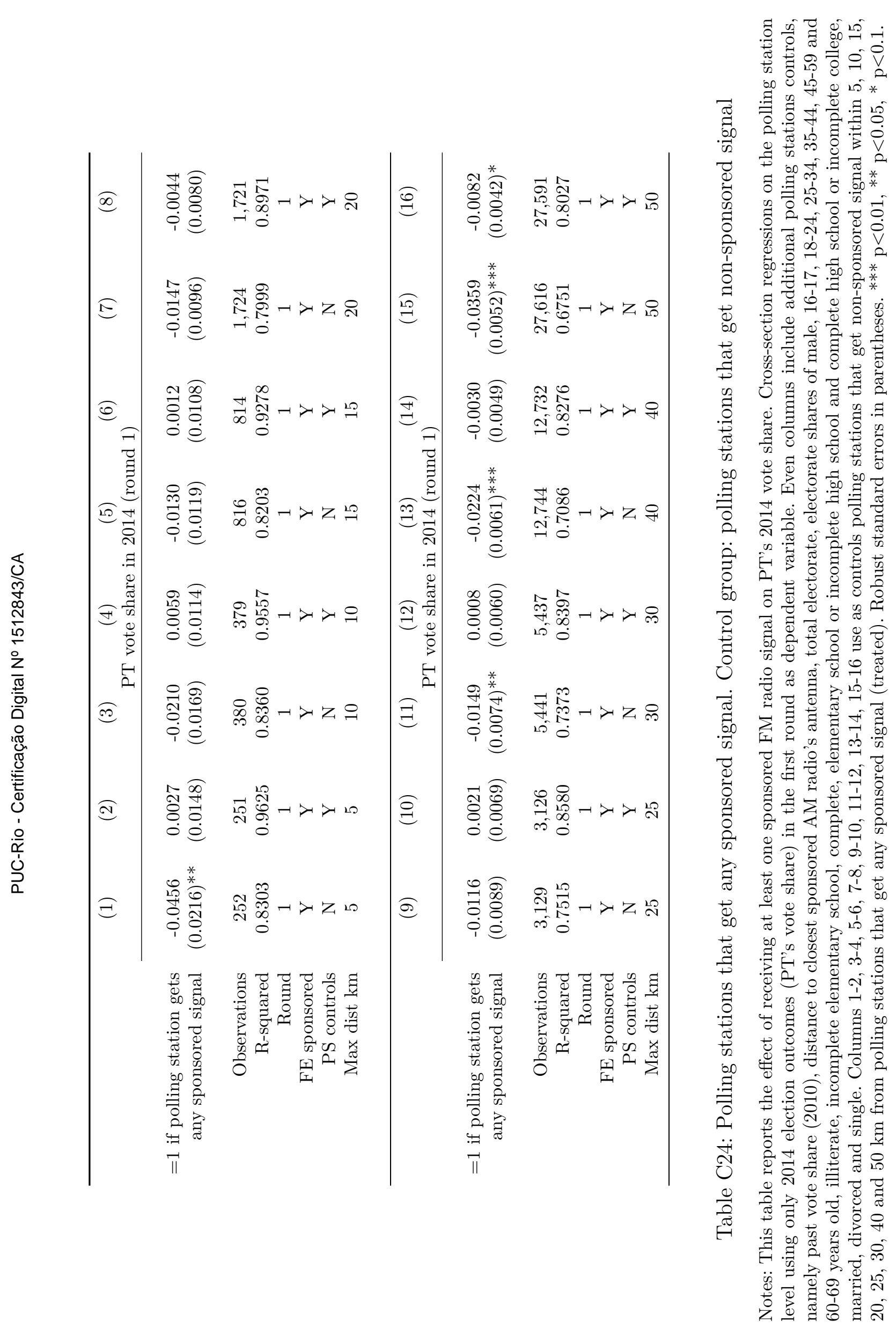




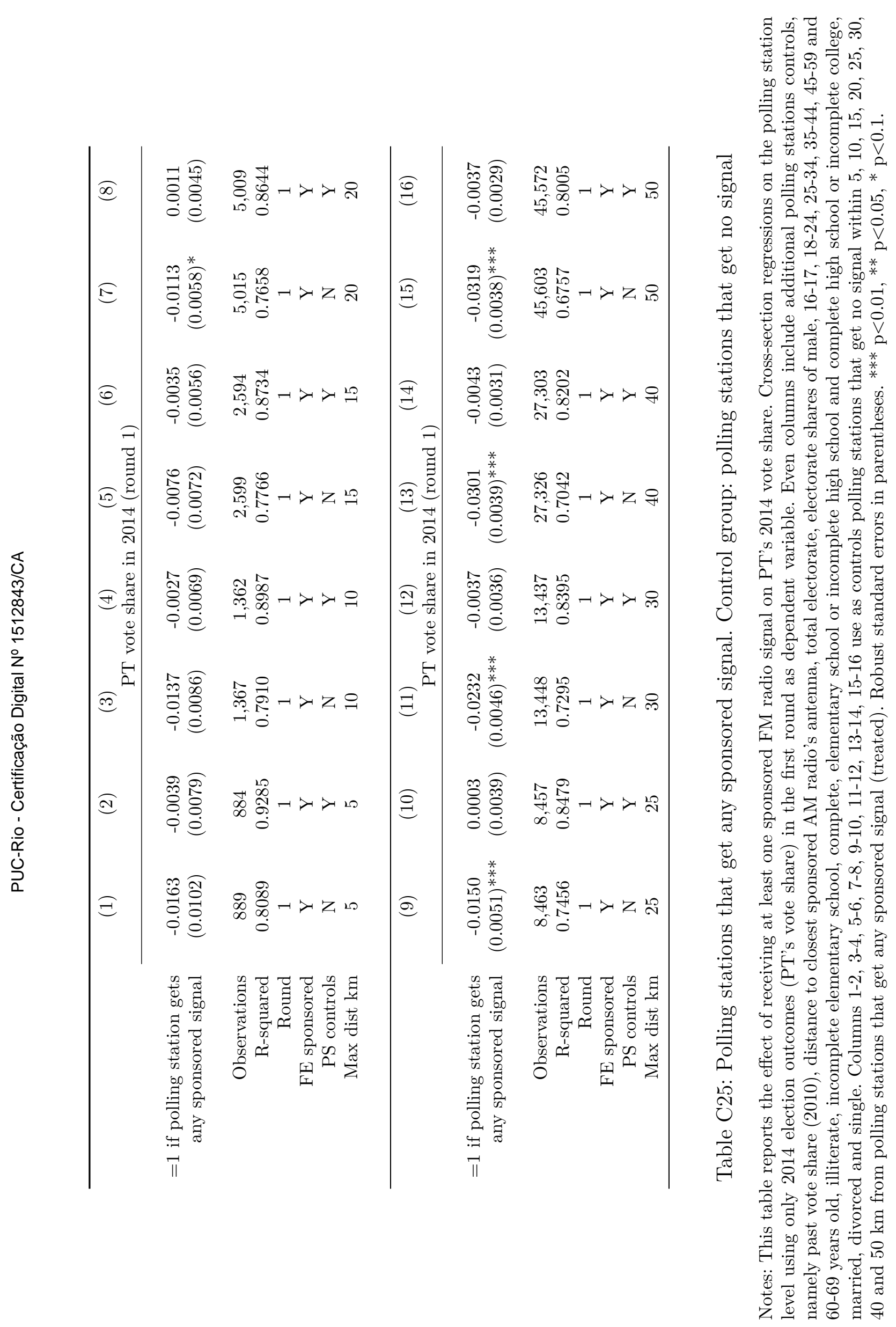




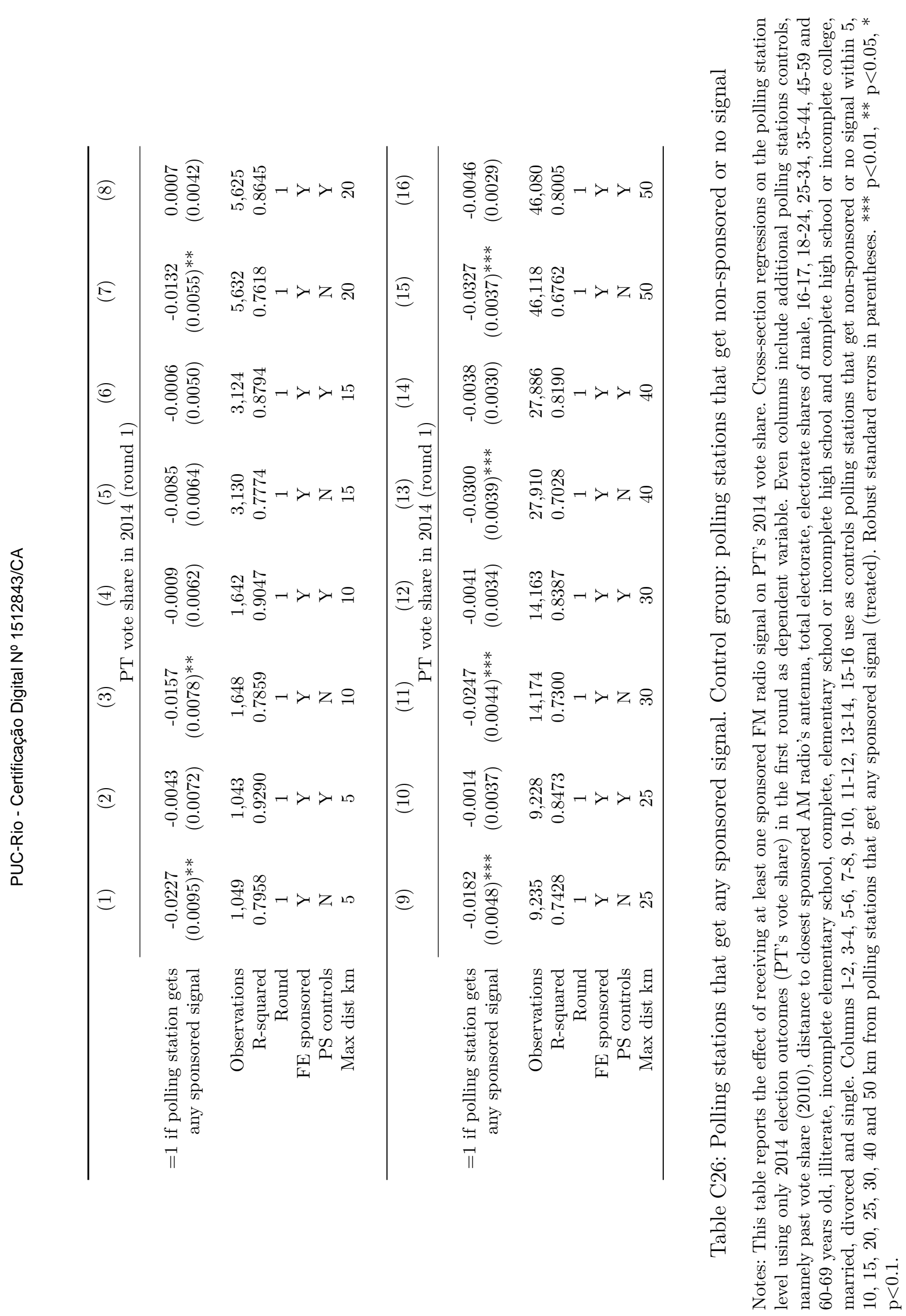




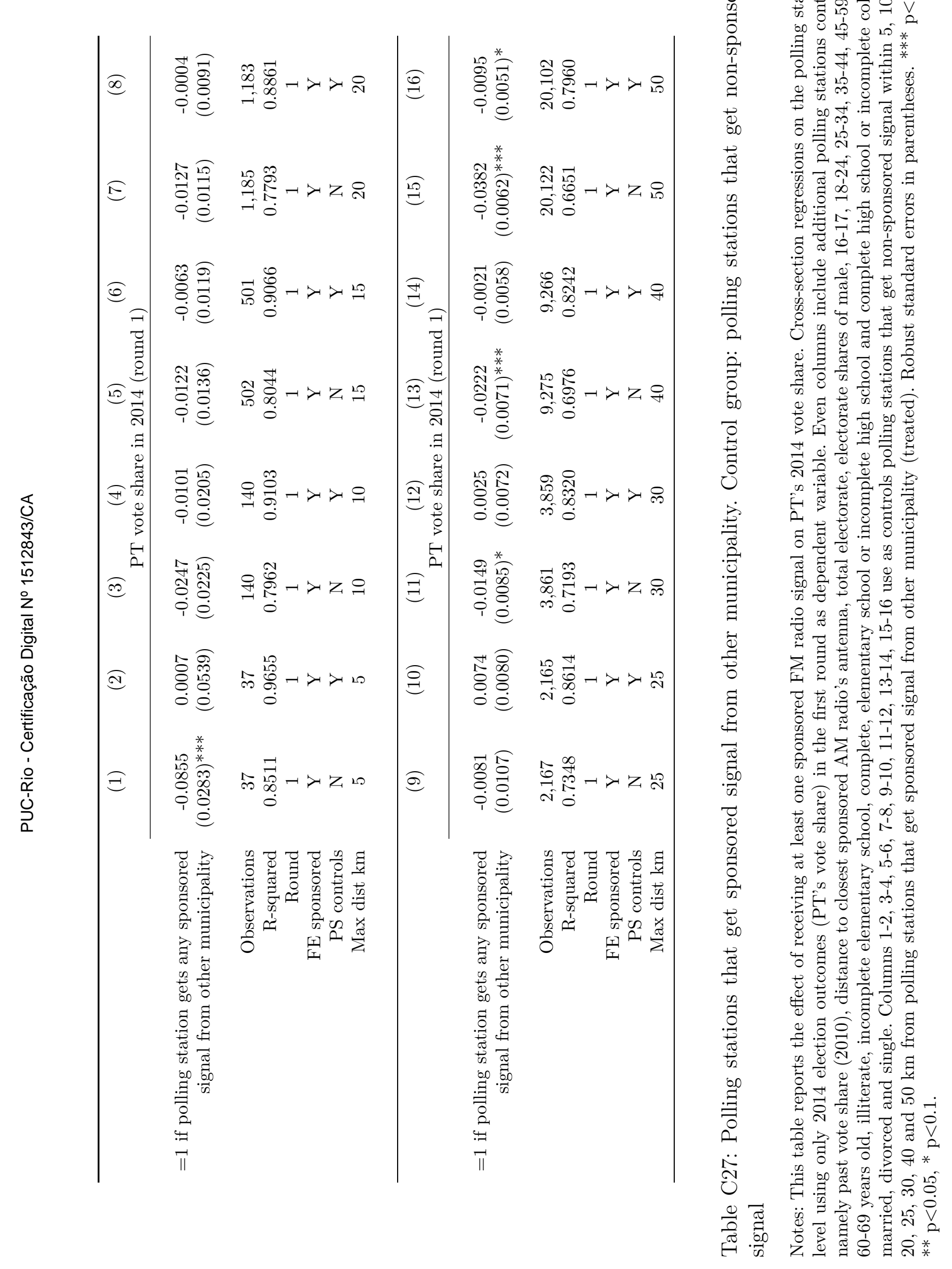




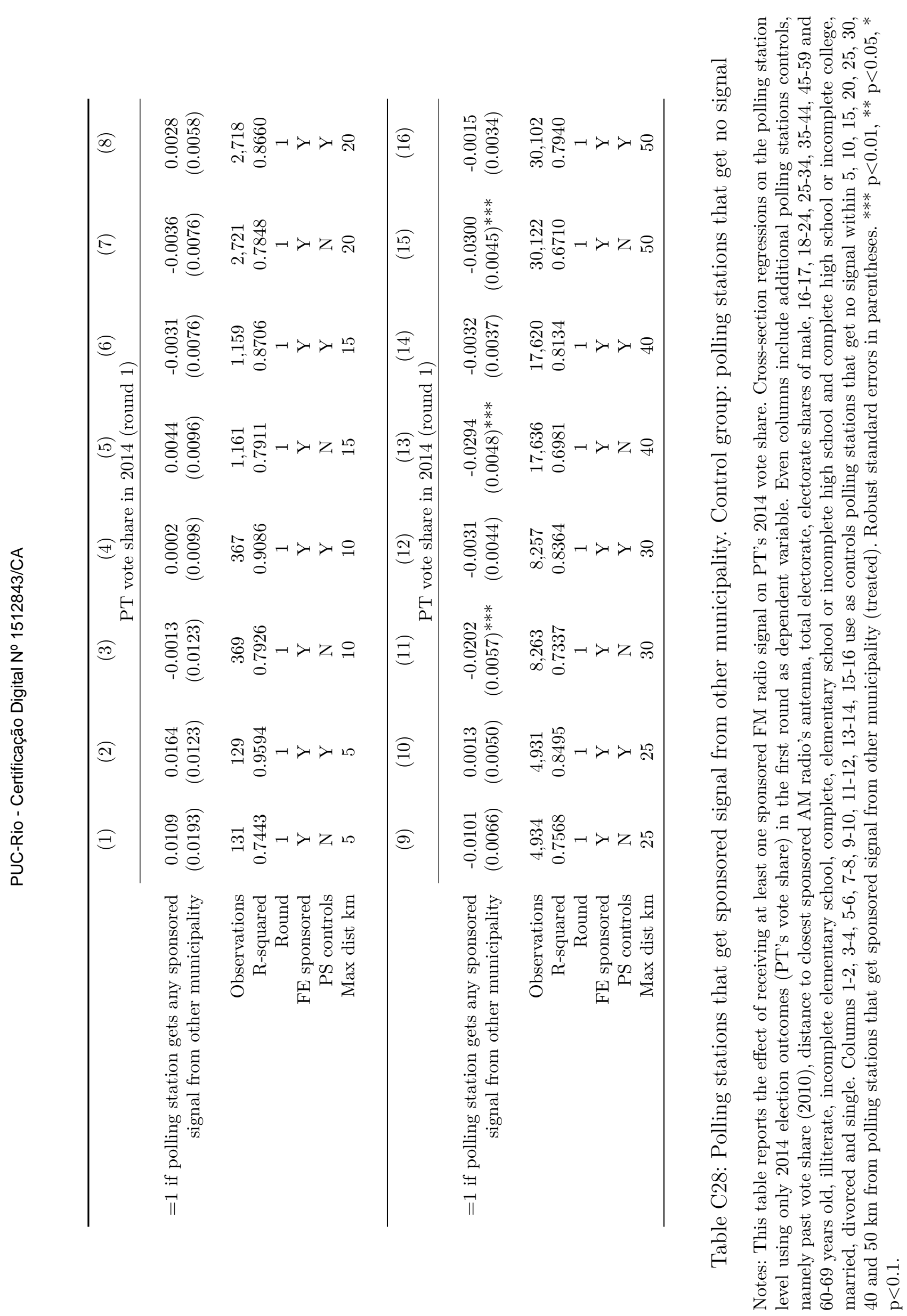




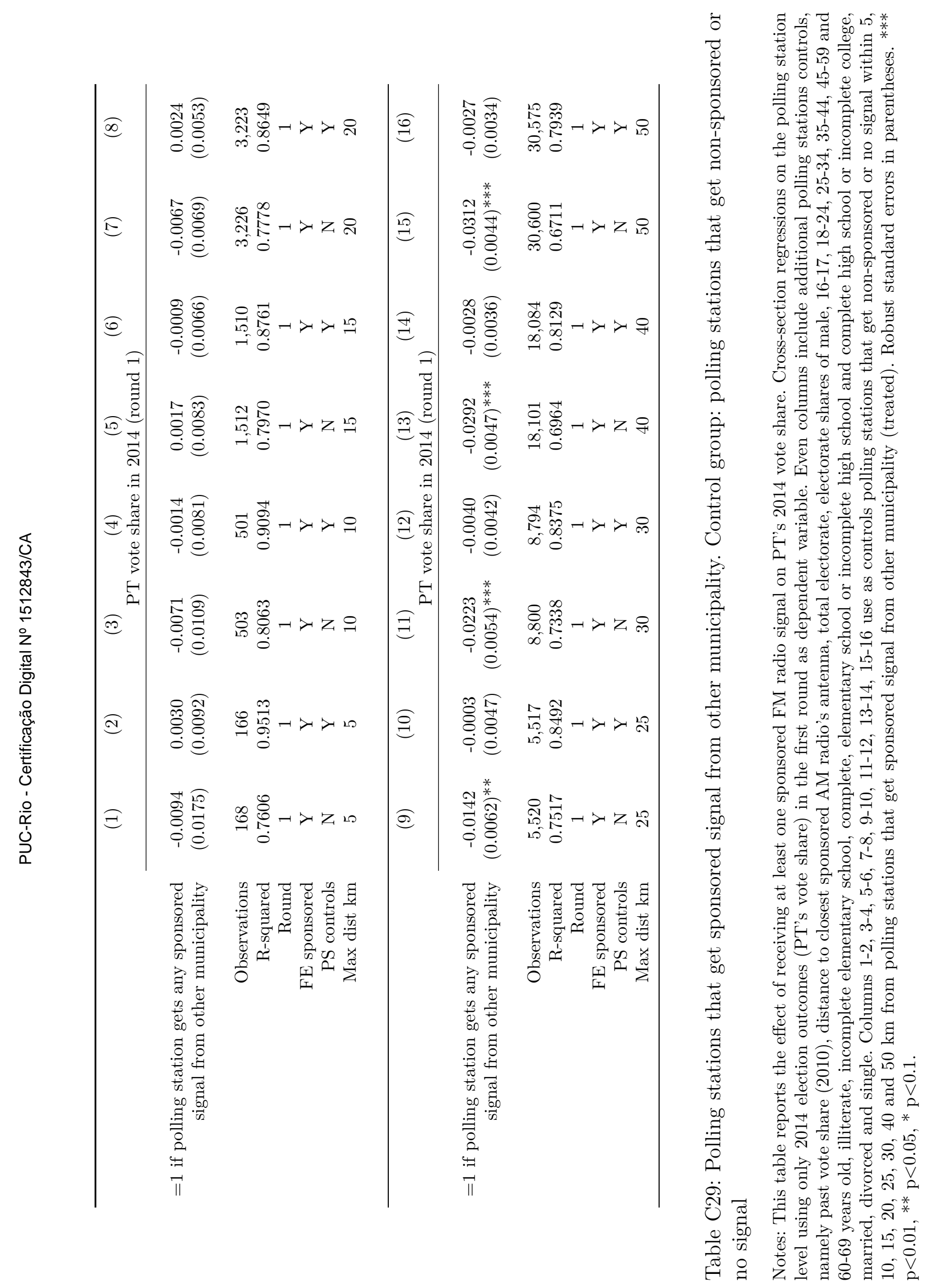




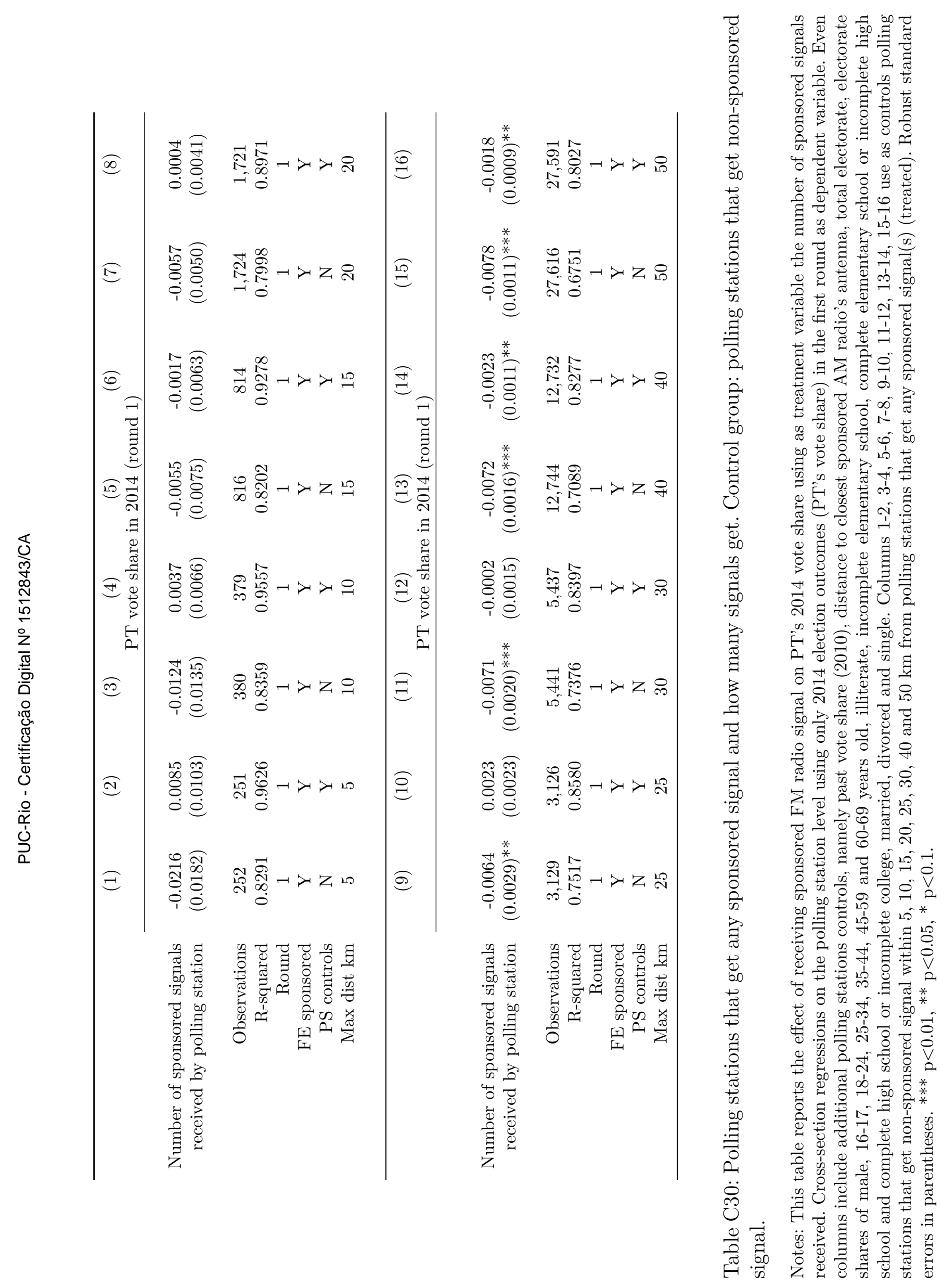




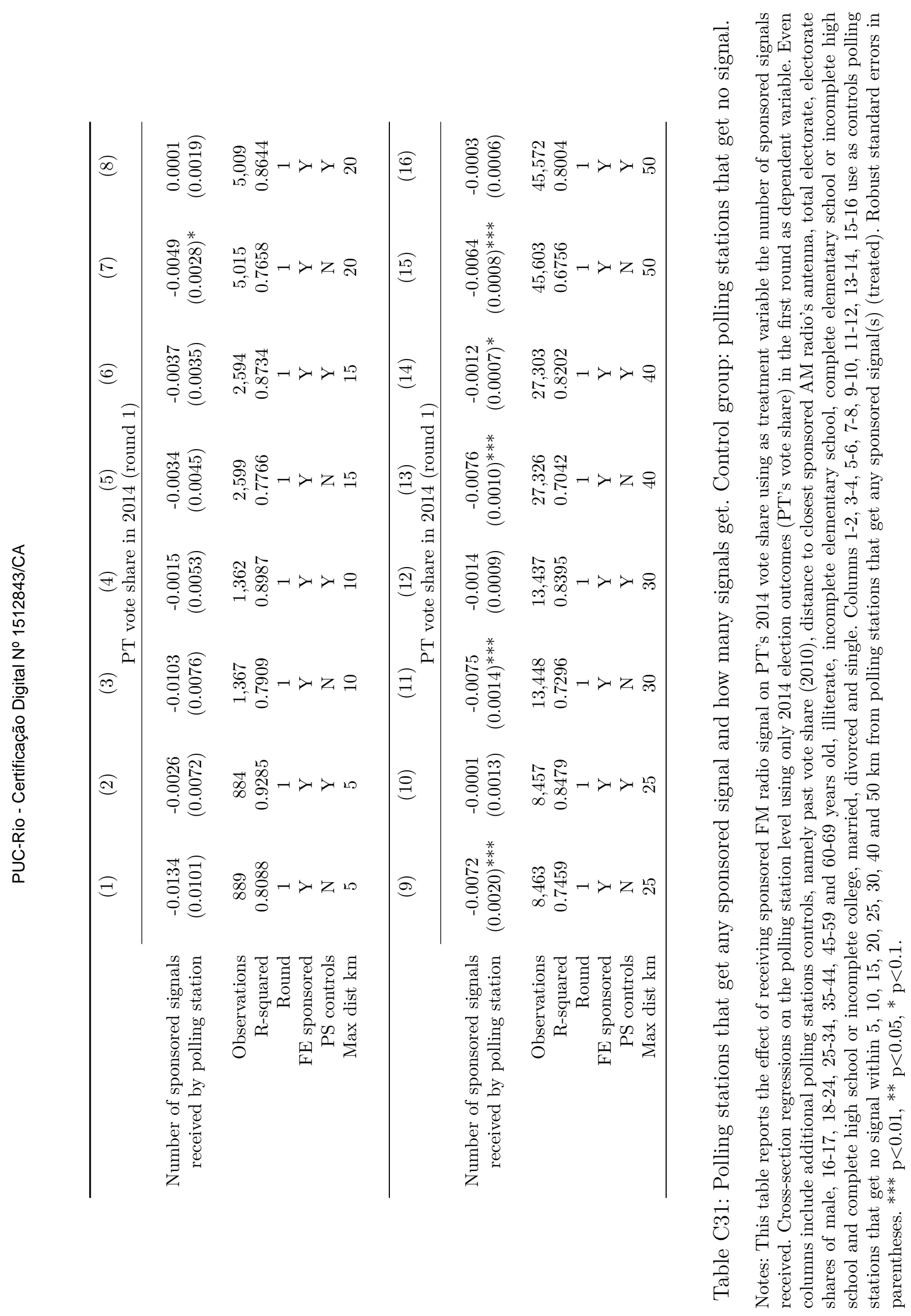




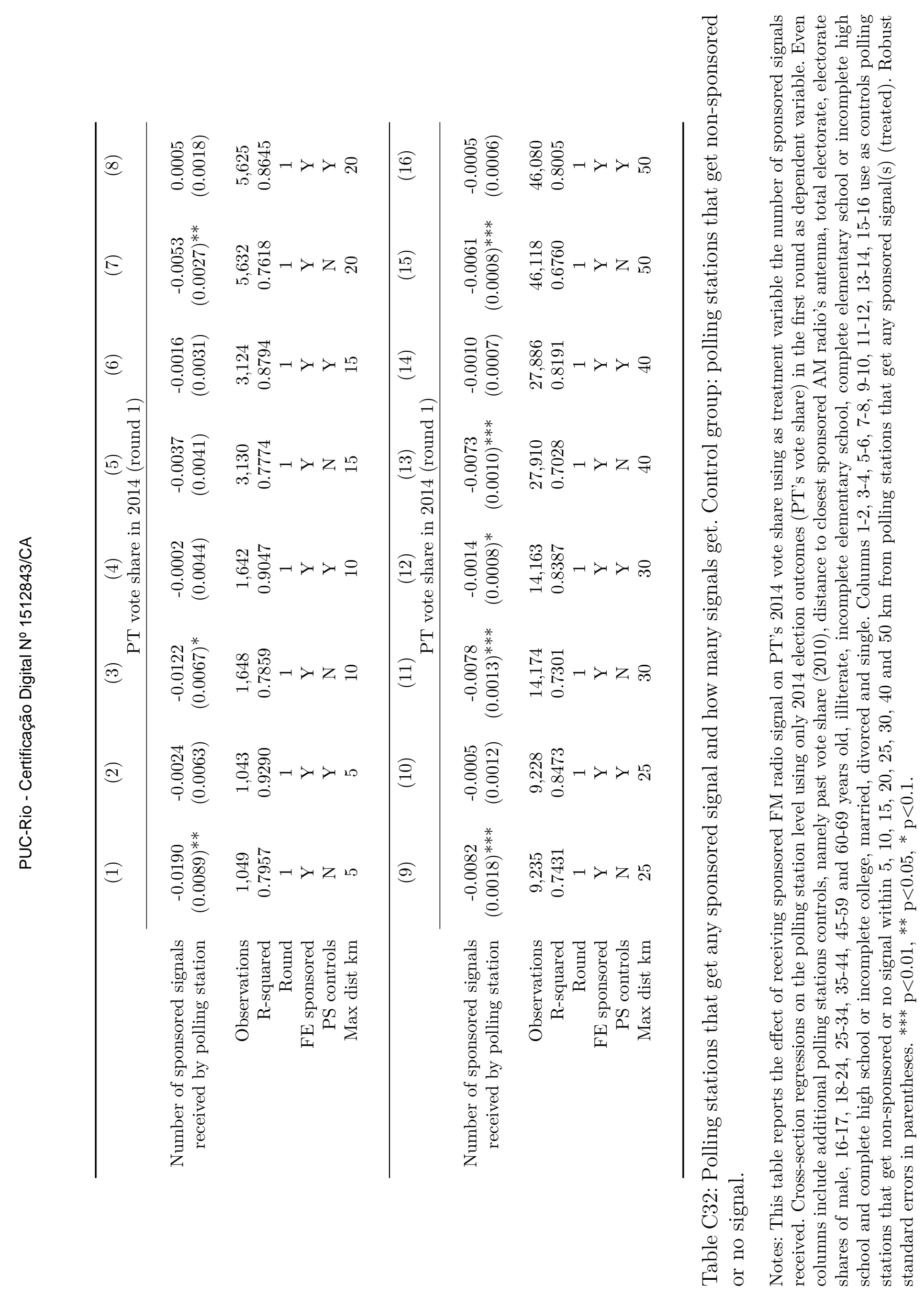




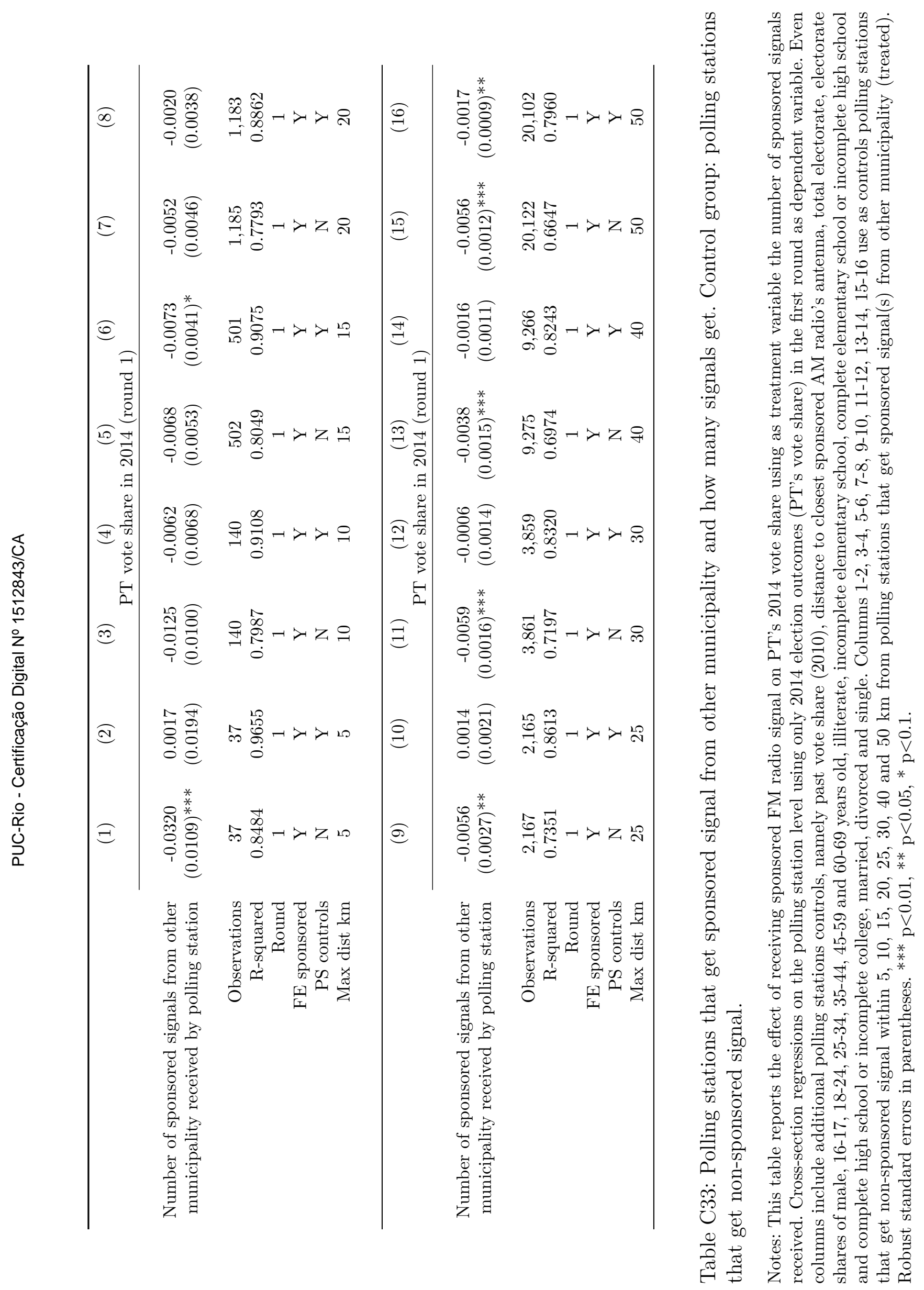




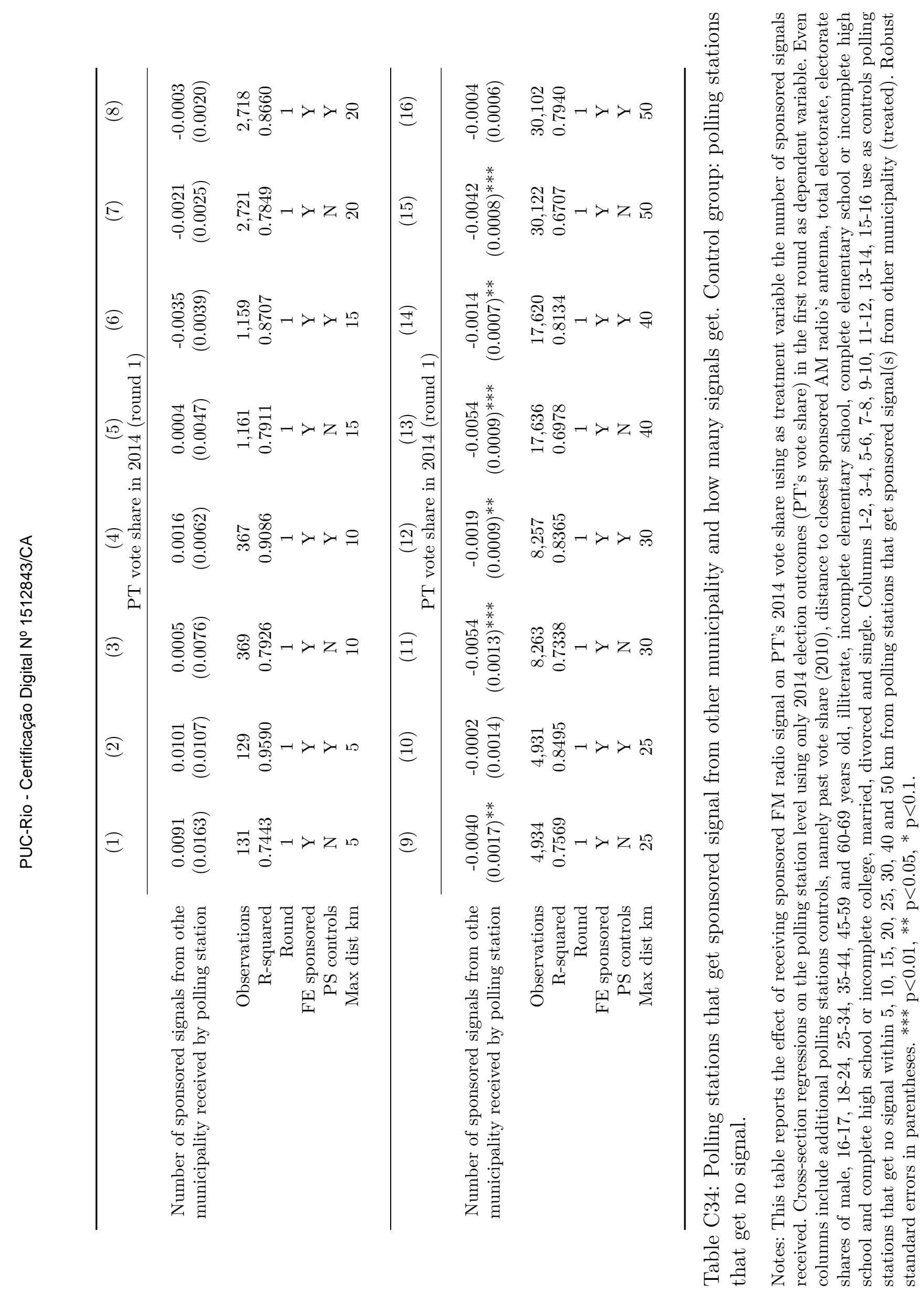




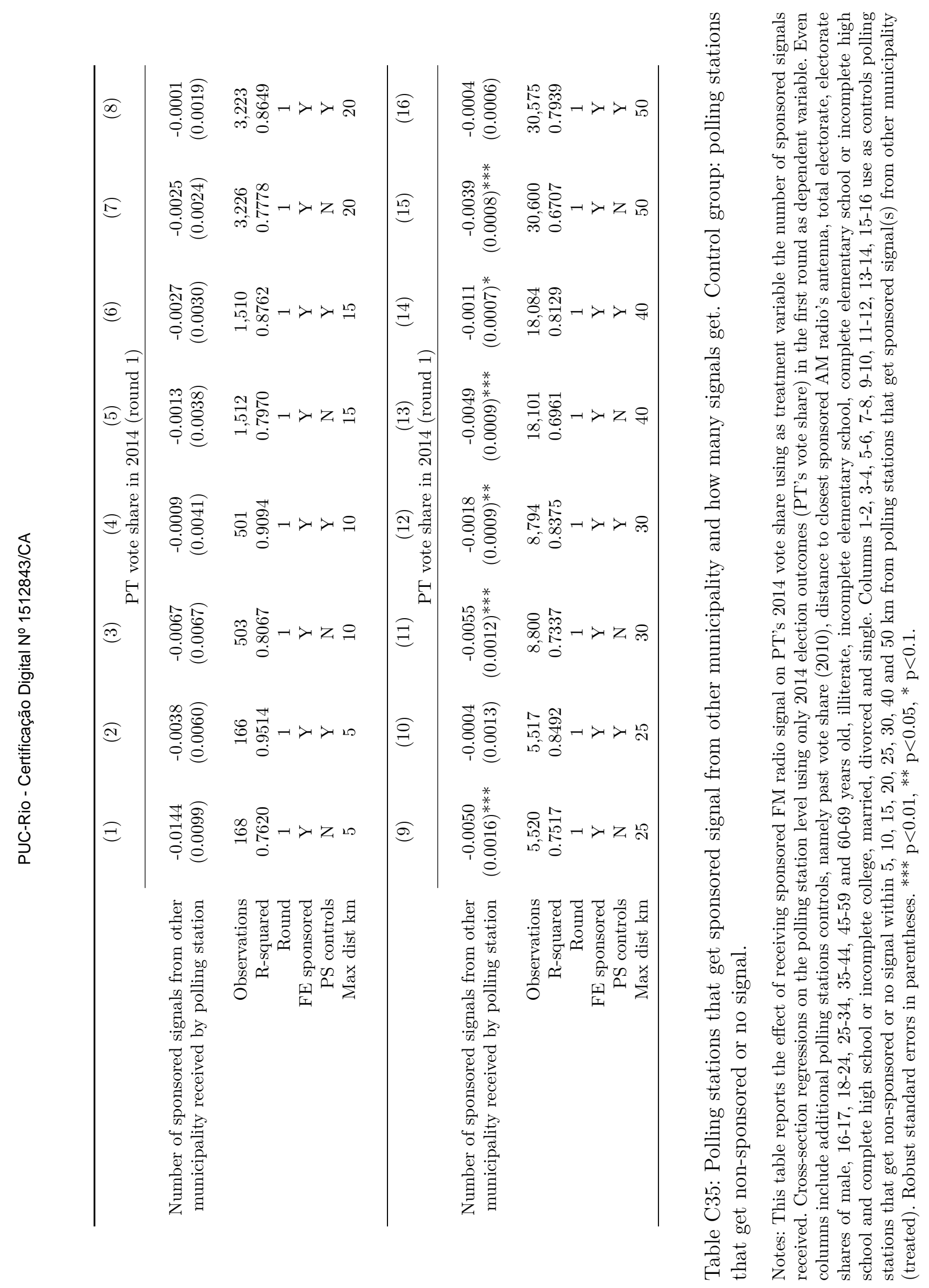




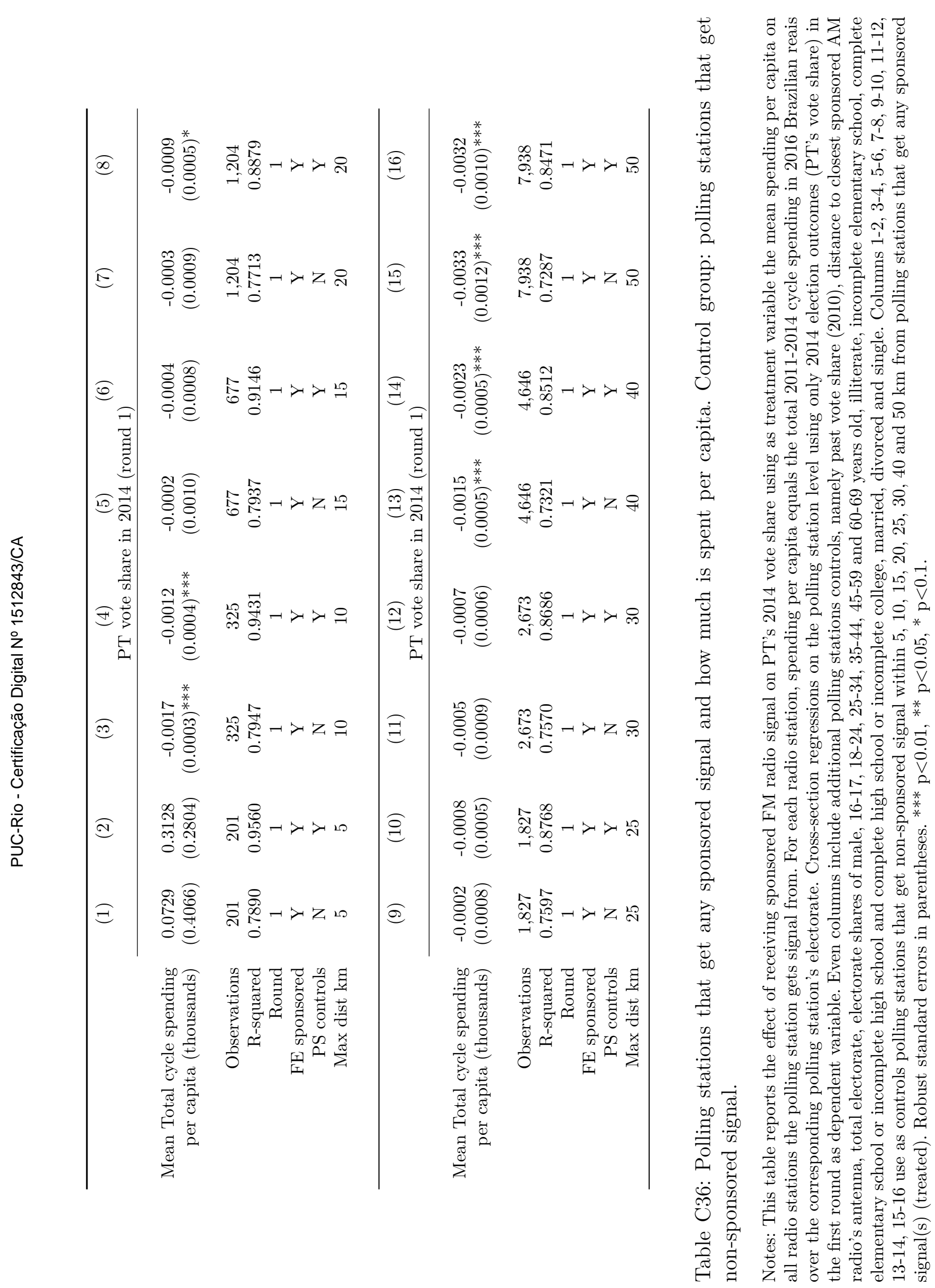




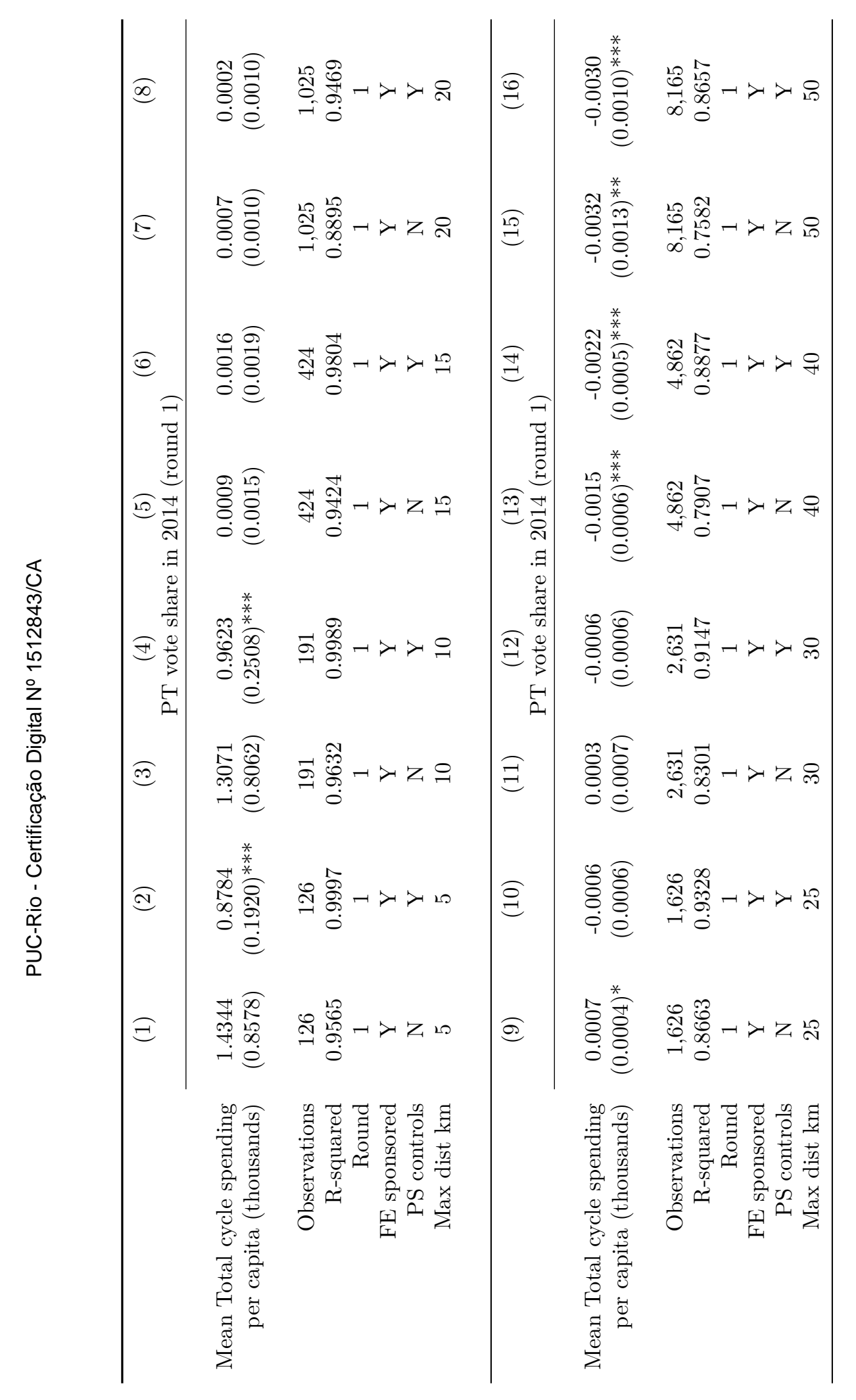

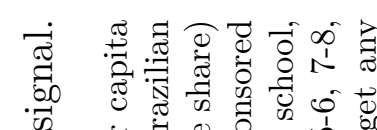

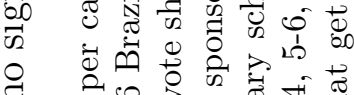

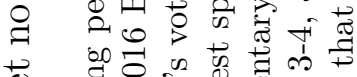

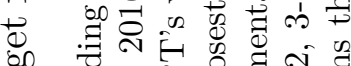

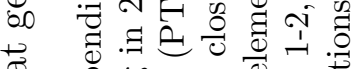

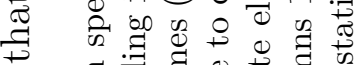

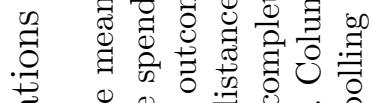

要

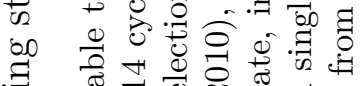

当

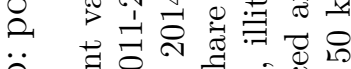

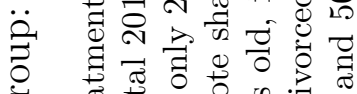

क人

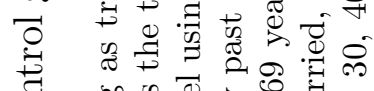

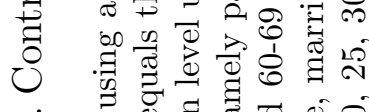

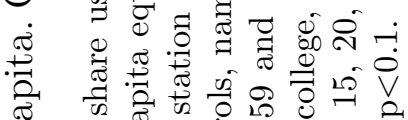

क्ष की

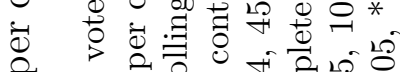

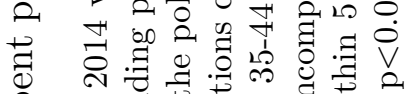

类

.

姜

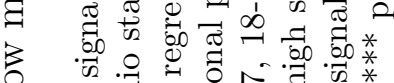

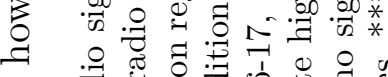

बే

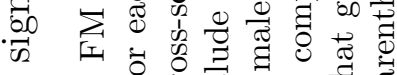

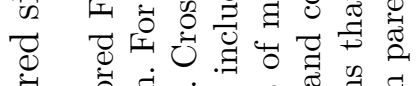

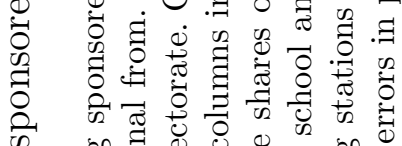

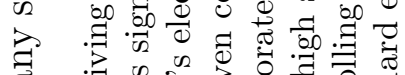

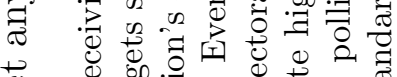

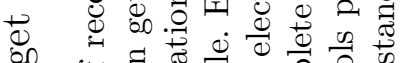

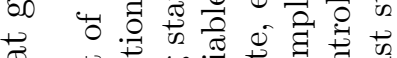

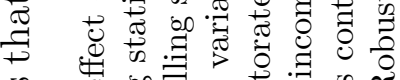

y 400

蛋

要

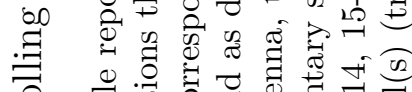

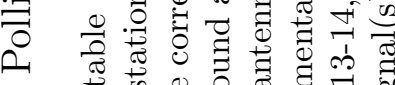

药

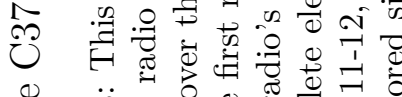

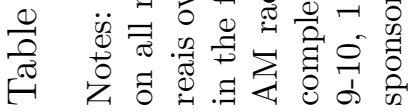




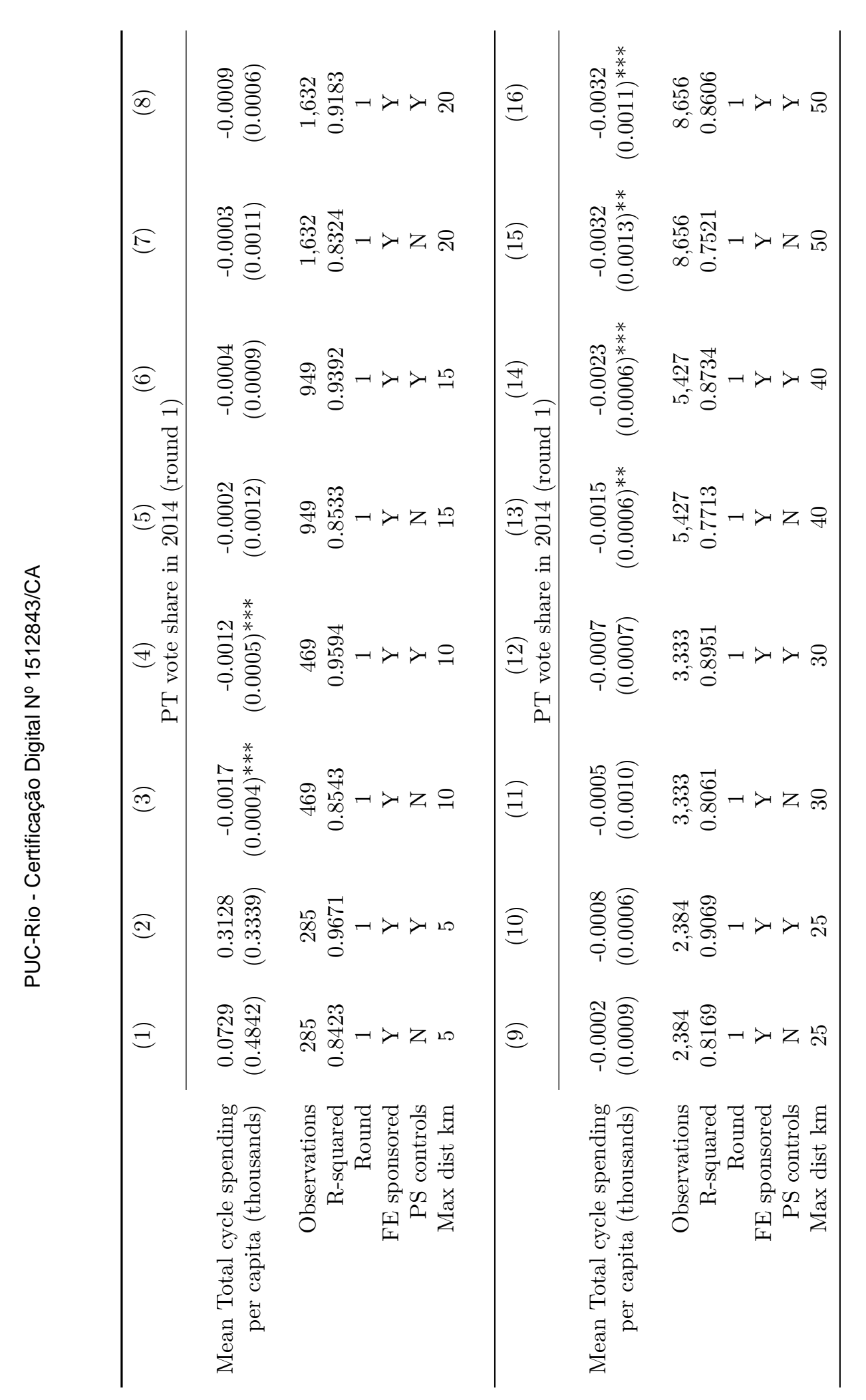

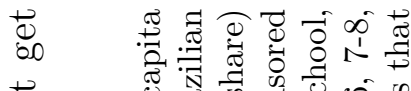

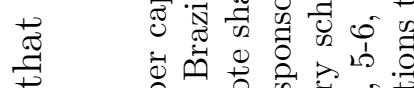

要

.

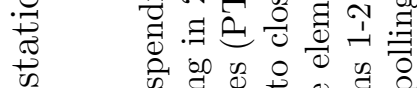

bo

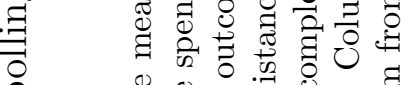

$\stackrel{2}{2} \quad 00$

$\ddot{0} \quad 0 \quad 0.000$

它

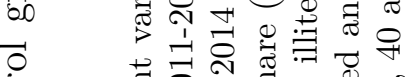

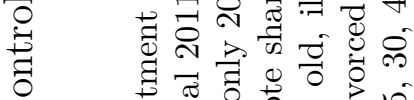

- 4 要

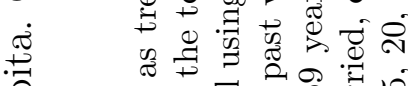

莍

- 它

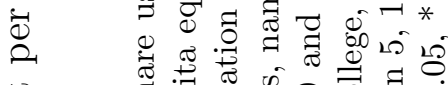

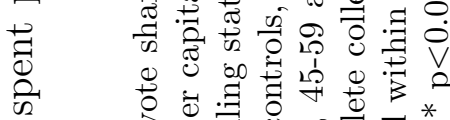

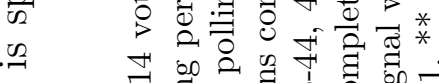

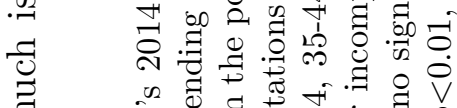

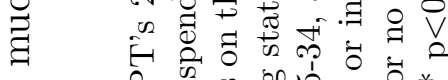

每 $\quad$ o.

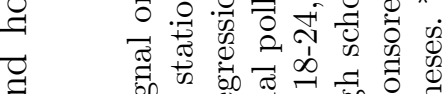

สี की

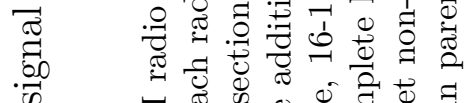

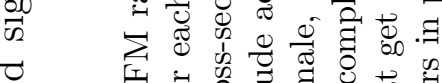

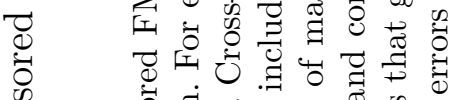

告

की की

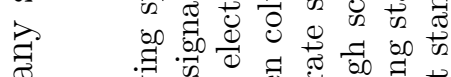

ब $\quad 50$

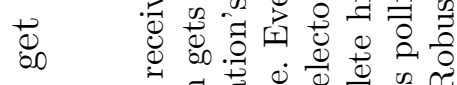

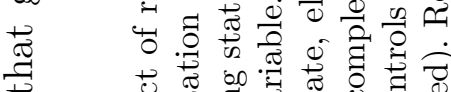

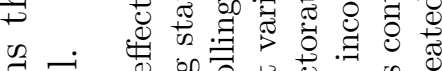

总焉

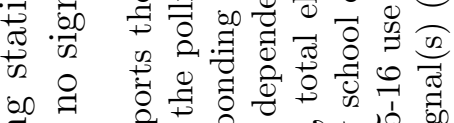

范象

○.

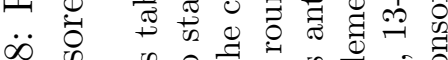

$\ddot{\infty}$ on 0

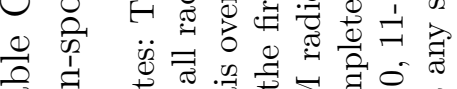

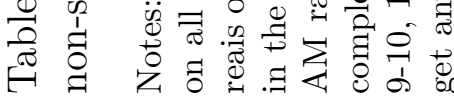




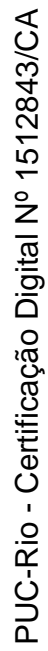

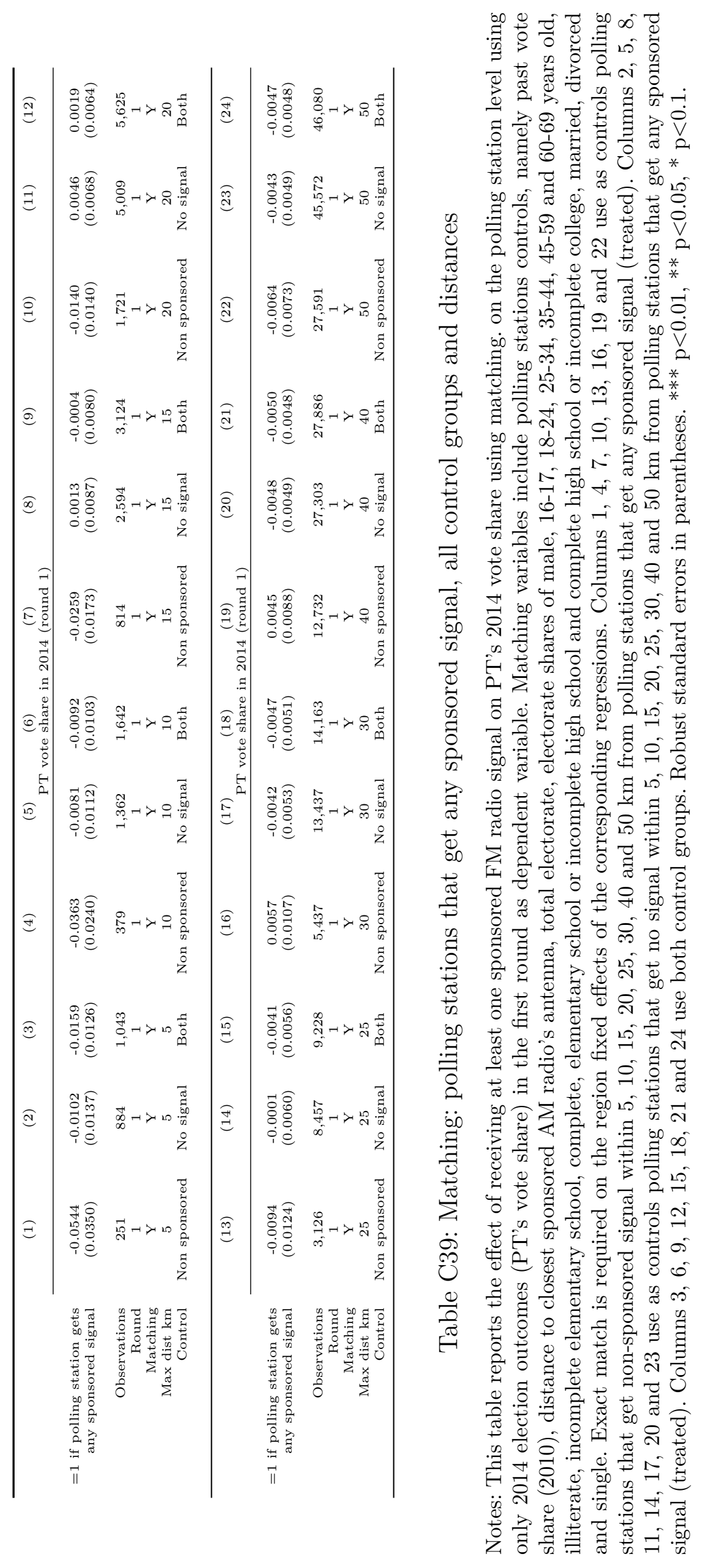




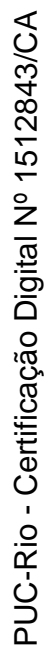

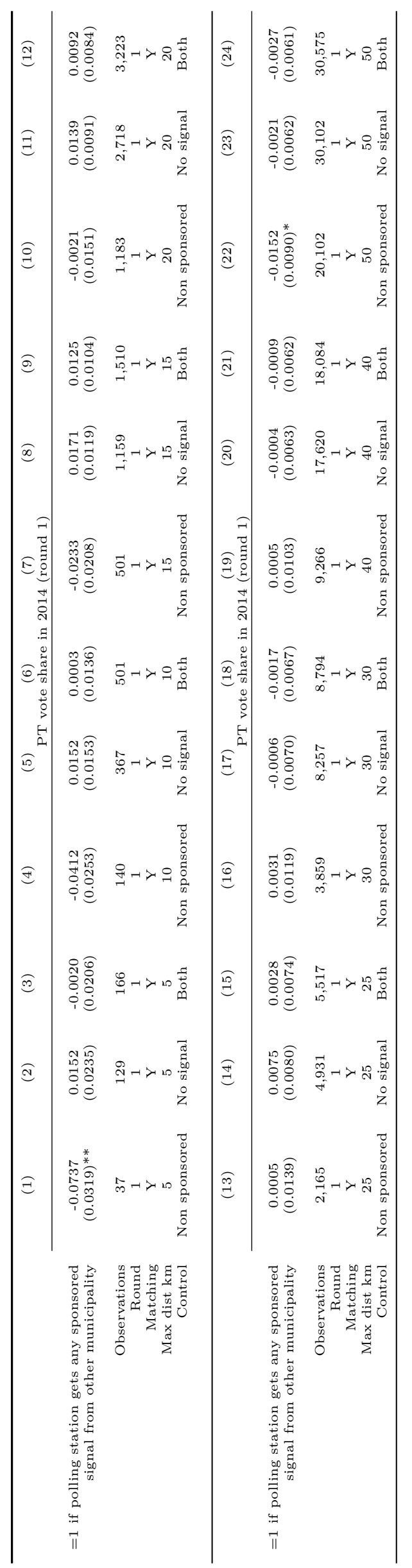

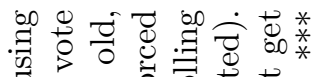

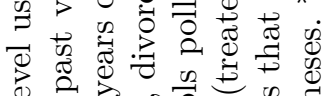

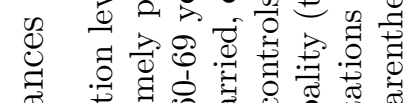

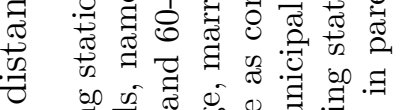

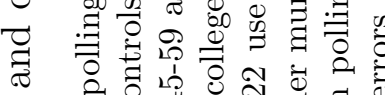

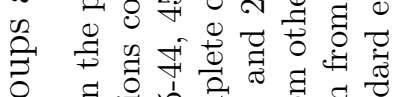

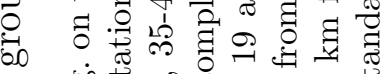

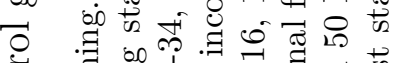

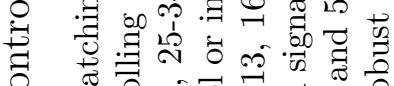

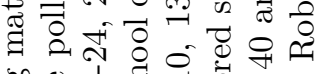
零

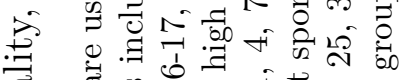

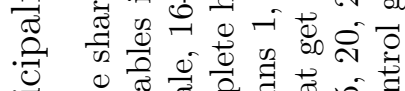

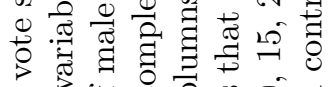
荘 ¿

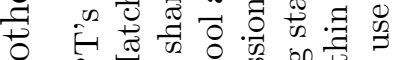

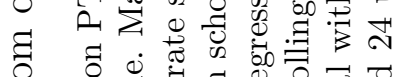
‡ శี . क

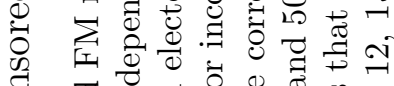

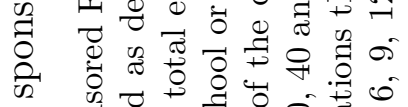
की

$\infty$ की

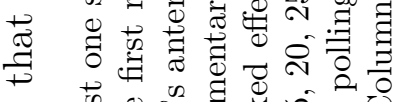

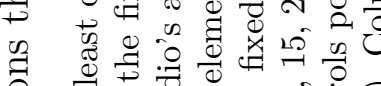

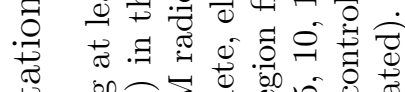
要

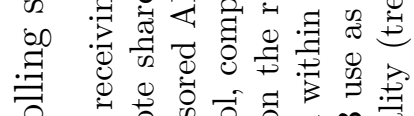
范

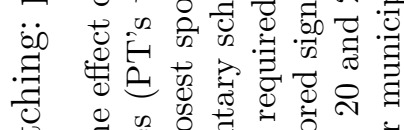

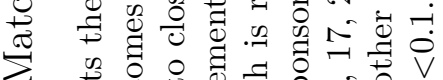

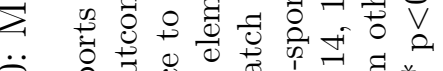
单

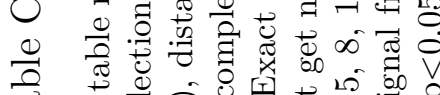

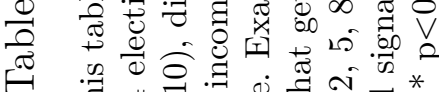

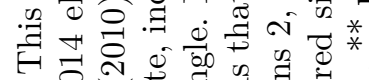
स.

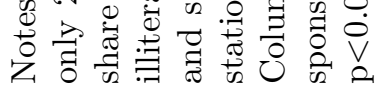

